Doktori értekezés

\title{
FOTOSZINTETIKUS RENDSZEREK BIOKOMPOZITOKBAN
}

\author{
Hajdu Kata \\ Témavezetö: Dr. Nagy László
}

Szegedi Tudományegyetem

Orvosi Fizikai és Orvosi Informatikai Intézet

Fizika Doktori Iskola

Szeged, 2014. 


\section{Tartalom}

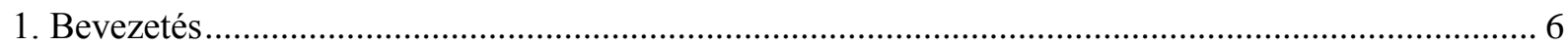

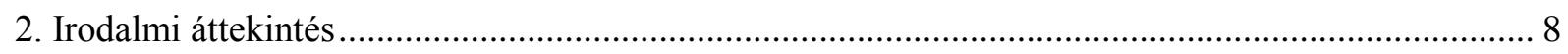

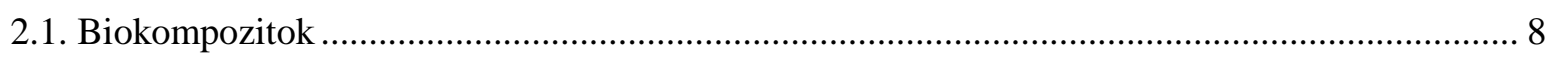

2.2. Fényenergia-átalakítás fotoszintetikus rendszerekben ...................................................... 10

2.3. A fotoszintetikus reakciócentrum szerkezete és müködése....................................................... 11

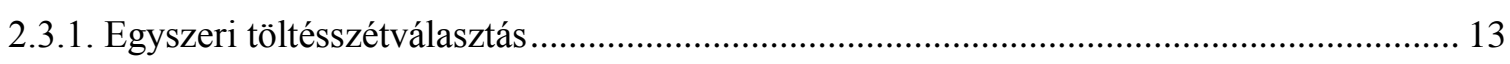

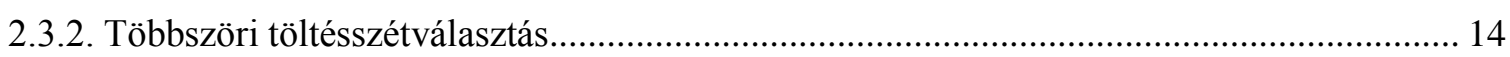

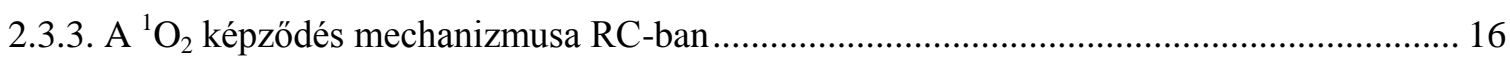

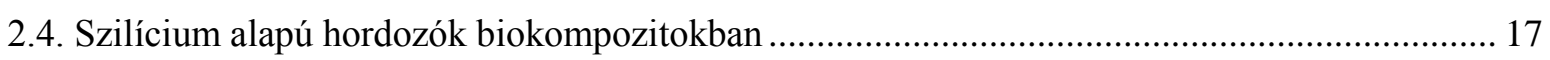

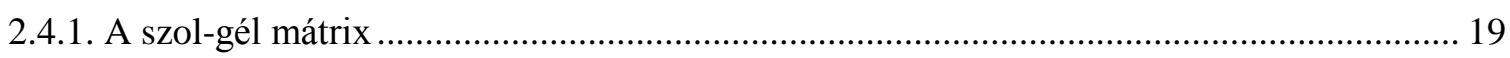

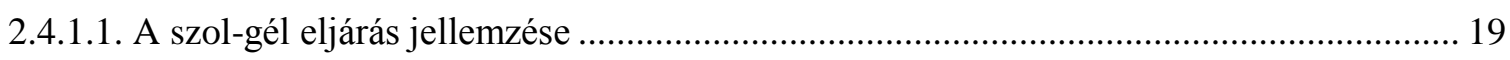

2.4.1.2. Biológiai anyagok rögzítése szol-gél módszerrel ......................................................... 19

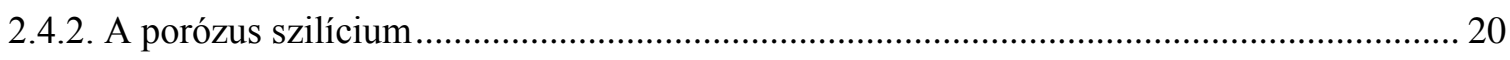

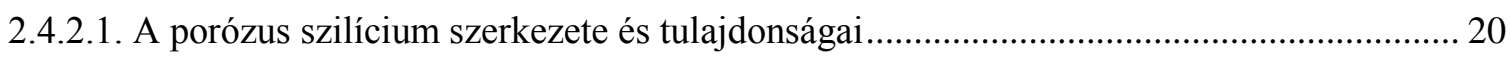

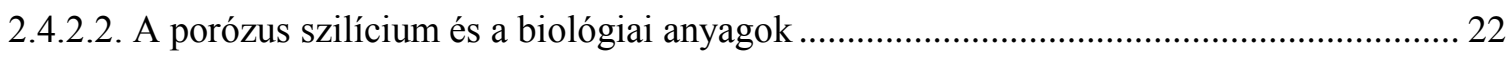

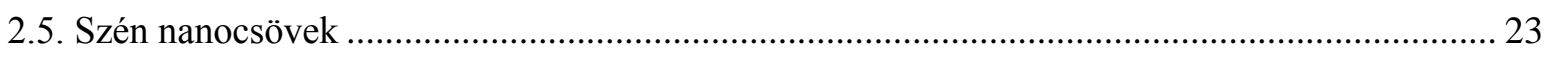

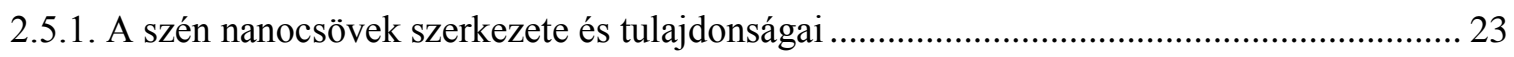

2.5.2. A szén nanocsövek és a biológiai anyagok közötti kölcsönhatás........................................ 25

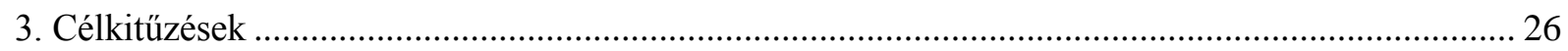

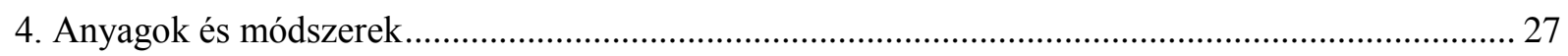

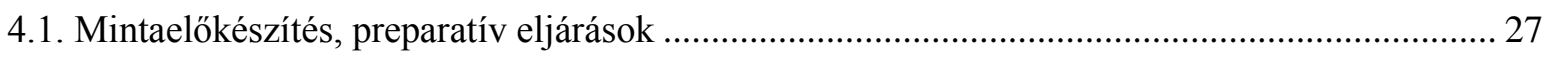

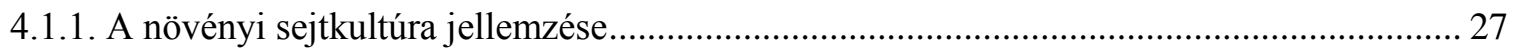

4.1.2. A Rhodobacter sphaeroides baktériumtörzs tenyésztése .................................................. 27

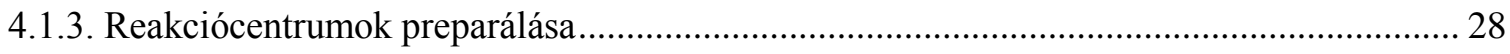

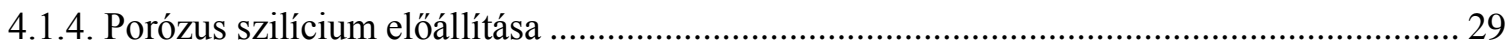

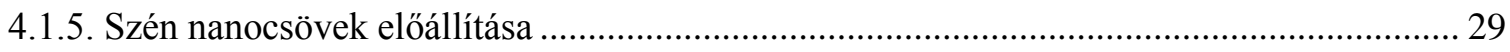

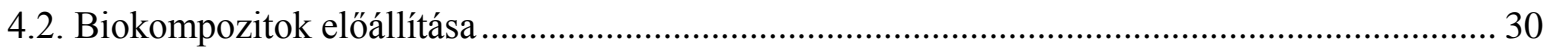

4.2.1. Növényi sejtek rögzítése szol-gél módszerrel ................................................................... 30

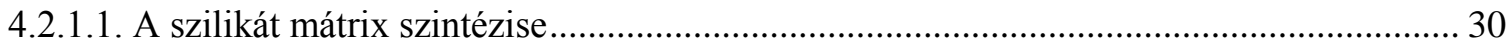

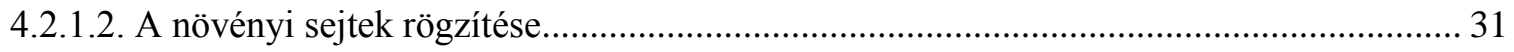

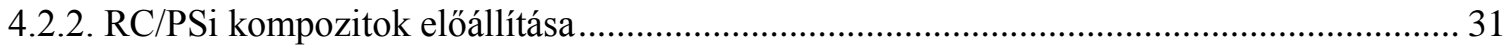

4.2.3. Reakciócentrum/szén nanocső kompozitok előállítása ....................................................... 33

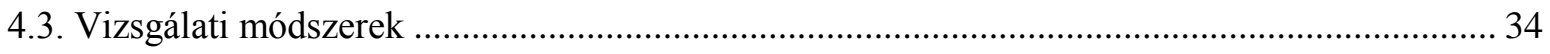

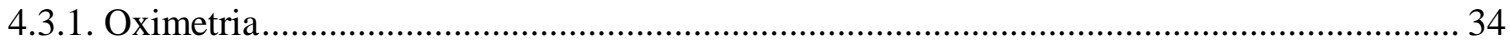


4.3.3. A fotokémiai/-fizikai aktivitás meghatározása abszorpcióváltozás kinetikai mérésével..... 35

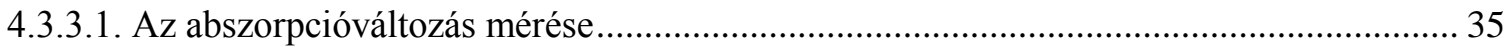

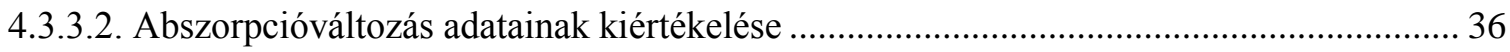

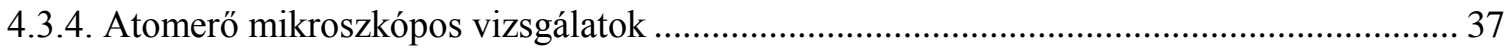

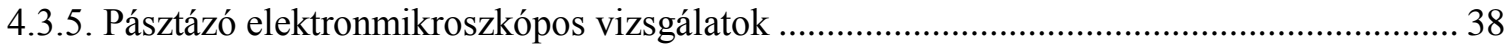

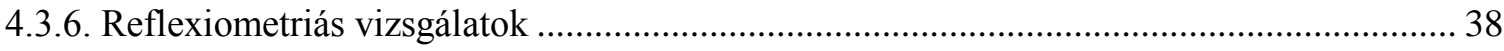

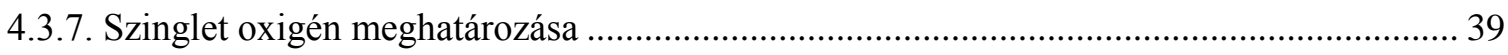

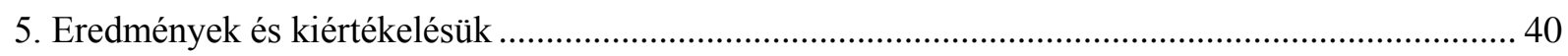

5.1. Egész növényi sejtekkel létrehozott kompozitok jellemzése ................................................... 40

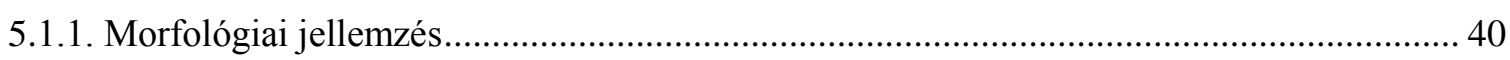

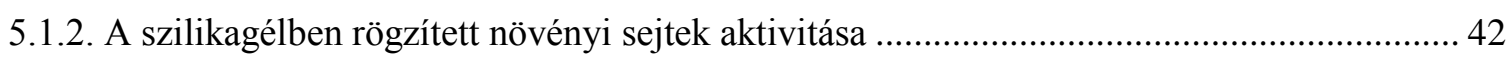

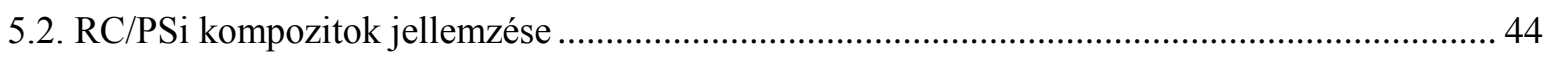

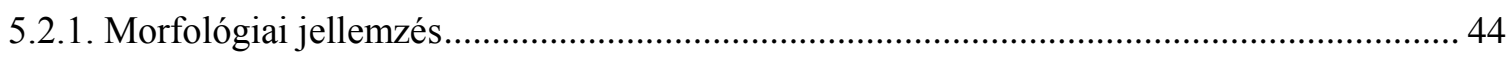

5.2.2. A RC PSi struktúrába történő beépülésének optikai vizsgálata......................................... 47

5.2.3. PSi-hez kötött reakciócentrum fotokémiai/-fizikai aktivitása ................................................ 50

5.2.3.1. Töltésszétválasztás egyetlen telítési fénygerjesztést követően ........................................ 50

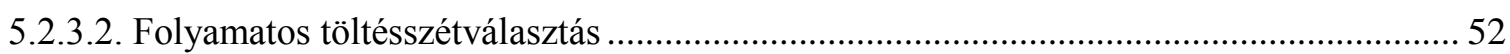

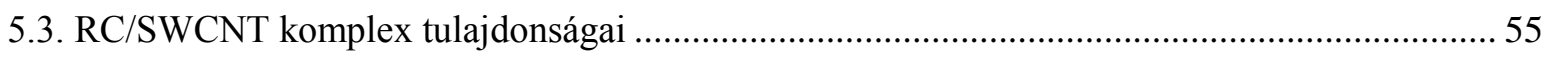

5.3.1. A RC/SWCNT komplexek morfológiai jellemzése ................................................................ 56

5.3.2. Az egyfalú szén nanocsövön rögzített reakciócentrum aktivitása ......................................... 58

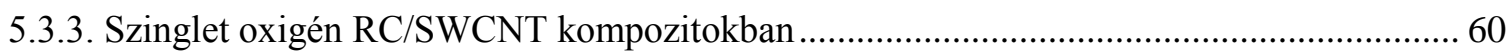

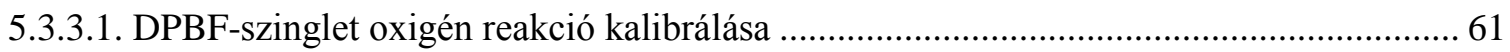

5.3.3.2. A szinglet oxigén egyensúlyi mennyisége szén nanocsövek jelenlétében ........................ 62

5.3.3.3. A RC fotociklusa során keletkezett szinglet oxigén kimutatása DPBF-fel ....................... 64

5.3.3.4. Szinglet oxigén a RC/szén nanocső rendszerben ........................................................... 67

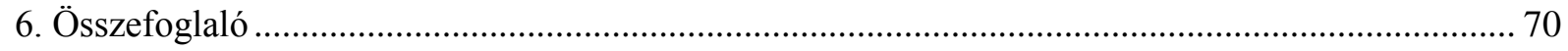

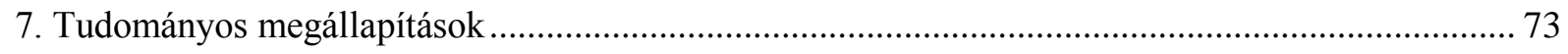

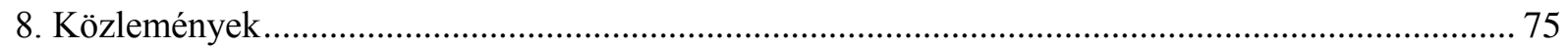

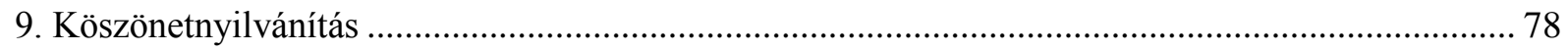

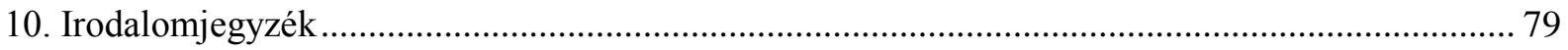

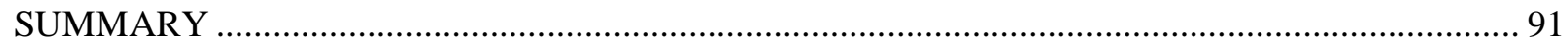




\section{Rövidítések jegyzéke}

\begin{tabular}{|c|c|}
\hline AFM & atomierő mikroszkóp \\
\hline APTES & 3-aminopropil-trietoxiszilán \\
\hline ATP & adenozin-trifoszfát \\
\hline BChl & bakterioklorofill monomer \\
\hline${ }^{1} \mathrm{Bchl}^{*},{ }^{3} \mathrm{Bchl}{ }^{*}$ & 1* $\quad$ szinglet és triplet állapotú $\mathrm{BChl}$ \\
\hline BPheo & bakteriofeofitin monomer \\
\hline CNT & szén nanocső \\
\hline DPBF & 1,3-difenilizobenzofurán \\
\hline DBB & o-dibenzoilbenzén \\
\hline EDX & energia diszperzív röntgensugár spektroszkópia \\
\hline FTIR & Fourier transzformációs infravörös spektroszkópia \\
\hline GTA & glutáraldehid \\
\hline$\Delta G$ & Gibbs-féle szabadenergia-változás \\
\hline$\Delta H$ & entalpia-változás \\
\hline$\Delta S$ & entrópia-változás \\
\hline EM & elektronmikroszkóp \\
\hline $\mathrm{Fe}^{2+}$ & vas(II)-ion (nem-hemtípusú vas) \\
\hline ISC & szinglett-triplet átmenet (Inter System Crossing) \\
\hline$k_{\mathrm{AP}}$ & a $\mathrm{P}^{+} \mathrm{Q}_{\mathrm{A}}{ }^{-} \rightarrow \mathrm{PQ}_{\mathrm{A}}$ töltésrekombináció sebességi állandója \\
\hline$k_{\mathrm{BP}}$ & a $\mathrm{P}^{+} \mathrm{Q}_{\mathrm{B}}{ }^{-} \rightarrow \mathrm{PQ}_{\mathrm{B}}$ töltésrekombináció sebességi állandója \\
\hline
\end{tabular}




\begin{tabular}{|c|c|}
\hline$K_{\mathrm{AB}}$ & kinonok közötti első elektrontranszfer egyensúlyi állandója \\
\hline LDAO & $\mathrm{N}, \mathrm{N}$-dimetil-dodecilamin-N-oxid, Laurildimetilamin-N-oxid \\
\hline $\mathrm{L}, \mathrm{M}, \mathrm{H}$ & a bakteriális reakciócentrum fehérje alegységei (light, middle, heavy) \\
\hline MS & Murashige és Skoog növekedést serkentő táptalaj \\
\hline MTGS & metil-triglicerol-szilán \\
\hline MWCNT & többfalú szén nanocső \\
\hline OD & optikai denzitás \\
\hline PBS & foszfát pufferolt fiziológiás sóoldat \\
\hline PBST & foszfát pufferolt fiziológiás sóoldat, 0,1\% Tween 20 \\
\hline PSi & porózus szilícium \\
\hline PSI & a növények és cianobaktériumok első fotokémiai rendszere \\
\hline PSII & a növények és cianobaktériumok második fotokémiai rendszere \\
\hline $\mathrm{Q}_{\mathrm{A}}$ & elsődleges vagy primer kinon, első stabil elektron akceptor \\
\hline $\mathrm{Q}_{\mathrm{B}}$ & másodlagos vagy szekunder kinon, másodlagos elektron akceptor \\
\hline $\mathrm{QH}_{2}$ & dihidro-kinon, kinol \\
\hline $\mathrm{UQ}_{10}$ & ubikinon-10, 2,3-dimetoxi-5-metil-6-kaizoprenol-p-benzokinon \\
\hline$R b$. & Rhodobacter \\
\hline $\mathrm{RC}$ & fotoszintetikus reakciócentrum fehérje \\
\hline RMS & Root Mean Square, érdesség \\
\hline NAA & a-naftalén ecetsav \\
\hline NADP & nikotinamid-adenin-dinukleotid-foszfát \\
\hline $\mathrm{NaSi}$ & nátrium-szilikát \\
\hline
\end{tabular}


SPGLSLVSHMQT peptid molekula aminosav sorrendje (S: szerin, P: prolin, G:

glicin, L: leucin, V: valin, H: hisztidin, M: metionin, Q: glutamin, T: treonin )

SWCNT egyfalú szén nanocső

SWCNT/RC egyfalú szén nanocsö/reakciócentrum fehérje bio-nanokompozit komplex

SEM pásztázó elektronmikroszkóp

$\mathrm{P}, \mathrm{P}^{+}, \mathrm{P}^{*} \quad$ alapállapotú, oxidált, gerjesztett bakterioklorofill dimer, elsődleges, vagy primer donor

TL TL-puffer (10 mM TRIS, $100 \mathrm{mM} \mathrm{NaCl,} 0.03 \%$ LDAO, pH 8,0)

TRIS 2-amino-2-hidroximetil-1,3-propándiol 


\section{Bevezetés}

A természet által évmilliók alatt kifejlesztett és tökéletesített élő rendszerek utánozhatatlan pontossággal képesek elvégezni a létfenntartó folyamataikat. Müködésük a biológiai szerveződés bármely szintjén rendkívül specifikus, érzékeny és hatékony. Számos kutatás foglalkozik a biológiai anyagok jobb megismerésével, hiszen az egyes biológiai mechanizmusokat felfedezve és megértve nem csak a természet kreativitására lehet rácsodálkozni, hanem új ötletek és felhasználási lehetőségek tárháza is megnyílik előttünk.

Vitathatatlan, hogy a földi élet kialakulásában és jelenlegi formájának fenntartásában a fény különösen fontos szerepet játszik. Az élő szervezetekben több folyamat is kapcsolódik a fényenergia átalakításához, mint például a látás, a növények morfológiai szabályozásáért felelős fitokrómrendszer müködése, de talán az egyik legfontosabb a fotoszintézis folyamata. A fényenergia kémiai energiává alakítása nélkül nem jöhetett volna létre a földi élet jelenlegi formája. A földi bioszféra kialakulásának és fenntartásának is alapja a napenergia, amelynek leghatékonyabb átalakítását a fotoszintetizáló szervezetek végzik.

A fotoszintézis igen összetett folyamat. Máig nem ismerjük minden részletét azoknak a lépéseknek, melyek végül a fény energiájának felhasználásával lehetővé teszik szerves anyag szervetlenből való előállítását. A fotoszintéziskutatások során egész növényi vagy bakteriális sejteket és ezekből kinyert sejtalkotókat, sőt, molekulákat egyaránt vizsgálnak. Ezek a biológiai rendszerek azonban csak természetes környezetükben müködnek nagy hatékonysággal, a külső változásokra igen érzékenyen reagálnak. Ha mesterséges körülmények között szeretnénk őket vizsgálni, megfelelő környezetet kell számukra biztosítani.

Napjainkban különös figyelem fordul az ún. (bio)kompozit anyagokra, melyekben lehetséges olyan jól szabályozott környezetet biztosítani a vizsgálni kívánt biológiai anyagnak, amely mellett idegen környezetben is jól megőrzi aktivitását. Általában egy „biokompatibilis” (biológiai anyagot nem károsító) szerves vagy szervetlen hordozón rögzítik a választott sejtet, sejtrészletet, vagy biomolekulát. Az így létrehozott összetett rendszerek a rögzített (immobilizált) anyagtól és hordozótól függően számos területen felhasználásra kerülhetnek, 
többek között az orvostudományban, a talaj-, és víztisztításban, a bioelektronikában és különféle bioszenzorok kifejlesztésében.

Munkám során fénnyel gerjeszthető biokompozit anyagok előállításával és karakterizálásával foglalkoztam. A hibrid anyagok „biológiai komponensei” különböző fotoszintetikus rendszerek (egész sejtek és tisztított fehérjekomplexek), a szervetlen hordozó komponensek pedig szén alapú (szén nanocső) vagy szilícium származékok (szilikagél, porózus szilícium) voltak. Kezdetben egész növényi sejteket rögzítettem szilikagélben és az így létrejött kompozit fotoszintetikus aktivitását jellemeztem (Université de Namur, FUNDP, Prof. Bao Lian Su laboratóriuma). A biokompozitokkal kapcsolatos munkát Szegeden is tudtam folytatni a Szegedi Tudományegyem Orvosi Fizikai és Orvosi Informatikai Intézetében, Dr. Nagy László témavezetésével. Kutatócsoportunk elsősorban bíborbaktériumokból tisztított fotoszintetikus reakciócentrum fehérjék (RC) felhasználásával készít nanokompozitokat, és azok szerkezeti és müködési paramétereit jellemzi, illetve a lehetséges gyakorlati alkalmazásokat vizsgálja.

A Rhodobacter $(R b$.$) sphaeroides bíborbaktérium RC-a egyike a legjobban$ tanulmányozott fehérje-komplexeknek. Közel 100\%-os hatékonysággal alakítja át a fényenergiát kémiai energiává fényindukált redox folyamatok által. Minden egyes elnyelt foton gerjeszti a fehérje-komplex egy speciális klorofill dimerjét. Ez a fotoszintézis első lépése, amely minimális energiaveszteséggel történik. A fehérje az izolálást és tisztítást követően is hosszú ideig képes megőrizni a fotokémiai/-fizikai aktivitását. Előnyös tulajdonságaiból adódóan kiváló jelölt a fényenergia hasznosítás céljából történő tudományos kutatásokra. Vezető, félvezető hordozóanyaggal kialakított biokompozitban lehetőség nyílik az igen gyors (fs-ms-os ) elektronátmenetek felhasználására különféle redox reakciókban.

A létrehozott bio-nanokompozitoknak elsősorban az optikai és az elektrokémiai tulajdonságait vizsgáltam. 


\section{Irodalmi áttekintés}

\subsection{Biokompozitok}

A fizika, informatika (modern (opto-)elektronika, lézertechnika, számításés információtechnika, stb.), valamint a biológia (elsősorban a molekuláris biológia és géntechnológia) közelmúltban elért eredményei az anyag- és mérnöktudományokban is új lehetőségeket nyitottak. A nanotechnológia eszközeivel a kutatók képessé váltak a biológiai rendszerek müködésének beható tanulmányozására, jobb megértésére és olyan rendszerek kikísérletezésére, melyekbe átültethetőek a természet által évmilliók alatt tökéletesített biológiai rendszerek müködési elvei.

Az élővilág számos ötletet kölcsönzött már a tudománynak. Jó példa erre többek között a lótuszlevél szuperhidrofób felszíne (Barthlott és mtsai., 1997), a kovamoszatok, melyek szilíciumvázat alakítanak ki maguk körül, így védekezve a külső káros behatásoktól, vagy a pillangók szárnya, amelyeket mintázva speciális fotonikus struktúrák hozhatók létre (Velev és mtsai., 1997; Wijnhoven, 1998).

Ezek a biológiai rendszerek igen hatékonyan és pontosan müködnek, nagy specifitással, finoman kidolgozott módon. Természetes környezetükből kiszakítva viszont sérülékenyek, érzékenyek a külső hatásokra. Mesterséges körülmények között müködésük optimalizálásához megfelelö környezet szükséges, melyre jó megoldás kompozit anyagok létrehozása.

Kompozitokról akkor beszélünk, amikor eltérő tulajdonságokkal rendelkező anyagokat társítunk. Az ilyen összetett rendszerekben a két - vagy többfajta anyag előnyös tulajdonságai egy időben hasznosíthatóak, azok sokszor fel is erősíthetik egymást, vagy akár új tulajdonságok is megjelenhetnek. Biokompozitok esetében legalább az egyik alkotó biológiai eredetű, míg bio-nanokompozitokról akkor beszélünk, ha a kompozit legalább egyik alkotóeleme - a hordozó vagy a bezárt biológiai anyag - legalább az egyik dimenzióban nano-méretü.

Leggyakrabban a biológiai anyagot helyezzük egy választott biokompatibilis hordozó anyagra, amelynek az a funkciója, hogy megfelelö körülményeket biztosítson a választott biológiai anyag számára, és elősegítse 
annak hatékony felhasználását egyéb rendszerekben. Ezekben az összetett rendszerekben könnyebben szabályozhatóak a környezeti paraméterek, beállítható többek között a kívánt hőmérséklet, $\mathrm{pH}$, illetve reagensek, metabolitok, stb. mennyisége. Amennyiben a létrehozott kompozitban a mátrix anyag vázként is funkcionál a biológiai anyag számára, akkor a fizikai behatásoktól is védelmet jelenthet.

A biokompozitok létrehozása során számos biológiai anyagot sikerrel rögzítettek már szervetlen hordozó felületén. Az egyes biológiai szerveződések különböző előnyös tulajdonságokkal bírnak, így a felhasználásuk is sokféle lehet. Megemlítendőek a különböző mikroorganizmusok, mint a gombák, a baktériumok és a mikroalgák, amelyek számos területen hasznosíthatóak, akár ipari méretekben is. Biotechnológiai alkalmazásuk igen széleskörü, hiszen sokféle anyagcseretermék előállítására képesek például a mezőgazdaság, élelmiszertechnológia vagy gyógyszergyártás területén. Környezetvédelmi szempontból fontos alkalmazási lehetőségük a talaj - és víztisztítási képességük, hiszen egyes mikroorganizmusok nagyon hatékonyan bontanak (vagy kötnek meg) bizonyos, egyébként nehezen eltávolítható szennyeződéseket (pl. olajat, nehézfémeket). Az ilyen biokompozitok nagyban elősegíthetik és felgyorsíthatják a káros anyagok (bio)degradációját (Rehm és mtsai., 1996).

Kitüntetett figyelemmel fordulnak a kutatók a fénnyel gerjeszthető, így a fotoszintetikus szervezetek szervetlen rendszerekhez való rögzítése felé is, egész sejtektől molekuláris szintig egyaránt. Az alap- és alkalmazott kutatások fontos területe a fotoszintetizáló anyagok természetes környezetükön kívül történő tanulmányozása. Minden olyan információ, amelyet a fényenergia kémiai energiává történő átalakításából nyerhetünk, fontos üzenetet hordozhat számos alkalmazási terület, pl. az energetika, az élelmiszeripar és a környezetvédelem számára.

Egész növényi és bakteriális sejtekböl (Oda és mtsai., 2010; Meuner és mtsai., 2010), membránrészekből (ún. tilakoidokból) (Meuner és mtsai., 2009), különféle fotokémiai rendszerekből (Nassif és mtsai., 2002) egyaránt létrehoztak már biokompozitokat. Hatékony alkalmazásukra jó példa, hogy spenótból kinyert kloroplasztisz és tilakoid szuszpenziók is jól felhasználhatóak különböző herbicidek (pl. terbutrin, atrazin, diuron), vagy higany és réz optikai detektálására (Campas és mtsai., 2008; Ventrella és mtsai., 2009, 2010). 
Állandó, stabil körülményeket biztosítva a fotoszintetizáló anyagoknak, lehetőség nyílik mesterséges körülmények között felhasználni a fényenergiát. Ily módon lehetségessé válhat ún. „újgenerációs” eszközökben való alkalmazásuk pl. az integrált optoelektronikában, a képalkotásban, illetve bioszenzorok és energiaátalakító rendszerek létrehozásában.

\subsection{Fényenergia-átalakítás fotoszintetikus rendszerekben}

A földi élet jelenlegi formájának kialakulásához és fenntartásához nélkülözhetetlenek voltak a fotoszintetizáló élőlények. Megközelítőleg 400 millió éve az oxigéntermelő fotoszintézis megjelenése által válhatott a Föld légköre oxidatív tulajdonságúvá, és jöhetett létre az ózonréteg, amely később lehetővé tette az élet jelenlegi formájának kialakulását. Az atmoszférikus oxigén biztosításán kívül a fotoszintézis másik jelentősége a szén-dioxid megkötése. A fotoszintézis ún. sötétszakaszában végbemenő folyamat során a megkötött széndioxid szénhidrát szintig redukálódik. Ennek köszönhető többek között a véges mennyiségben rendelkezésünkre álló fosszilis energiahordozók keletkezése is.

A fényszakaszban a fény elnyeléséért fehérjékhez kötött pigmentmolekulák a felelősek, amelyek antenna rendszerekbe tömörülnek. Az antenna komplexek proteinvázhoz kötődve helyezkednek el a fotoszintetikus membránban. A pigmentek foton elnyelése után gerjesztett állapotba kerülnek, melynek energiája kisugárzódhat fluoreszcencia vagy hő formájában, illetve átadódhat szomszédos, alacsonyabb gerjesztési energiájú pigmentmolekulára, hogy később a fotoszintetikus reakciócentrumokhoz továbbítódjon. A legjellemzőbb pigmentmolekula a porfirinvázas klorofill, melynek első gerjesztett állapotához a spektrum vörös, míg másodikhoz a kék abszorpciós sávjában található fényelnyelés tartozik. Baktériumokban az adott klorofilltípus bakterioklorofill megfelelője található. A jobb fényelnyelést járulékos pigmentek, pl. a karotinoidok biztosítják, amelyek egyben a fénykárosodás ellen is védelmet jelentenek.

A gerjesztési energia a fotoszintetikus apparátusban minden esetben töltésszétválasztást eredményez. Ezt egy elektrontranszport követi, amin keresztül 
töltés-stabilizálódás jön létre, ez biztosítja a sötétben végbemenő biokémiai folyamatok feltételeit. Ezek a kezdeti lépések az ún. fotoszintetikus reakciócentrumban $(\mathrm{RC})$ játszódnak le, melyben több, membránt átérö, transzmembrán protein összehangolt müködése vesz részt. A fotoszintézisnek ez a része igen gyors, ns-os, vagy akár fs-os folyamatokból áll, és az energiaátalakítás igen hatékony. A fénygerjesztést követően nem csak elekton-, de protontranszport is történik a membrán két oldala között. Az így kialakuló pH grádiens energiájának bizonyos hányada biztosítja az ATP szintézist (Mitchel, 1972). Ezt követően a sötét szakaszban a fényszakasz végtermékeinek felhasználásával történik a szén-dioxid megkötése és redukálása (Blankenship, R. E., 2002).

\subsection{A fotoszintetikus reakciócentrum szerkezete és müködése}

A fényenergia kémiai energiává alakulásának legelső lépései az ún. fotoszintetikus reakciócentrumban (RC), egy membránba ágyazott pigmentprotein komplexben történnek. Bár egy nanoméretű protein komplexről beszélünk (kb. $10 \mathrm{~nm}$, Dorogi és mtsai., 2006), mégis a RC biztosítja az energiát az egész földi élethez, ezért a természet napelemének is szokták nevezni. Ez a protein fénygerjesztést követően egy vektoriális elektrontranszportot valósít meg a membrán két oldala között, létrehozva ezzel azt a magas redoxpotenciált, amellyel lehetségessé válik a szén redukálása. Ez egy energiaigényes folyamat, melynek energiaszükségletét a fény szabadenergiája biztosítja.

A hatékony töltésszétválasztást és stabilizálást specifikus strukturális és funkcionális feltételek biztosítják. Bár az élő szervezetekben többféle RC-típus alakult ki (a növényekben és a cianobaktériumokban egyes és kettes fotokémiai rendszerek (PS-I és PS-II), illetve a bíbor és zöld baktériumok reakciócentrumai (Allen és Williams, 1998)), feltehetően mind egy ősi monomer fehérjéből származnak, és a bennük végbemenő folyamatok alapvetően azonosak.

A főbb lépések minden RC-ban megegyeznek, tehát (a) specifikus pigmentek elektronjait gerjeszti az adott hullámhosszú fény; töltésszétválasztás és stabilizálódás történik; (c) a fehérjén belüli dielektrikum, a hidrogénkötések hálózata átrendeződik (beleértve specifikus aminosavak 
protonációját és deprotonácóját is); (d) fehérjén belüli konformációs mozgások történnek (beleértve a fényhez és sötéthez alkalmazkodott állapotok közötti átmeneteket és relaxációs folyamatokat is); (e) elektronátadási folyamatok történnek a fehérjén belüli kofaktorok és a környezet redoxrendszerei között (Nagy és mtsai., 2010).

A reakciócentrum legismertebb, talán leggyakrabban tanulmányozott fajtája a viszonylag egyszerübb felépítésü, nem oxigéntermelö, nem-kén típusú bíborbaktériumok reakciócentruma. A növényekkel és cianobaktériumokkal ellentétben a bíborbaktériumok csak egyféle fotokémiai rendszert tartalmaznak, amely a növények kettes fotokémiai rendszerének felépítésével mutat nagymértékü hasonlóságot (1. ábra).

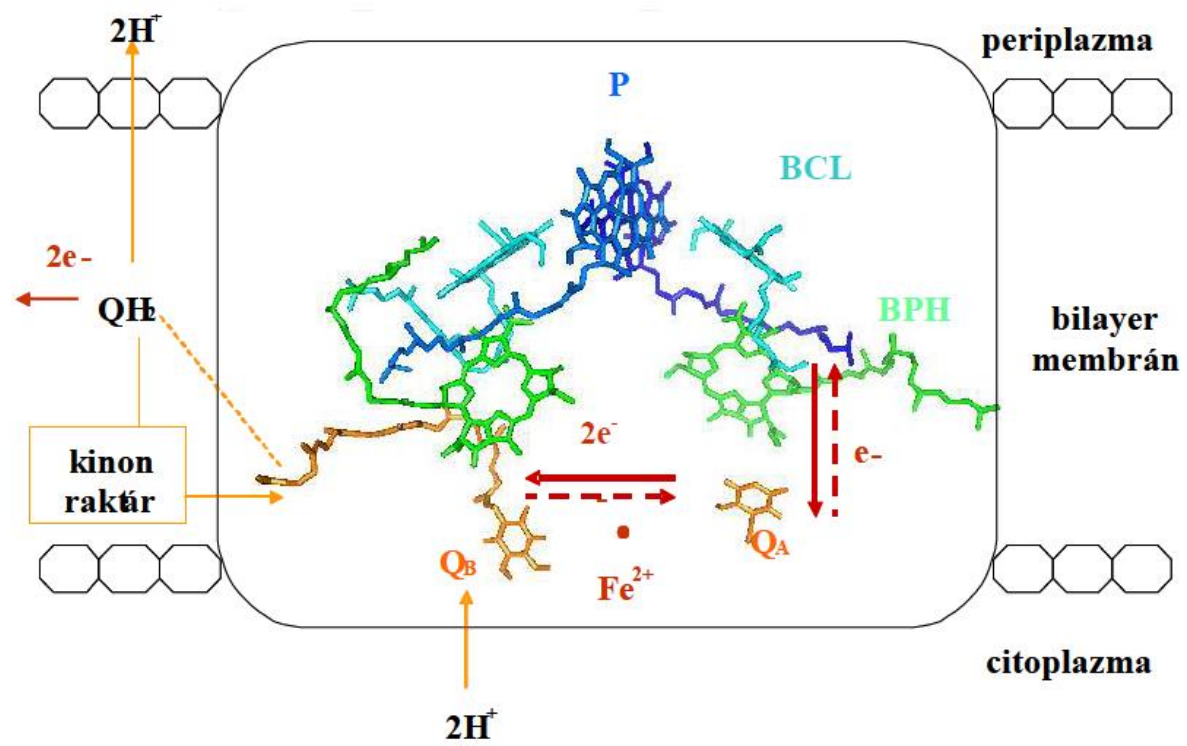

1. ábra A nem-fehérjetermészetű kofaktorok elrendeződésének vázlata a fotoszintetikus membránba ágyazott RC-ban. P: elsődleges elektron-donor, BCL: bakterioklorofill, BPH: bakteriofeofitin, $\mathrm{Q}_{\mathrm{A}}$ : elsődleges kinon, $\mathrm{Q}_{\mathrm{B}}$ : másodlagos kinon, $\mathrm{Fe}^{+}$: nem hem típusú vas. A piros nyilak az elektrontranszport útvonalát, a narancssárgák a kinonok protonációs folyamatokban való résztvételét mutatják (Rinyu, 2007).

Ezt a típust három fehérjealegység alkotja, L, M és $\mathrm{H}$ (light, middle és heavy). Az öt transzmembrán hélixből, főleg apoláris aminosavláncokból álló Lés M-alegység felépítése alig tér el egymástól. A H-alegységet egy 
transzmembrán alfa hélix alkotja, a hidrofil részével a citoplazmatikus oldal felől kapcsolódik az LM-egységhez.

A komplex intracitoplazmatikus membránrendszerbe ágyazva helyezkedik el és különféle fehérjealegységekböl, illetve redox kofaktorokból épül fel.

A redox komponensek két szimmetrikus ágat képeznek, melyekből csak az egyik aktív. Az elsődleges donormolekulát (P) két bakterioklorofill alkotja dimerikus szerveződéssel. Az elektron a P-ről az egyik bakteriofeofitinre jut 3 ps alatt. A bakteriofeofitinröl az elsődleges kinonra mintegy 150 ps alatt, majd az Malegységhez kötődő $\mathrm{Q}_{\mathrm{A}}$ ubikinonról a $\mathrm{Q}_{\mathrm{B}}$ ubikinonra kb. 200-400 $\mu$ s alatt kerül át a gerjesztett elektron (2. ábra). A ciklikus eletrontranszport befejező lépése az elektron visszakerülése P-re, amelyet egy vízoldékony elektrontranszfer molekula, a citokróm $c_{2}$ közvetít a citokróm bc komplexről, így töltve be az elektronmediátor szerepét a két komplex között. A QA elsődleges kinon egy, míg a Q в másodlagos kinon két elektronnal redukálható ki teljesen. A másodlagos kinonból egy elektron felvétele után szemikinon keletkezik, majd a második elektron felvétele után két protont is megköt a vizes fázisból, és dihidro-kinon (kinol) jön létre. A kinol ezt követően leválik a kinonkötőhelyröl, és az elektronokat a citokróm bc komplexhez (egy másik, a fotoszintetikus elektrontranszportban résztvevő fehérjéhez) szállítja. Helyére egy új, oxidált $\mathrm{Q}_{\mathrm{B}}$ kötődik a membrán kinonraktárából (Allen és mtsai., 1998; Paddock és mtsai., 2003; Wraight, 2004; Nagy és mtsai., 2010).

\subsubsection{Egyszeri töltésszétválasztás}

Fénygerjesztést követően töltésszétválasztás indul meg a RC-ban. Az elnyelt foton hatására a $\mathrm{P}$ gerjesztett állapotba jut $\left(\mathrm{PQ}_{\mathrm{A}} \mathrm{Q}_{\mathrm{B}} \Rightarrow \mathrm{P}^{*} \mathrm{Q}_{\mathrm{A}} \mathrm{Q}_{\mathrm{B}}\right)$, majd oxidálódik, és az elektronja az alacsonyabb energiájú $\mathrm{Q}_{\mathrm{A}^{-}}$ra $\left(\mathrm{P}^{*} \mathrm{Q}_{\mathrm{A}} \mathrm{Q}_{\mathrm{B}} \Rightarrow \mathrm{P}^{+} \mathrm{Q}_{\mathrm{A}}{ }^{-} \mathrm{Q}_{\mathrm{B}}\right)$, végül a másodlagos kinonra, $\mathrm{Q}_{\mathrm{B}}-\mathrm{re} \quad\left(\mathrm{P}^{+} \mathrm{Q}_{\mathrm{A}}{ }^{-} \mathrm{Q}_{\mathrm{B}} \Rightarrow \mathrm{P}^{+} \mathrm{Q}_{\mathrm{A}} \mathrm{Q}_{\mathrm{B}}{ }^{-}\right)$kerül. Egyszeri töltésszétválasztásról akkor beszélünk, amikor nem történik újabb gerjesztés, és az elektron $\mathrm{Q}_{\mathbf{B}}{ }^{-}$-ról visszatér a $\mathrm{P}^{+}$-ra a másodlagos donor távollétében. Izolált $\mathrm{RC}$ okban - az izolálási körülmények miatt - egyéb donor rendszerint nincs jelen, így a fénygerjesztést követően a keletkezett töltéspár rekombinációja figyelhető meg (2. ábra). 


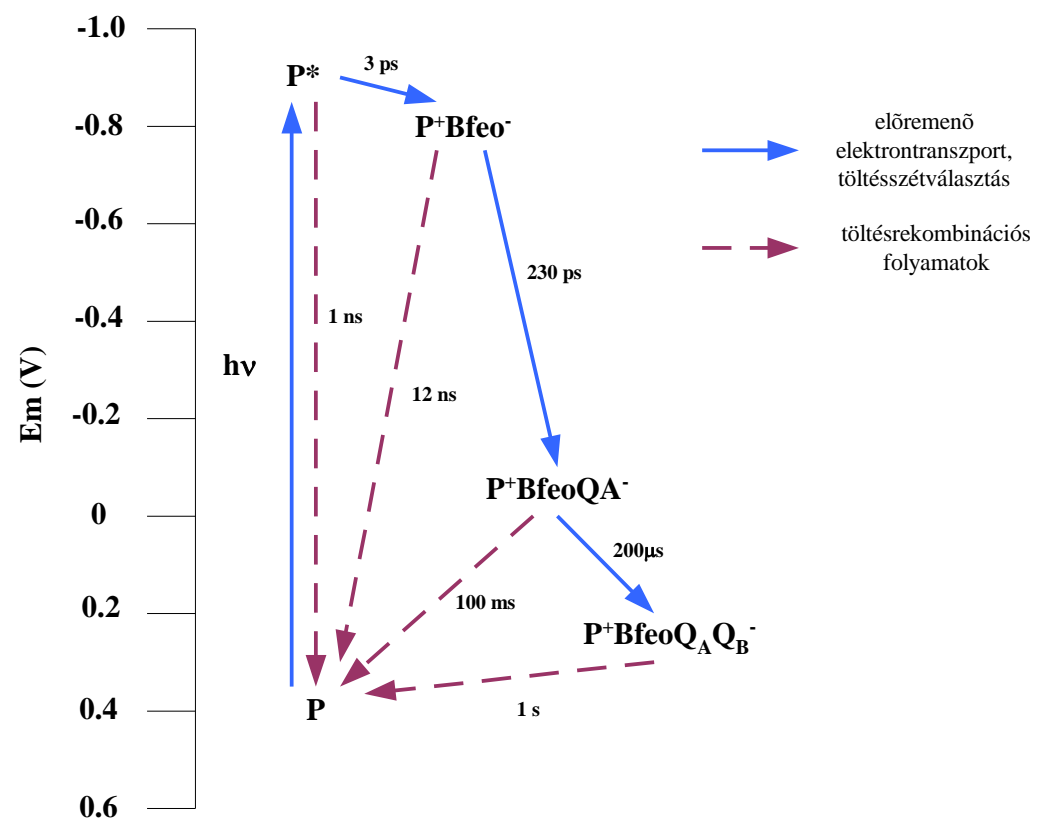

2. ábra A töltésszétválasztás vázlata $R b$. sphaeroides RC-ában fénygerjesztést követően. A folytonos kék nyilak az elöremenő elektrontranszportot, míg a szaggatott bordó nyilak a visszairányú töltésrekombinációs folyamatokat mutatják. A függőleges tengelyen a normál hidrogénelektródhoz viszonyított középponti potenciál található. A számadatok az egyes reakciók természetes élettartamát jelentik.

Rhodobacter $(R b$.$) sphaeroides \mathrm{R}-26$ törzs esetén a $\mathrm{P}^{+} \mathrm{Q}_{\mathrm{A}}{ }^{-}$töltéspár élettartama kb. $\tau \approx 100 \mathrm{~ms}$, szemben a $\mathrm{P}^{+}\left(\mathrm{Q}_{\mathrm{A}} \mathrm{Q}_{\mathrm{B}}\right)^{-} \tau \approx 1 \mathrm{~s}-$ os élettartamával. $\mathrm{A}_{\mathrm{B}}{ }^{-}$ ról a $\mathrm{P}^{+}$-ra az elektron kb. 95\%-os valószínüséggel a $\mathrm{Q}_{\mathrm{A}}-\mathrm{n}$ keresztül kerül vissza (indirekt út), a fennmaradó 5\%-ban közvetlen töltésrekombináció történik a fehérjemátrixon keresztül. A folyamatok irányát és az időállandókat a 2. ábra szemlélteti (Nelson és mtsai., 2009).

\subsubsection{Többszöri töltésszétválasztás}

Nem természetes körülmények között másodlagos donor nélkül töltésrekombinációval ér véget a fotociklus. Fiziológiás körülmények között vagy hozzáadott külső elektrondonorral erre kicsi az esély, mivel a $\left(\mathrm{P}^{+} \mathrm{Q}_{\mathrm{A}}{ }^{-}\right)$töltéspárt még a rekombináció előtt redukálja egy másodlagos donor molekula, pl. citokróm $\mathrm{c}^{2+}$, vagy mesterséges elektrondonor. Ezt követően ismételt fénygerjesztés hatására újabb töltésszétválasztás történhet (Kleinfeld és mtsai., 2010), hiszen az 
oxidált $\mathrm{P}$ azonnal visszaredukálódhat, és újból gerjeszthető állapotba kerül. A második gerjesztő foton heterogén állapotú $\mathrm{RC}$-ot ér $\left(\mathrm{Q}_{\mathrm{A}}{ }^{-} \mathrm{Q}_{B}\right.$ és $\mathrm{Q}_{\mathrm{A}} \mathrm{Q}_{\mathrm{B}}{ }^{-}$állapotok), és csak az oxidált $\mathrm{Q}_{\mathrm{A}}$-t tartalmazó RC-ban történik még egy töltésszétválasztás. A $\mathrm{Q}_{\mathrm{A}}$ egy, a $\mathrm{Q}_{\mathrm{B}}$ két elektron fogadására képes. A fényfelvillanásokat követően a vizes fázisból két proton kötődik a $\mathrm{Q}_{\mathrm{B}}$-hez, és az dihidrokinol formájában (kinol, $\mathrm{QH}_{2}$ ) leválik a RC-ról. Helyére új, oxidált kinon kötődik (3. ábra).

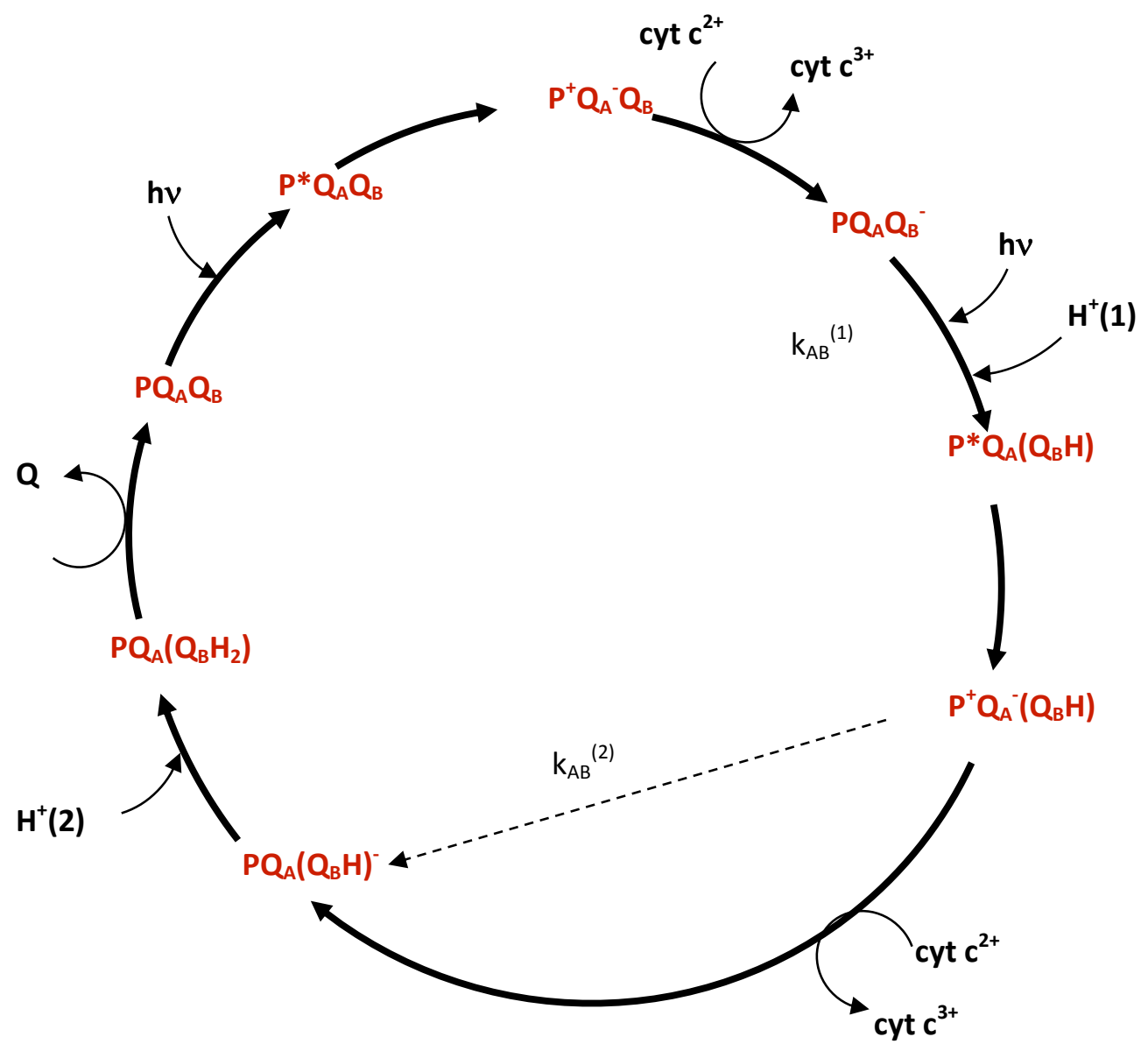

3. ábra A fotoszintetikus reakciócentrumban végbemenő folyamatok sorozatos fényimpulzusokkal történő gerjesztéskor. Az ábrán feltüntettem az elektrontranszfer útját, a protontranszport, a cyt $\mathrm{c}^{2+}$ oxidációjának és a kinoncserének a lehetőségeit. $\mathrm{Q}, \mathrm{Q}_{\mathrm{A}}, \mathrm{Q}_{\mathrm{B}}$ oxidált, $\mathrm{Q}_{\mathrm{A}}^{-}, \mathrm{Q}_{\mathrm{B}}{ }^{-}$redukált, $\left(\mathrm{Q}_{\mathrm{B}} \mathrm{H}\right)^{-},\left(\mathrm{Q}_{\mathrm{B}} \mathrm{H}_{2}\right), \mathrm{QH}_{2}$ protonált kinonformák; cyt $\mathrm{c}^{2+}$ redukált, cyt $\mathrm{c}^{3+}$ oxidált citokrómformák; $\mathrm{P}$ elsődleges donor; $\mathrm{H}^{+}(1)$ valamint $\mathrm{H}^{+}(2)$ első és második proton.

A ciklikus redox lépések sorozata által a RC igen nagy, megközelítőleg 100\%-os hatékonysággal tudja hasznosítani a beérkező fotonok energiáját, amit 
aztán kémiai, transzmembrán potenciállá alakít (Mitchel, 1972), így biztosítva a szabadenergiát a sejt energiaigényes folyamataihoz. A folyamat in vitro körülmények között is müködik, külső elektrondonor használatával. Kiváló tulajdonságainak köszönhetően a RC megfelelő jelölt bio-nanokompozitok előállításához (Lu és mtsai., 2005; 2007; Dorogi és mtsai., 2006; Ohmori és mtsai., 2008, Tan és mtsai., 2012).

\subsection{3. $\mathrm{A}^{1} \mathrm{O}_{2}$ képződés mechanizmusa RC-ban}

A fotoszintetizáló rendszerekben a fény elnyeléséért felelős festékmolekulák fényabszorpciót követően gerjesztett állapotba kerülnek. Első szinglet gerjesztett állapotuk átalakulhat hosszabb életidejü triplet állapotba a gerjesztett elektron spinjének megfordulásával. A triplet állapotú festékmolekulák semlegesítése történhet fizikai és kémiai úton egyaránt. Az első esetben energiatranszferrel, míg a második esetben egy úgynevezett kioltó molekula oxidációja révén valósul meg a molekula alapállapotba kerülése.

A Rhodobacter sphaeroides reakciócentrumában, ha az antennák vagy a primer donor energiaelnyelése meghaladja a fotoszintézisre használható energia mennyiségét, vagy gátolt az elektronátadás az akceptorok irányában, hosszabb lesz a ${ }^{1} \mathrm{Bchl} *$ életideje, mivel a tárolt energia nem kerül azonnali felhasználásra a fotokémiai reakcióban. Így megnő annak a valószínűsége, hogy a ${ }^{1} \mathrm{Bchl} *$ alacsonyabb energiájú ${ }^{3} \mathrm{Bchl} *$ állapotba kerül, amely kedvez a ${ }^{1} \mathrm{O}_{2}$ képződésnek (Telfer és mtsai., 1994; Tandori és mtsai., 2001; Arellano és mtsai., 2007). Az élőlény típusától (fajtól) függően a RC-okban valamilyen karotinoidmolekula a felvett energiát energiatranszfert követően vibrációs mozgásokkal, hő formájában sugározza ki. A folyamat ismételhető, a molekula nem sérül a deaktiválás során. A kioltáshoz elengedhetetlen a karotinoid és a klorofill molekula kis, 11 Å-ös távolsága, hiszen az energiaátadás a távolsággal exponenciálisan csökken (de Winted és Boxer, 1999). Ezzel a mechanizmussal csökkentik a karotinoidok a fotooxidáció valószínüségét, amely nélkül a $\mathrm{RC}$ irreverzibilesen károsodna a folyamat során.

A primer donor bakterioklorofilljai mellett a bakteriofeofitinek is részt vehetnek a ${ }^{1} \mathrm{O}_{2}$ képzésében (Uchoa és mtsai., 2008), ráadásul a $\mathrm{BChl-lel} \mathrm{szemben}$ 
van der Waals távolságon kívül helyezkedik el a karotinoidoktól, így nem érvényesül a karotinoidok kioltó hatása (4. ábra). A fehérjében keletkező igen reaktív szinglet oxigén jelentősen lerövidítheti a RC élettartamát, az általunk készített komplexben is az immobilizálást követően.

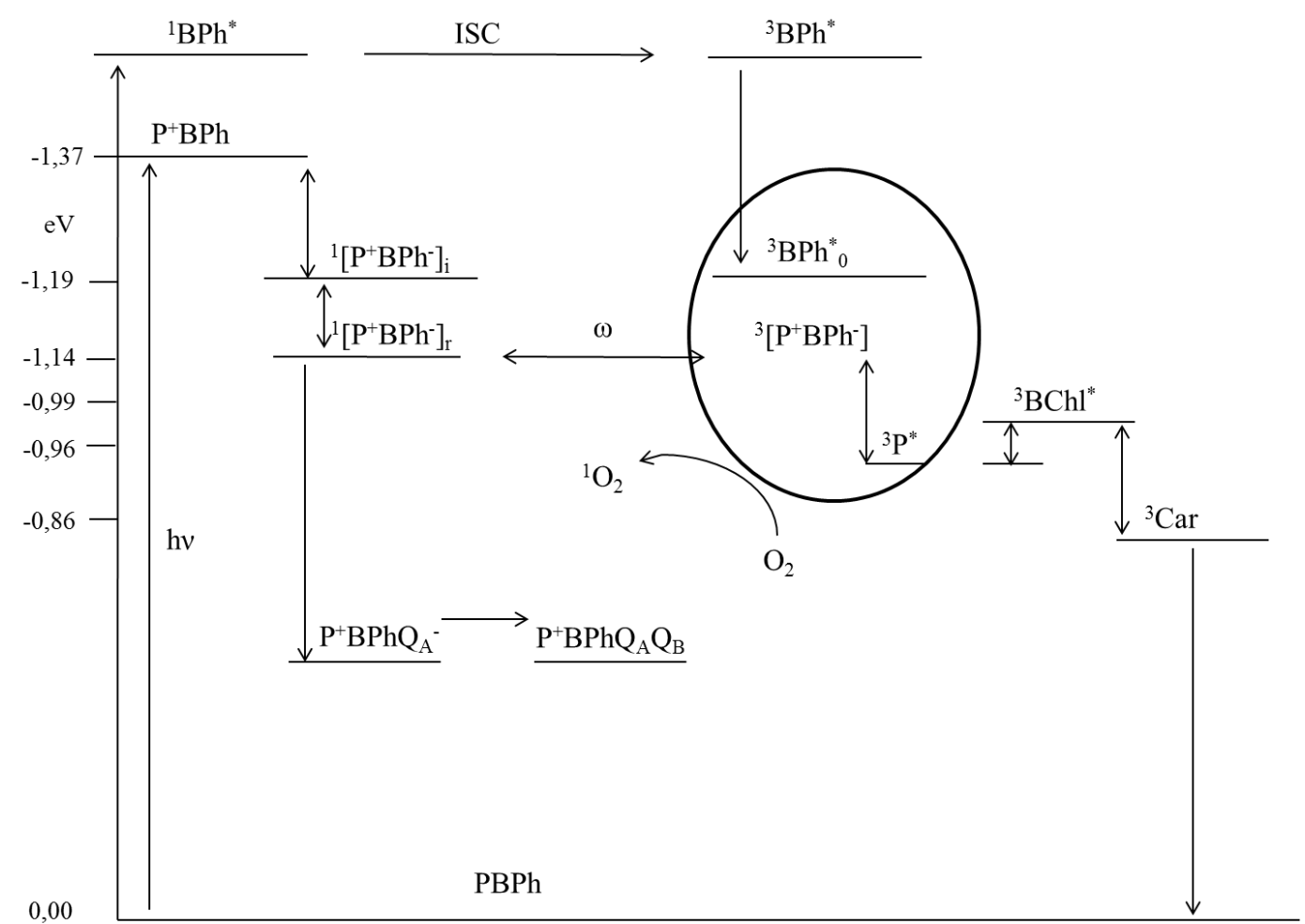

4. ábra $\mathrm{A}^{1} \mathrm{O}_{2}$ keletkezésének lehetséges reakcióútjai vad típusú Rhodobacter sphaeroides reakciócentrumban. P - primer donor, BChl - bakterioklorofill, BPh - bakteriofeofitin, Q kinon és Car - karotinoid. ${ }^{1}\left[\mathrm{P}^{+} \mathrm{BPh}\right]_{\mathrm{i}, \mathrm{r}}$ a kezdeti és a relaxált állapota a primer ion-gyök párnak. $\omega-$ a szinglet és triplet állapotok egymásba alakulásának folyamata, ISC szinglet-triplet átmenet (Uchoa és mtsai., 2008, Arellano és mtsai. 2007).

\subsection{Szilícium alapú hordozók biokompozitokban}

A kompozit anyagok előállítása során az egyik legmeghatározóbb lépés a hordozóanyag kiválasztása. Fontos a megfelelő mátrix anyag megtalálása, hiszen ez alapvetően meghatározza a kompozit tulajdonságait, valamint optimális körülményeket kell biztosítania a rögzített biológiai anyagnak. Biokompozitok előállítása során - érzékeny anyagokról lévén szó - sok kritériumnak kell megfelelni. Elsődleges feltétel a biokompatibilitás, de emellett fontos az is, hogy a 
rendszerünk stabil, homogén legyen, optimális fizikai és kémiai paraméterekkel. Különös figyelem fordult a porózus anyagok felé, részben azért, mert a nagy fajlagos felület miatt sok anyagot tudnak megkötni, másrészt a porozitás nem csak egyszerüen felületnagyobbítást eredményez, hanem olykor különleges fotonikai struktúrát is kölcsönöz a rendszernek. Porózus hordozó esetén megfelelőnek kell lennie a pórusméretnek és a porozitásnak, esetenként a pórusok elrendeződésének és struktúrájának is. Egyes esetekben az anyag zsugorodása is gondot okozhat. Tehát számos tényezőt figyelembe kell venni, ha biológiai anyagokkal kívánunk dolgozni.

A szilícium alapú szervetlen hordozók több szempontból is megfelelő jelöltek biológiailag aktív anyagok megkötésére, hiszen nem toxikusak, biológiailag inertek, viszonylag olcsóak, nagy mennyiségben állnak rendelkezésre, és könnyen kezelhető anyagok. Karakterisztikus tulajdonságaiknak köszönhetően számos különböző módon használhatjuk fel, pl. elektronikai-, orvosi-, bioszenzor alkalmazásokban (Rooke és mtsai., 2008, Aroutiounian és mtsai., 2008). Különböző fizikai-kémiai eljárásokkal magát a szilíciumlapot is kezelhetjük, hogy megfelelő tulajdonságokkal bíró anyagot kapjunk, illetve egyéb anyagokkal társítva is felhasználhatjuk a szilíciumot.

Kétféle szilícium alapú hordozóval, és különböző kötési technikákkal dolgoztam. Az első esetben a lúdfü egész növényi sejteket szol-gél módszerrel immobilizáltam szilika gélben. A kompozit megfelelő pórusmérettel rendelkezett, és tartalmazta a növényi sejteknek fontos tápanyagokat, így biztosítva számukra a megfelelő körülményeket aktivitásuk megörzéséhez. A második esetben porózus szilíciumot használtam, ami egy szilárd, igen nagy porozitással rendelkező, szilícium alapú hordozó. Az általam használt mikrokavitással rendelkező szilícium lapok többek között pórusméretükből fakadóan kiváló jelöltnek bizonyultak fotoszintetikus reakciócentrumok immobilizálásához. 


\subsubsection{A szol-gél mátrix}

\subsubsection{A szol-gél eljárás jellemzése}

A szol-gél eljárás során először szerves vagy szervetlen anyagból kolloidikus ("szol") szuszpenziót hozunk létre, amely azután átalakul egy igen viszkózus gél struktúrába, és ezt követően akár szilárd anyaggá is. Ezzel a módszerrel eloállíthatóak nagy porozitású és nanokristályos anyagok. Az általam élő sejtek rögzítéséhez használt szilikagél hordozó tulajdonképpen már önmagában is kompozit anyagnak tekinthetö, tartalmazza a sejtek életmüködéseihez szükséges anyagokat is. Optikai tulajdonságai nagyon előnyösek. Mivel átlátszó anyag, biztosítja a sejtek fényen való növekedését, és a fotoszintetikus müködés vizsgálhatóságát is. A gél létrehozásához használatos prekurzor anyagok megfelelő kémiai módosításával jól szabályozható többek között a pórusméret és a porozitás, illetve a pórusok falának kémiai tulajdonsága. Funkcionált prekurzorok használatával lehetséges szerves és biológiai anyagok kötése a szilikát struktúrához (Wright és Sommerdijk, 2000).

\subsubsection{Biológiai anyagok rögzítése szol-gél módszerrel}

Bár a szol-gél módszer nem kifejezetten csak biológiai anyagok megkötésére irányul, több olyan tulajdonsággal bír, melyek miatt gyakran alkalmazzák az ilyen jellegü kísérletek során. A preparáláshoz szükséges hőmérséklet alacsony, általában szobahőmérséklethez közeli, így magának a hordozónak, és az abban rögzített anyagnak a termális degradációja is minimális. Többnyire nem igényel extrém kémiai körülményeket (pl. szélsőséges pH-t, ozmotikus nyomást). A folyamat első és második lépését, tehát a hidrolízist és a kondenzációt valamilyen sav vagy bázis katalizálja, azonban az extrém $\mathrm{pH}$ könnyen elkerülhető, ha két lépésben történik a katalízis, és a savas katalízist egy gyors pufferelés követi.

Biokompozitok létrehozására elsőként Braun és munkatársai használtak szol-gél módszert. 1990-ben megjelent cikkükben enzimet kötöttek tetraetilortoszilikát (TEOS) alapú szol-gél mátrixhoz (Braun és mtsai., 1990). Az 
eljárás hasonló módon müködött egyéb biológiai rendszerekkel is, mint például tilakoidokkal, kloroplasztiszokkal és cianobaktériumokkal (Nassif és mtsai., 2002; Rooke és mtsai., 2008; Meunier és mtsai., 2009). Carturan és csoportja volt az első, akiknek sikerült egész növényi sejteket rögzíteni szol-gél módszerrel (Campostrini és mtsai., 1996; Carturan és mtsai., 1998). Ezekben a kompozitokban a sejtek megőrizték az enzimatikus aktivitásukat, ellenben az életképességükről nincsen pontos adat. Ezek a kísérletek megteremtették a bioszenzorok és bioreaktorok tervezésének lehetőségét.

\subsubsection{A porózus szilícium}

\subsubsection{A porózus szilícium szerkezete és tulajdonságai}

Manapság a szilícium az egyik legelterjedtebb anyag a félvezető technikában, hiszen nem csak könnyen kezelhető, de nagy mennyiségben áll rendelkezésünkre és olcsó (Aroutiounian és mtsai., 2008). Intenzív kutatások folynak a szilícium felhasználási területeinek kiterjesztésére, a különböző elektronikai alkalmazásoktól egészen az orvostudományig.

A szilíciumlap felszínében nedves elektrokémiai eljárással pontosan tervezhető réteges, porózus szerkezet alakítható ki. Az így létrejött struktúrával rendelkező anyagot nevezzük porózus szilíciumnak (PSi). A pórusok mérete és a rétegek száma, elhelyezkedése is pontosan szabályozható. Az eljárást követően a porózus szilícium (PSi) egy olyan réteges, fotonikai struktúrával rendelkezik, amelynek reflexiós spektruma jellemző az adott réteges struktúrára, és rendelkezik egy, a Bragg feltételeknek megfelelő reflexiós módussal. A rétegszerkezet tervezett kialakításával (rétegek száma, elrendezése, pórusméret) a csúcs bárhol elhelyezkedhet a látható és az infravörös tartományon belül.

A speciális elektrokémiai eljárásnak köszönhetően a porózus szilícium réteges struktúrája tervezhető úgy, hogy abban két, negyed hullámhossz vastagságú, különböző törésmutatójú réteg váltakozik, középen fél hullámhossz vastagságú “aktív réteggel”(5. ábra). 


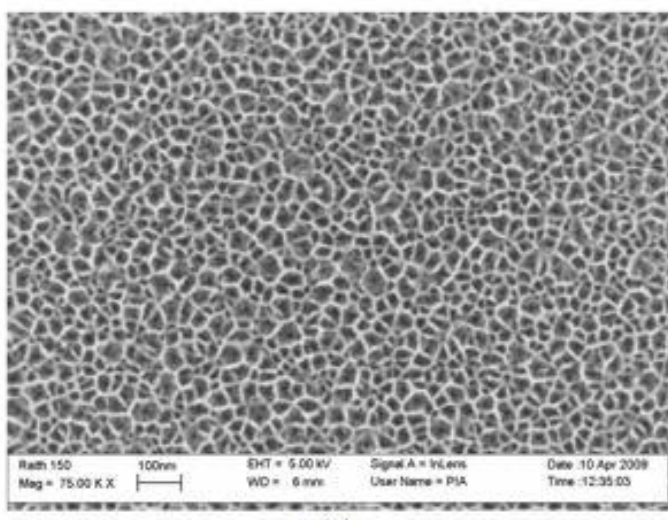

(a)

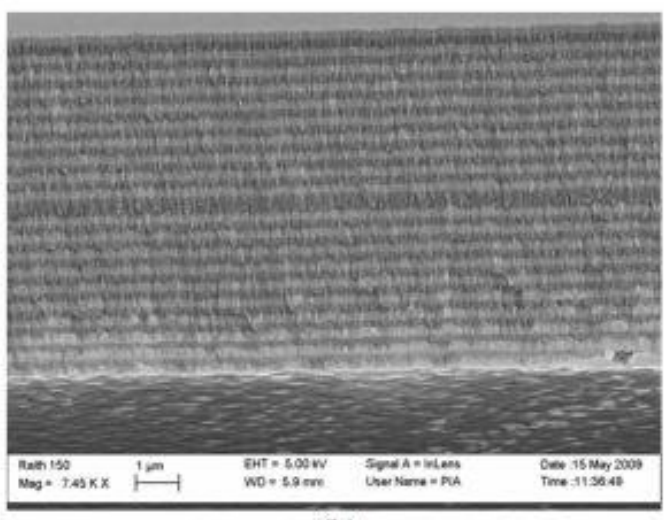

(b)

5. ábra PSi lapról készült SEM felvétel (a) felülnézetből; (b) oldalnézetből (Tkachenko és mtsai., 2009)

A periodicitás egy olyan fotonikus szerkezetet biztosít, amelyre jellemzö, hogy bizonyos hullámhossztartományokban a beeső fény nem terjed tovább, teljes mértékben visszaverődik. Ez az egyedi szerkezet elöre tervezhető, és a kívánt felhasználási célok szerint megváltoztatható. Sok alkalmazásnál fontos lehet a reflexiós csúcs helye, amely érzékenyen reagál a felszíni tulajdonságokra és a rendszer törésmutatójára. Ezek a jellemzők többek között akkor is megváltozhatnak, ha molekulák, biomolekulák kerülnek a porózus szerkezetbe. A változás mértéke legtöbbször egyenes arányban áll a pórusokba került anyagmennyiséggel. Ennek a specifikus tulajdonságnak köszönhető, hogy a pórusokban rögzített anyagok mennyisége könnyedén nyomon követhető a reflexiós csúcs eltolódásával. A rendszer felszíni tulajdonságai és törésmutatója megváltozik ebben az esetben, ezáltal lehetségessé válik a megkötött molekulák detektálása akár kvantitatív módon is. A reflexiós módus hullámhosszának eltolódása azt jelzi, hogy az immobilizált anyag beépült a PSi fotonikai struktúrájába.

A PSi tartalmú kompozitok használati lehetőségeiről egyre szélesebb körben gondolkoznak, elsősorban fotonikus alkalmazásban, szenzorként vagy gyógyszer hordozóként (Oda és mtsai., 2006; Agarwal és mtsai., 2003; Estevez és mtsai., 2009; Martin és mtsai., 2009; Thomson és mtsai., 2010; Estephan és mtsai., 2011; Palestino és mtsai., 2008; Xiao és mtsai., 2011). Különleges paramétereinek köszönhetően egyedülálló lehetőségeket biztosít az integrált optoelektronikában és bioszenzorok elöállításához egyaránt (Thomson és mtsai., 2010; Estephan és mtsai., 2011; Wu, 2011; Kilian és mtsai., 2007). 


\subsubsection{A porózus szilícium és a biológiai anyagok}

A bio-nanokompozitok egyik ígéretes hordozó szubsztrátja a szilícium. Napjainkban a legszélesebb körben alkalmazott anyag a félvezető technológiákban, valamint, mivel biokompatibilis, előszeretettel használják biológiai anyagok hordozójaként (Oda és mtsai., 2006; 2010; Meuner és mtsai., 2009; Fukushima és mtsai., 1996; Noji és mtsai., 2011). Alkalmazásával egyrészt, megfelelő környezet biztosítható az in vivo környezetből kiszakított, immobilizált anyagok hatékony müködéséhez. Másrészt, speciális elektromos vezetési tulajdonságai miatt alkalmas ,interface” lehet, elsősorban redox aktív fehérjék müködéséhez, akár azok optoelektronikai alkalmazásaiban is.

In vitro alkalmazásban már most is léteznek szilícium alapú bioszenzorok. Két különböző típusuk ismert, egyrészt amelyek egyes komponensek mennyiségét detektálják egy összetett biológiai rendszerben, általában valamilyen rögzített receptor vagy enzim segítségével, másrészt, amelyek élő sejtek életképességét detektálják (Chin és mtsai., 2001; Anglin és mtsai., 2004; Stefano és mtsai., 2006). Bár az elmúlt években egyre szélesebb körben elterjedt a szilícium alapú eszközök in vitro alkalmazása, eddig az in vivo alkalmazások nem kerültek előtérbe.

A porózus szilícium kivételes lehetőséget nyújt a biológiai anyagok rögzítési technológiájában. Népszerüsége olyan kiváló tulajdonságaiból adódik, mint (a) szabályozható pórusméret (b) nagy felület (c) réteges fotonikus szerkezet (d) egyszerü és olcsó előállítás (e) biológiai lebonthatóság.

Különféle formában alkalmazzák a PSi-t biokompozitokban, akár mint hordozó anyag, ami nem befolyásolja közvetlenül a biológiai anyag müködését, csak megfelelő környezetet biztosít annak, illetve akár, mint aktív komponens, amikor félvezető tulajdonságai révén részt vesz pl. töltésszétválasztó és stabilizáló folyamatokban.

A porózus szilícium lehetséges alkalmazásait három fő csoportba sorolhatjuk: $a$, in vitro bioszenzorok előállítása $b$, különféle beültethető orvosi eszközök tökéletesítése $c$, biológiai interfész hálózatok létrehozása (Mayne és mtsai., 2000). A jövő biokompozitjai egyik alapkövének is mondják, mivel jelentősen megnövelik a rendelkezésre álló felületet az eddig használt szilícium 
szubsztrátokhoz képest. A nagyobb felületnek köszönhetően a rendszer érzékenysége is megnő.

In vivo alkalmazások kutatásai során, ahol a hordozó közvetlenül érintkezik az élő sejtekkel, már ma is igen gyakran PSi-ot használnak. Számos biomolekula, pl. a humán szérum albumin (HSA), a glükózoxidáz (GOX) és a fibrinogén adszorpciója is jól mérhető PSi-on (Canham és mtsai., 1999). A nanokristályos PSi filmek nem csak bioszenzorként, de kromatográfként is használhatóak. A pár nanométer átmérőjü pórusokkal rendelkező filmek alkalmasak a biomolekulák méret szerinti elválasztására, makromolekulák meghatározására (Collins és mtsai., 2002). Ezen az úton haladva, a fehérjék elválasztásának és meghatározásának céljából a PSi filmek preparálása során a pórusrendszer jobb szabályozhatóságára, tervezhetőségére törekedtek. A proteinek szabályozott megkötése igen hasznosnak bizonyult a különféle gyógyszer adagolási technikákban (Guinan és mtsai., 2013).

A szilícium nanostruktúráknak fontos szerep juthat többek között az orvosi diagnosztikában vagy bioszenzorok létrehozásában (Cunin és mtsai., 2002). A sajátos fotonikai struktúra jó lehetőséget (és egyben kihívást is) kínál a fotoaktív pigment-protein komplexek és a PSi társítására új biofotonikus alkalmazások létrehozására.

\subsection{Szén nanocsövek}

\subsubsection{A szén nanocsövek szerkezete és tulajdonságai}

Miután Richard Smalley, Robert Curl és Sir Harold Kroto felfedezte a fullerént $\left(\mathrm{C}_{60}\right.$; Kroto és mtsai., 1985), mindössze hat év telt el és Japánban Sumio Iijima és csoportja egy újabb szén nanoszerkezetre, egy addig még ismeretlen allotróp szénmódosulatra bukkant, ez pedig a többfalú szén nanocső volt (multi walled carbon nanotube - MWCNT; Iijima, 1991). Két évvel később, 1993-ban szintén Iijima és csoportja felfedezte az egyfalú szén nanocsöveket is (single walled carbon nanotube - SWCNT; Iijima és Ichihashi, 1993), lehetőségek tárházát nyitva meg a nanorendszerek és újgenerációs nanokompozit anyagok kutatása elött. A szén nanocsövek olyan előnyös tulajdonságokkal bírnak, mint a kiváló vezetőképesség vagy a rendkívüli mechanikai tulajdonságok, így számos 
területen fel lehet használni öket, az orvostudománytól az ürkutatásig (Iijima Sumio, Louis Brus, Kavli díj, 2008).

Az egyfalú szén nanocsövek (SWCNT) leírhatóak úgy, mint egyetlen feltekert grafitsík, melynek két végét látszólag kettévágott fullerénekkel zárják le. Szerkezetük, a grafitsíkhoz hasonlóan, hatszöges grafén lapokból áll. A grafitsík feltekeredési módjától függően a királis szög különböző értékeket vehet fel $\left(\Theta=30^{\circ}, \quad \Theta=0^{\circ}\right.$ és $\left.0^{\circ}<\Theta<30^{\circ}\right)$, mely szerint három különböző típusát különböztetjük meg a nanocsöveknek. Ezek sorrendben a királis, illetve a két nem királis, a karosszék és a cikk-cakk elrendezésű szén nanocsövek.

A többfalú szén nanocsöveket (MWCNT) úgy képzelhetjük el, mint több, koaxiálisan rendezett, különböző átmérőjü, koncentrikusan egymásban elhelyezkedő egyfalú szén nanocsövet (Collins és mtsai., 2001). Az egymás köré tekeredő nanocsöveket gyenge van der Waals kölcsönhatás kapcsolja össze. Átlagosan $10 \mathrm{~nm}$ az átméröjük, de ez az érték az egymás köré tekeredő grafit rétegek számától függően változhat (akár $80-100 \mathrm{~nm}$ is lehet). Hosszuk pár mikrométer, sőt milliméter is lehet, így általánosságban elmondható róluk, hogy hossz/átmérő arányuk nagyobb, mint 1000.

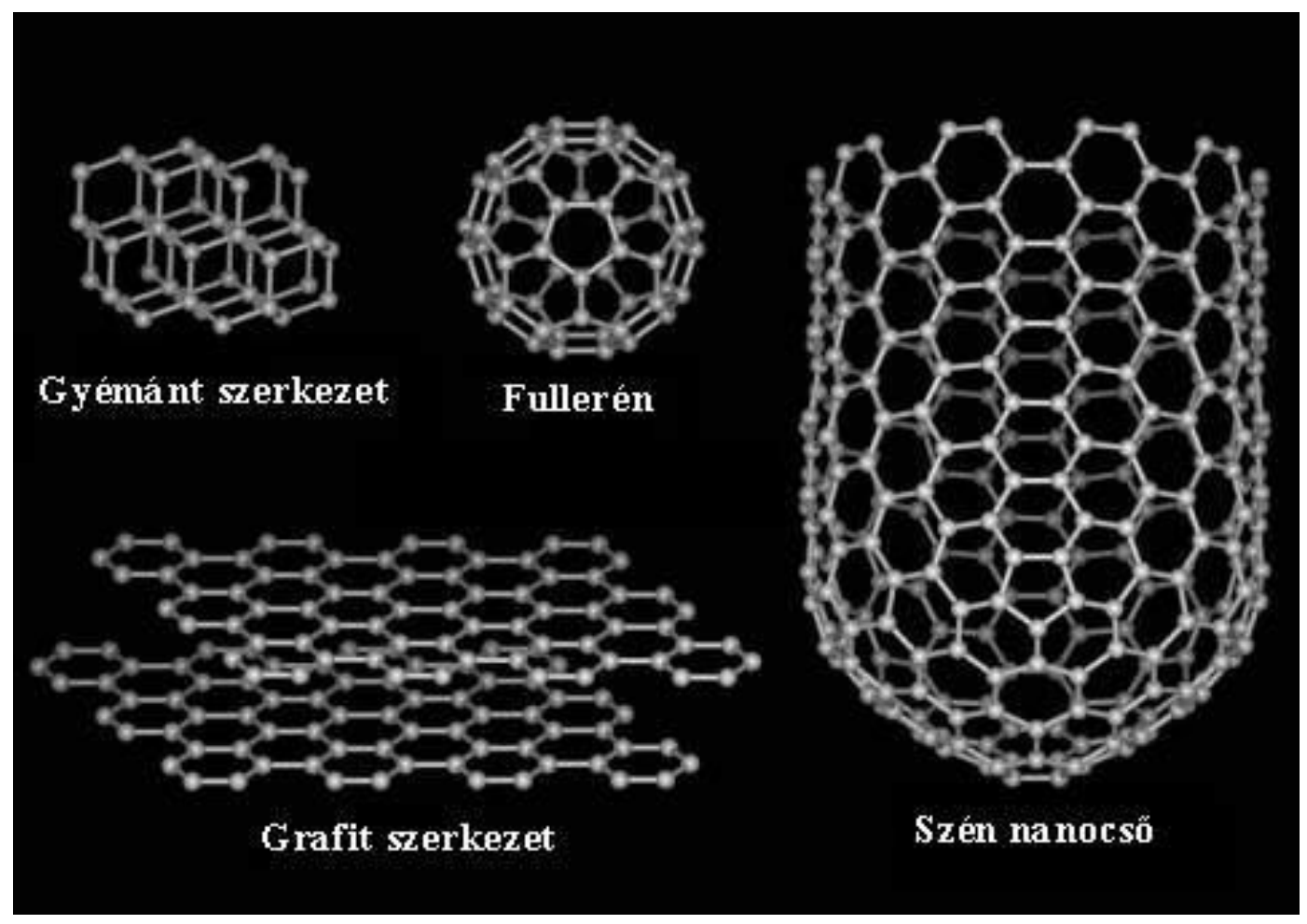

6. ábra A szén allotróp módosulatai: gyémánt, grafit, fullerén és szén nanocső 
A szén nanocsövek felfedezése óta széleskörü kutatások folynak azzal kapcsolatban is, hogy hogyan lehet őket kompozit anyagokban hasznosítani. Néhány esetben szükséges lehet a nanocsövek felületmódosítása, amely történhet fizikai és kémiai módon. Megváltoztathatóak a nanocsövek oldhatósági tulajdonságai, vagy kémiai felületmódosítással különböző vegyületekkel funkciós csoportokat hozunk létre a nanocsövek felületén, amelyek a szénatomokkal erős kémiai kötést tudnak kialakítani.

\subsubsection{A szén nanocsövek és a biológiai anyagok közötti kölcsönhatás}

A szén nanocsövek kiváló kémiai és fizikai paramétereiknek köszönhetően igen népszerü hordozók a bio-nanokompozitok előállítása során (Bianco és mtsai. 2005). Többféle biológiai anyagot immobilizáltak sikeresen szén nanocsövek felszínén, mint pl. DNS-t (Singh és mtsai., 2005) hidrogenázt (Ciaccafava és mtsai., 2012), glükóz oxidázt (GOX, Guiseppi-Elie és mtsai, 2002), hidrogén peroxidázt (Magyar és mtsai., 2013). Mivel jellemző rájuk a nagymértékü rendezettség, és a redox-enzimekkel való funkcionális kapcsolat lehetősége, a szén nanocsövek immobilizációs mátrixként vagy mediátorként is használhatók harmadik generációs amperometriás bioszenzorok kifejlesztésénél (Tsai és mtsai., 2006; Gooding és mtsai., 2003; Lebedev és mtsai., 2008; Lu és mtsai., 2005; 2007). Biológiai alkalmazásukkal kapcsolatban a mai napig vita tárgyát képezi biokompatibilitásuk és citotoxicitásuk. Ebben az irányban számos vizsgálatot elvégeztek már a szén nanocsöveken, föként egész sejtekre kifejtett hatásukat vizsgálták (Magrez és mtsai., 2006; 2006; Hurt és mtsai., 2006; Liu és mtsai., 2009; Kim és mtsai., 2011). Kisebb biológiai molekulák, fehérjék esetében a szén nanocső mindenféleképpen megfelelő hordozónak bizonyult.

Fotoszintetikus fehérjékkel képzett nanocső kompozitok esetén a nanocső, jó elektromos vezetési tulajdonságaiból adódóan, ideális hordozónak bizonyult (Lebedev és mtsai., 2008). Kutatócsoportunk korábbi eredményei is bizonyították, hogy a szén nanocsövek fotoszintetikus reakciócentrummal alkotott komplexei képesek a töltésátviteli állapotok stabilizálására is (Dorogi és mtsai., 2006, Szabó és mtsai., 2012). 


\section{Célkitüzések}

Prof. Bao Lian Su (FUNDP, Namur, Belgium) laboratóriumában lehetőségem nyílt megismerkedni a kutatócsoportja munkájával. Betekintést nyertem abba, hogyan történik az egész növényi sejtek rögzítése hordozó felületekhez, mely során lehetőség nyílik új zöld technológiák kidolgozására.

Tekintettel arra, hogy a fotoszintetikus reakciócentrumban történnek a fényenergia kémiai energiává alakításának legelső lépései, valamint ennek a fehérjének a bio-nanotechnológiában való alkalmazása napjainkban nagyon sok laboratórium érdeklődésének a középpontjában áll, egy olyan kutatócsoport munkájába szerettem volna bekapcsolódni, ahol ilyen irányú kutatásokat folytathatok.

Mindezeket figyelembe véve, munkám során célul tüztem ki:

1. Arabidopsis thaliana (lúdfü) egész növényi sejtek rögzítését szilícium alapú hibrid gélben szol-gél módszerrel, valamint a kompozit alapvető fotokémiai/-fizikai folyamatainak meghatározását.

2. Bio-nanokompozitok készítését Rhodobacter sphaeroides bíborbaktérium törzsböl izolált és tisztított fotoszintetikus reakciócentrum fehérje (RC) vezető vagy félvezető hordozó anyag felületén történő fizikai és kémiai kötése révén.

2.1. A fotoszintetikus reakciócentrum fehérje kémiai rögzítését aminocsoporttal funkcionalizált szén nanocső (CNT) felületén. A létrehozott kompozitok szerkezeti karakterizálását (AFM, SEM), és fotoaktivitásuknak meghatározását flashfotolízis kísérletekkel.

2.2. A fotoszintetikus reakciócentrum fehérjének mind kémiai, mind fizikai úton való rögzítését porózus szilícium felületéhez, a kompozitok szerkezeti meghatározását (SEM, EDX), a különböző kötések hatékonyságának kimutatását (Fourier Transzformációs Infravörös Spektroszkópia), és a RC fotokémiai/-fizikai aktivitásának meghatározását a különböző kötési eljárásokat követően (flashfotolízis kísérletek). 


\section{Anyagok és módszerek}

\subsection{Mintaelőkészítés, preparatív eljárások}

\subsubsection{A növényi sejtkultúra jellemzése}

Szuszpenzióban nevelt, Arabidopsis thaliana levelekből származó sejtkultúrát használtam. L-MM1, Landberg erecta típusú sejteket neveltem Murashige és Skoog tápoldatban (MS médium, pH 5.7). Kiegészítő tápanyagként szacharózt (30 g/l), kinetint és $0,5 \mu \mathrm{g} / \mathrm{ml}$ NAA-t (a-naftalén ecetsav) használtam. A sejtek 18/8 órás fény/sötét fotoperiódusban, $25{ }^{\circ} \mathrm{C}$-on, $115 \mathrm{rpm}$-es kevertetés mellett nőttek. A tápoldatot nyolc héten át minden 7. napon, tehát összesen nyolcszor frissítettem (Murashige és Skoog, 1962; Perullini és mtsai., 2007; Meunier és mtsai. 2010).

\subsubsection{A Rhodobacter sphaeroides baktériumtörzs tenyésztése}

Vizsgálataimhoz a Rb. sphaeroides R-26 és 2.4.1 törzset használtam. Az R26 törzs karotinoidmentes, az abszorpciós spektrumából hiányoznak a karotinoidok sávjai, ezért folyadékkultúrájának színe jellemzően kék, míg a vadtípusú tenyészet színe vöröses barnás. A 2.4.1, melyet sokszor vadtípusú reakciócentrumként említenek, rendelkezik karotinoiddal, megvédve ezzel a fehérje komplexet a fotooxidációval szemben. A karotinoidot nem tartalmazó R26 törzs sejtjei fotoheterotróf nevelési körülmények között nevelkedtek, mivel érzékenyek a tápoldat oxigénkoncentrációjára.

A folyadékkultúrákhoz 1,5\%-os agaron nőtt masszív szúrt tenyészetekből vettünk mintákat a $10-15 \mathrm{~cm}^{3}$ szukcinát-tartalmú Siström-tápoldatot tartalmazó, jól zárható kémcsövekbe. A továbbtenyésztéshez $200-250 \mathrm{~cm}^{3}$, majd $1000 \mathrm{~cm}^{3}$-es üvegeket használtunk. Minden egyes átoltás után 4-6 órára sötétben tartottuk a sejteket, biztosítva, hogy az oldatban lévő összes oxigént felhasználják. Erre azért volt szükség, mert a tápoldatban maradt kismennyiségü oxigén fotoheterotróf nevelési körülmények között a sejtek egy részét elpusztítaná, lassítva a tenyészet 
növekedését. A sötétperiódus után a tenyészeteket fényre tettük a fotoheterotróf nevelési körülmények biztosítása céljából. A megvilágítás $40 \mathrm{~W}$ teljesítményü wolfram izzószálas lámpákkal történt, amelyeket kb. $20 \mathrm{~cm}$-re helyeztünk el a tenyészetektől. Az izzólámpák által termelt hő egyúttal biztosította az optimális, kb. $30{ }^{\circ} \mathrm{C}$ hőmérsékletet is. 4-5 napig állandó fényben történő tenyésztés után a sejteket lecentrifugáltuk (6000 x g, 20 perc), majd mosópufferrel (10 mM TRIS; $100 \mathrm{mM} \mathrm{NaCl}$ ) mostuk, és a felhasználásig $-20--25^{\circ} \mathrm{C}$-on lefagyasztva tároltuk (Nagy és mtsai., 1991). Literenként kb. 8 gramm baktériumtömeget tudtunk összegyüjteni.

\subsubsection{Reakciócentrumok preparálása}

A RC-ok preparálásához nagyobb mennyiségü, kb. 100 g vizes tömegü sejtre van szükség, amelyeket a preparálás elött többször átmostunk TRISpufferrel (10 mM TRIS; $100 \mathrm{mM} \mathrm{NaCl}$; pH 8,0). Hígítás után ultrahanggal feltörtük a sejteket. Az ultrahangos feltáráshoz SONOPLUS Ultrasonic homogenizer-t használtunk (Bandelin, Németország). Egy speciálisan a sejtfeltárásra tervezett, jégbe állított üvegedényben a készülék TT 13 titánfejét használva 1 órán át közel 100\% (kb. $70 \mathrm{~W})$ teljesítménnyel, impulzus üzemmódot használva (5 impulzus/periódus) ultrahangoztuk a sejteket. A számunkra szükségtelen sejtmaradványokat (sejtfal, feltöretlen sejtek) centrifugálással távolítottuk el (40000 x g, 10 perc), majd a felülúszót ultracentrifugáltuk (240000 x g, 90 perc). Az üledékben kapott kromatoforát finom ecsettel felszuszpendáltuk, és $0,45 \%$ LDAO detergenst tartalmazó TRIS-pufferrel kioldottuk a fehérjéket, amit újabb ultracentrifugálással választottunk el a nem szolubilizált részektől. A felülúszóból a RC-ot frakcionált ammónium-szulfátos kicsapással, majd DEAE

Sephacell anioncserélő oszlopkromatográfiával különítettük el. Az oszlopkromatográfia előtt a mintát dializálással sómentesítettük. A kromatográfia során szedett frakciókból azokat tartottuk meg, amelyekben az $\mathrm{OD}_{280 \mathrm{~nm}} / \mathrm{OD}_{800 \mathrm{~nm}}$ arány 1,2-1,5 között volt. A koncentráció és a tisztaság megállapítása után $U_{10}$ hozzáadásával a $\mathrm{Q}_{\mathrm{B}}$-aktivitást $90 \%$ felettire állítottuk be. Az ilyen módon izolált RC-at $-20{ }^{\circ} \mathrm{C}$-on tároltuk. 


\subsubsection{Porózus szilícium előállítása}

A porózus szilícium minták p-típusú bór-dópolt 500-550 $\mu \mathrm{m}$ vastagságú, 0,002-0,004 $\Omega \cdot \mathrm{cm}$ fajlagos ellenállású és (100)-ás krisztallográfiás orientációjú lapokból nedves elektrokémiai maratásos eljárással készültek. Az elektrolitot hidrogén-fluorid (48\%), etanol (98\%) és glicerol (98\%) alkotja 3:7:1 térfogatszázalékban (Agarwal és mtsai., 2003, 2004). A mikrokavitációs szerkezetben magas és alacsony porozitású rétegek váltakoznak (HL) ${ }_{\mathrm{x} 5} \mathrm{HH}(\mathrm{LH})_{\mathrm{x} 5}$ elrendeződésben, ahol $\mathrm{H}$ a magas, L az alacsony porozitású réteget jelöli. Minden réteg optikai vastagsága $\lambda / 4$ (az általam használt minták esetében $\lambda=700 \mathrm{~nm}$ ), míg a középen elhelyezkedő egymást követő két magas porozitású rétegnél $\lambda / 2$. Az első réteg magas porozitású, így biztosított a jó penetráció a makromolekulák számára.

A PSi lapok egy részét Vivechana Agarwal-tól (Universidad Autonoma del Estado de Morelos, Cuernavaca, Mexico) kaptam, illetve Gabriela Palestino laboratóriumában (Facultad de Ciencias Químicas, Universidad Autónoma de San Luis Potosí, San Luis Potosí, Mexico) magam készítettem.

\subsubsection{Szén nanocsövek előállítása}

Az amin-funkcionált egyfalú szén nanocsöveket Horváth Endre készítette Forró László laboratóriumában (Institute of Physics of Complex Matter, Ecole Polytechnique Fédérale de Lausanne, CH-1015 Lausanne, Svájc). A nagynyomású szénmonoxid atmoszférában készült (HiPco) szén nanocsövek tisztítása nedves oxidációs módszerrel történt, a következők szerint: 100 mg nyers HiPco SWCNT-

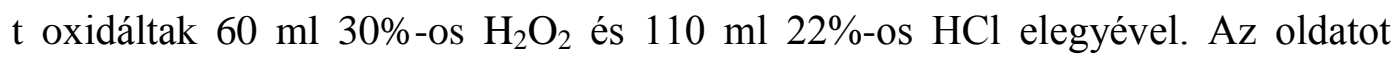
keverés mellett $70{ }^{\circ} \mathrm{C}$-on, 9 órán át folyamatos reflux alatt tartották. Ezt követően szobahőmérsékletüre hütötték, majd a nanocsöveket leszürték, és desztillált vízzel 7-es pH eléréséig mosták (Dorogi és mtsai., 2006). Végül $120{ }^{\circ} \mathrm{C}$-on, 30 percig szárították. A tisztított nanocsövek hozama 90\%, amit transzmissziós elektronmikroszkóppal (TEM) határoztak meg. Az egyfalú nanocsövek átlagos átmérője 1-5 $\mathrm{nm}$. 


\subsection{Biokompozitok előállítása}

\subsubsection{Növényi sejtek rögzítése szol-gél módszerrel}

\subsubsection{A szilikát mátrix szintézise}

A sejtek bekötését megelőzően ajánlott különböző összetételü szilika mátrixokat létrehozni, hogy megtaláljuk a sejtek immobilizálásához az optimális arányokat. Ebből a célból több különböző összetételü, sejteket nem tartalmazó mátrixot hoztam létre, hogy jellemezzem azok fizikai és kémiai tulajdonságait, mint például a pH-t, az ozmotikus nyomást és a zsugorodás mértékét (1. táblázat).

Nátrium-szilikátból $\left(\mathrm{Na}_{2} \mathrm{SiO}_{3}\right.$, Mercks, a továbbiakban NaSi) 1,5 M-os oldatot készítettem, majd fagyasztóba tettem. A gyantát (Acros) savas vízzel pH 0,5-1-re $(37 \% \mathrm{HCl}, \mathrm{Acros})$, majd $\mathrm{pH}$ 2-re állítottam be ( $\mathrm{HCl} 1 \mathrm{M}$, Sigma), és -4 ${ }^{\circ} \mathrm{C}$-ra hütöttem le. Közvetlenül a hütést követően összekevertem a nátriumszilikátot és a gyantát tartalmazó oldatokat, és szürőpapíron (VWR 417) szürtem át. Ezt követően tiszta szol állapotú szilikát oldatot kaptam. A mátrix összeállításához ezt az oldatot, illetve MTGS-t (metil-triglicerol-szilán), NaCloldatot $(0,6 \mathrm{~g} / 100 \mathrm{ml})$ és $\mathrm{KOH}$-oldatot $(5,6 \mathrm{~g} / 100 \mathrm{ml})$ használtam különböző arányban. MTGS-t és NaCl-ot hat különböző koncentrációban alkalmaztam. A preparáció folyamán fontos a pH és az ozmotikus nyomás pontos beállítása.

\begin{tabular}{ccccccc}
\hline Minta & $\begin{array}{c}\text { MTGS } \\
(\%)\end{array}$ & $\begin{array}{c}\text { NaSi } \\
(\mathrm{ml})\end{array}$ & $\begin{array}{c}\text { MTGS } \\
(\mathrm{ml})\end{array}$ & $\begin{array}{c}\mathrm{NaCl} \\
(\mathrm{ml})\end{array}$ & $\begin{array}{c}\mathrm{KOH} \\
(\mu \mathrm{l})\end{array}$ & $\begin{array}{c}\text { Gélesedés ideje } \\
(\text { perc })\end{array}$ \\
\hline 1 & 0 & 8 & 0 & 6 & 120 & 5 \\
2 & 3 & 8 & 0,35 & 5,6 & 110 & 5 \\
3 & 6 & 8 & 0,70 & 5,3 & 120 & 5 \\
4 & 11 & 8 & 1,50 & 4,5 & 110 & 5 \\
5 & 18 & 8 & 2,60 & 3,4 & 110 & 5 \\
6 & 33 & 8 & 6,00 & 0 & 90 & $>60$ \\
\hline
\end{tabular}

1. táblázat: A különböző MTGS koncentrációjú szilikát mátrixok összetétele. A táblázat minden minta esetében tartalmazza az MTGS, $\mathrm{NaSi}, \mathrm{NaCl}, \mathrm{KOH}$ mennyiségét, illetve a gélesedéshez szükséges időt. 
A gél elkészítése során az egyik legfontosabb lépés a pH pontos beállítása. Elöször igen savas, $\mathrm{pH} 2$ értékre van szükség, mivel itt található a prekurzor izoelektromos pontja. A gél létrejötte előtt azonban a pH-nak fel kell emelkedni 5,7-es értékre, mert a növényi sejtek számára ez a pH az optimális.

A preparálás végén minden mintából elkülönítettem 2 ml-t egy küvettába két napra. Ez a mennyiség elég volt ahhoz, hogy kellöképpen stabil legyen a minták struktúrája. Ezt követően kivettem őket, és minden második nap megmértem a térfogatukat. Így nyomon tudtam követni a minták zsugorodásának mértékét.

\subsubsection{A növényi sejtek rögzítése}

A sejtek immobilizálásához megfelelő környezet szükséges. A kompozit létrehozásához nátrium szilikát (a fent említett recept alapján), MTGS, MS 1x, MS 10x, KOH és a felnevelt sejtkultúra oldata szükséges. Három különböző MTGS koncentráció használatával készítettem három különböző mintát. Az arányokat és pontos mennyiségeket a 2. táblázat tartalmazza.

\begin{tabular}{cclllll}
\hline Minta & $\begin{array}{c}\text { NaSi 1,5 M } \\
(\mathrm{ml})\end{array}$ & $\begin{array}{l}\text { MTGS } \\
(\mathrm{ml})\end{array}$ & $\begin{array}{l}\text { MS 1x } \\
(\mathrm{ml})\end{array}$ & $\begin{array}{l}\text { MS 10x } \\
(\mathrm{ml})\end{array}$ & $\begin{array}{l}\text { KOH } \\
(\mu 1)\end{array}$ & $\begin{array}{l}\text { Sejtek } \\
(\mathrm{ml})\end{array}$ \\
\hline 1 & 16 & 0,6 & 5,4 & 1,6 & 765 & 4,4 \\
2 & 16 & 1,4 & 4,6 & 1,6 & 765 & 4,4 \\
3 & 16 & 5,2 & 0,8 & 1,6 & 765 & 4,4 \\
\hline
\end{tabular}

2. táblázat: A különböző MTGS koncentrációjú szilikát mátrixok összetétele Arabidopsis thaliana egész sejtek rögzítése esetén. A táblázat minden minta esetében tartalmazza a NaSi, MTGS, MS 1x és 10x, KOH és a sejtkultúra mennyiségét.

\subsubsection{RC/PSi kompozitok előállítása}

A RC immobilizálása a PSi felületén két különböző protokollal történt. Első esetben kémiai, majd ezt követően fizikai kötési eljárást alkalmaztam a fehérje komplexek rögzítéséhez. 


\section{Kémiai kötés keresztkötőkkel:}

Kezdetben a porózus szilícium minták használatánál sok gondot okozott, hogy a lapok könnyen oxidálódtak, és ezzel inhomogénné vált a PSi lapok felszíne. Ezt a problémát egy érdekes ötlet oldotta meg, mely során termális oxidáció által egy erős oxid-réteget hoztam létre a felszínen. Ez a réteg homogén és stabil, a későbbiekben könnyen kezelhetö.

A fehérje kémiai kötésekor egy háromlépéses kötési protokollt követtem, melynek első lépése a szilícium mikrokavitások (PSi) $900{ }^{\circ} \mathrm{C}-o n, 3$ percig történő termális oxidációja. Így lehetséges volt egységes oxidréteg létrehozása a szilícium lap felszínén. A PSi felszínének további funkcionalizálása a lapok szilanizálásával történik. Az 5\%-os 3-aminopropil-trietoxiszilán (APTES, Aldrich)/toluén oldatban 1 órán át inkubálódott a minta. A szilanizálást követően szabad amincsoportok válnak elérhetővé a PSi felszínén. A felszínhez nem kötődött APTES oldatot tiszta toluénnel, majd etanollal mostam le. A PSi lapot $\mathrm{N}_{2}$-áramban szárítottam, majd $110{ }^{\circ} \mathrm{C}$-os kemencébe helyeztem 15 percre. A RC-ot keresztkötőszer segítségével kötöttem kémiailag a PSi-hez. Az általam használt glutáraldehid (GTA) amin-csoporthoz célzottan kötődő homobifunkcionális keresztkötőszer. Két aldehid-csoporttal rendelkezik, ebből egyik az APTES szabad amin-csoportjához, míg a másik a RC egy hozzáférhetö lizin oldalláncához kötődik (Palestino és mtsai., 2008). 20 percig inkubálódott a minta 2,5\%-os GTA (Sigma) - 10\% PBS puffer oldatban (pH 7; foszfát puffer, 2,7 mM KCl, $137 \mathrm{mM}$ $\mathrm{NaCl}$, Sigma). Az inkubációs időt követően a nem kötött GTA-ot 10\% PBS pufferrel lemostam, majd, a kísérleti körülményeknek megfelelően, különbözö koncentrációjú RC-oldatot (10 mM TRIS; 0,03\% LDAO; pH 8,0) cseppentettem a PSi felszínére két órás inkubációs időre. A nem kötött reakciócentrumot PBS pufferrel mostam le.

\section{Peptidborítással segített kötés:}

A második módszer során a RC egy 12-mer peptid (szekvenciája SPGLSLVSHMQT) segítségével kapcsolódik a PSi-hez. Ez a peptid specifikus, igen erősen kötődik az általunk használt p-típusú PSi felületéhez, és egy erősen hidrofób felületet hoz létre (Estephan és mtsai., 2011). Az eljárás elsö lépésében a szilícium lapot sósavval deoxidáltam, majd $20 \mu \mathrm{M}$-os peptid-PBST (PBS-puffer, 0,1\% Tween 20) oldatban 2 órán át inkubáltam. A nem kötött peptidet PBST-vel 
távolítottam el a felszínről. Ezt követően cseppentettem a különböző koncentrációjú RC-oldatokat a felületre, szintén 2 órás inkubációs időre. A maradék, nem kötött reakciócentrumot PBS pufferrel távolítottam el. Ez a protokoll egy igen erős fizikai kötést biztosít a RC és a PSi között.

\title{
4.2.3. Reakciócentrum/szén nanocső kompozitok előállítása
}

\begin{abstract}
Amin-funkcionált egyfalú szén nanocsövek felületéhez glutáraldehid homobifunkcionális keresztkötőszer segítségével kötöttem hozzá a reakciócentrumot. Az 1-2 nm átmérőjü, 4 mg/100 ml koncentrációjú nanocső szuszpenzióból $800 \mu \mathrm{l}$-t féligáteresztő membránba helyeztem, és kb. fél napig foszfát pufferben $(\mathrm{pH} 6,5)$ dializáltam. A dializálás során a minta és a dializáló oldat között egyensúlyi koncentráció jött létre azokra a komponensekre vonatkozóan, melyeket a féligáteresztő membrán átenged. Elsődleges cél a rendszerből eltávolítani a felesleges detergenst vagy egyéb kisméretü komponenseket (következő lépésben a GTA keresztkötőszert).

Ezt követően egy órás ultrahangozással (Transsonic 310) biztosítottam a homogén nanocső szuszpenziót. Az így kapott nanocső szuszpenzióhoz $50 \mu \mathrm{l}$ 50\%-os glutáraldehidet adtam, majd 10 percig 400 rpm-en mágneses keverővel kevertettem. A nem kötött glutáraldehidet 20 perces dializálással távolítottam el a szuszpenzióból (foszfát puffer, $\mathrm{pH}$ 6,5). Ezt követően 100 $\mu$ l RC-t (c=64 $\mu \mathrm{M}$ ) tettem a szuszpenzióba, és két órán át dializáltam foszfát pufferben $(\mathrm{pH} \mathrm{7,0)}$.

A kapott kompozitot addig mostam, amíg a felülúszó már nem tartalmazott RC-ot, tehát az összes nem kötődött RC-ot eltávolítottam a komplexböl (több alkalommal foszfát pufferrel 20 percig centrifugáltam (10000 rpm), majd szuszpendáltam). A felülúszót minden esetben pipettával óvatosan eltávolítottam, és detergenst tartalmazó foszfát pufferrel $(\mathrm{pH} 7,0 ; 0,03 \%$ LDAO) az eredeti térfogatra hígítottam. A felülúszó spektrumát UNICAM UV4 típusú spektrofotométerrel mértem. Ezt a lépést addig ismételtem, amíg a mért spektrum alapján a felülúszó már nem tartalmazott RC-ot. Így lehetséges volt a szén nanocsőhöz nem, vagy csak fizikailag kötődött RC eltávolítása a szuszpenzióból.
\end{abstract}


Az így kapott szuszpenzióból meghatározott mennyiségeket üveglapra cseppentettem, és nitrogén áramban szárítottam.

\subsection{Vizsgálati módszerek}

\subsubsection{Oximetria}

A rögzített növényi sejtek fiziológiai aktivitását az oxigén fogyasztásuk mérésével határoztam meg, amelyhez Clark cellát (Oxy-labmanufactured, Hansatech Instruments) használtam. Ez az eszköz modern módon képes a fotoszintetikus aktivitás és respiráció mérésére úgy, hogy a keletkezett oxigén mennyiségét méri. A vizsgálat során $500 \mathrm{mg}$ monolitikus, tehát egységes és stabilan összetartó gélt használtam $\left(3 \mathrm{~mm}^{3}\right)$, amit $1 \mathrm{ml}$ Murashige és Skoog tápoldathoz adtam (MS növekedést serkentő táptalaj (Murashie and Skoog, 1962)). A növényi sejtszuszpenzió aktivitását immobilizálás előtt is megmértem, és a későbbiekben ezt tekintettem referenciának (100\%-nak).

\subsubsection{Egyensúlyi abszorpciómérések}

A RC szuszpenzió abszorpciós spektrumát UNICAM UV4 típusú spektrofotométerrel határoztam meg. A mérés során a spektrofotométer közeli mintahelyzetét használtam, hogy lecsökkentsem a fényszórásból adódó mérési hibát. Mivel a RC komplex jellemző abszorpciós sávjai (az összfehérje abszorpcióját is figyelembe véve) egymástól viszonylag távoli hullámhossz tartományokban vannak, az UV tartománytól a közeli infravörös tartományig fel kellett vennem a spektrumot $(250 \mathrm{~nm}-900 \mathrm{~nm})$. A mérésekhez kvarcküvettát használtam.

A RC tisztaságát az $\mathrm{OD}_{280 \mathrm{~nm}} / \mathrm{OD}_{800 \mathrm{~nm}}$ arány meghatározásával jellemeztem (lásd a „Reakciócentrumok preparálása” fejezetet). A koncentrációt az $\varepsilon_{800}=280$ $\mathrm{M}^{-1} \mathrm{~cm}^{-1}$ extinkciós koefficiens alapján határoztam meg, a Beer-Lambert törvény alkalmazásával. 


\subsubsection{A fotokémiai/-fizikai aktivitás meghatározása abszorpcióváltozás kinetikai mérésével}

\subsubsection{Az abszorpcióváltozás mérése}

A RC-ok fényfelvillanás által gerjesztett oldatbeli abszorpcióváltozását házilag összeállított egysugaras spektrofotométerrel mértem (7. ábra, Tandori és mtsai., 1995). A nem gerjesztő hatású mérőfényt egy stabilizált tápegységgel táplált, $50 \mathrm{~W}$-os, 12 V-os autóizzó szolgáltatta, amelyet egy monokromátor (Jobin Yvon) belépő résére fókuszáltam, a kilépő fényt pedig egy fényzáron át a küvettatartóban levő mintára élesítettem. A mintán áthaladó fényt egy fotoelektron-sokszorozó (Hamamatsu R928) fotokatódjára képeztem le. A telítési gerjesztést egy xenon villanólámpa (EG\&G FX200, $\left.t_{1 / 2}=8,5 \mu \mathrm{s}\right)$ biztosította, amelyből a fény egy keresztezett optikai szürőn át érte el a mintát. A megmaradt vörös sáv elegendő volt a telítési gerjesztéshez. A fotokatód elé széles sávú keresztező szürőt tettem, hogy védje a fotoelektron-sokszorozót az erős gerjesztő fényimpulzussal szemben. A fényfelvillanás előtti stacionárius állapot kiegyenlítésére $100 \mathrm{mV}$ kiegyenlítő (offset) feszültséget kapcsoltam a fotokatódra, amit a mérőfény hatására a munkaellenálláson $(10-100 \mathrm{k} \Omega$ ) fellépő feszültséggel a flash előtt kiegyenlítettem. Az analóg erősítő jelét 3206B típusú PicoScope-pal digitalizáltam, amelyet laptop számítógéppel vezéreltem USB csatlakozón keresztül.

$\mathrm{Az}$ első gerjesztés hatására létrejövő töltésstabilizálódást a $\mathrm{P}^{+} \mathrm{Q}^{-} \rightarrow \mathrm{PQ}$ töltésrekombináció nyomonkövetésével vizsgáltam 430 és 860 nm-nél, ahol az impulzusgerjesztés után keletkező $\mathrm{P}^{+}$visszaredukálódását mértem.

Porózus szilícium lapok esetében a berendezést speciális elrendezésben, reflexiós módban használtam, mivel ezek a minták nem fényáteresztőek. A berendezés felépítését a 7 . ábra mutatja, amelyen szaggatott vonallal jelöltem a berendezés reflexiós méréshez történt átrendezését. 


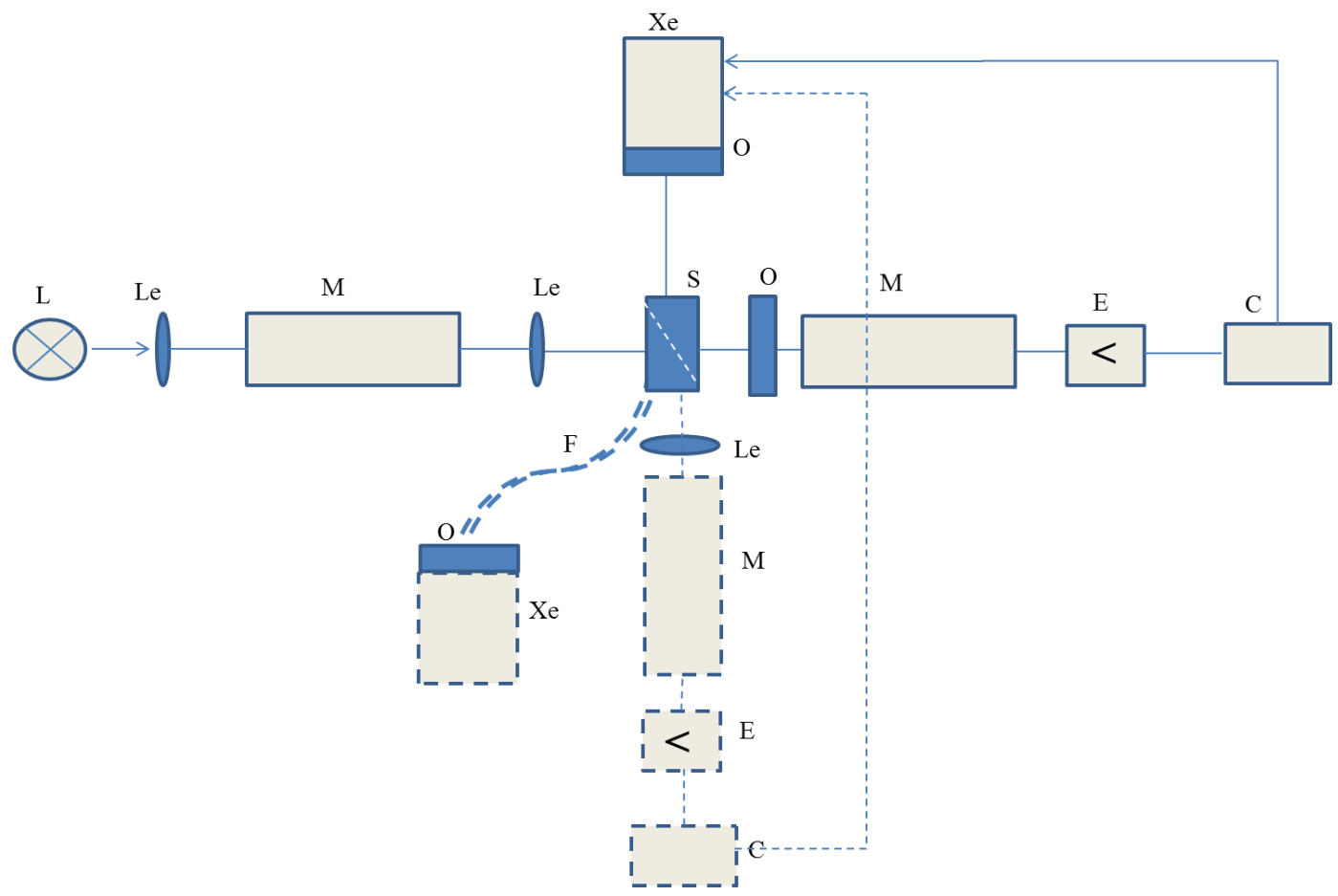

7. ábra A fényindukált abszorpcióváltozást mérő készülék blokkdiagrammja. Szaggatott vonal jelöli a készülék reflexiós módban alkalmazott elrendezését. L: halogén autoizzó $(50 \mathrm{~W}, 12 \mathrm{~V})$, Le: lencse, M: monokromátor, S: minta, F: optikai szál, Xe: xenon villanólámpa, O: optikai szürő, E: erősítő, C: pikoszkóp.

\subsubsection{Abszorpcióváltozás adatainak kiértékelése}

Töltésszétválasztás egyetlen telítési fénygerjesztést követően

A RC-ban lejátszódó fényindukált töltésszétválasztás kinetikájának és energetikájának jellemzésére az abszorpcióváltozás mérése rutinszerüen használható (Tandori és mtsai., 1991, 1995; Lakatos és mtsai., 2002). A P/P elsődleges elektrondonor és a $\mathrm{Q} / \mathrm{Q}^{-}$akceptor komplex kinonjai redoxállapotairól általában a 430, 450, 603, 860 nm-nél, illetve a BPheo 771 nm-nél mért abszorpcióváltozás kinetikája tájékoztat (Nagy és mtsai., 1999, 2004; Tandori és mtsai., 1995; Tiede és mtsai., 1996).

A vizsgált reakciók exponenciális függvénnyel írhatóak le. A kinetikák sokszor több exponenciális összegeként kezelhetők:

$$
\mathrm{A}_{t}=\sum_{i=1}^{n} \mathrm{~A}_{i} \cdot \mathrm{e}^{-k_{i} \cdot t}
$$


ahol $A_{\mathrm{t}}$ az amplitúdó időfüggése, $A_{\mathrm{i}}$ az i-edik komponens amplitúdója a $t=0 \mathrm{~s}$ időpontban, $k_{\text {i }}$ pedig a sebességi állandója.

Többszörös töltésszétválasztás

Folytonos fénnyel történő gerjesztés esetén a RC fotociklusa során folyamatos az átfordulás mind a donor, mind az akceptor oldalon. Ez azt jelenti, hogy az oxidált donormolekulák és a kétszeresen redukált, ún. dihidrokinol molekulák $\left(\mathrm{QH}_{2}\right)$ leválnak a RC-ról, és a helyükre redukált citokróm, illetve oxidált kinon kötődik.

A fotociklus nyomon követésére megbízható módszer a citokróm fotooxidációjának meghatározása az 550 nm-nél mért abszorpció fényindukált változásából (Kleinfeld és mtsai., 1984; Osváth és mtsai., 1996). Erre a célra a baktériumsejtekben természetesen előforduló $c_{2}$-típusú citokrómok mellett más szervezetekből (pl. élesztőből vagy emlősökből) származó citokróm is használható). A RC/PSi kompozitokon végzett vizsgálataimhoz lószívből származó citokróm $\mathrm{c}_{2}$-t (Sigma) használtam. A szilícium lapokat egy puffert (10 mM TRIS; $100 \mathrm{~m} \mathrm{M} \mathrm{NaCl;} \mathrm{0,03 \%} \mathrm{LDAO;} \mathrm{pH} \mathrm{8,0)} \mathrm{tartalmazó} 1 \mathrm{~cm} \mathrm{x} 1 \mathrm{~cm}$ spektroszkópiai küvettába helyeztem Xe gerjesztő fénnyel szemben. A gerjesztés ismétlési frekvenciáját $1 \mathrm{~Hz}-$ re állítottam. A PSi-hez kötött $\mathrm{RC}$ által oxidált citokróm $\mathrm{c}_{2}$ mennyiségét a citokróm redukált és oxidált formájának különbségi extinkciós koefficiense alapján határoztam meg:

$$
\varepsilon_{\mathrm{red}}-\varepsilon_{\mathrm{ox}}=21,1 \pm 0,4 \mathrm{mM}^{-1} \mathrm{~cm}^{-1} .
$$

A citokrómot nátrium-aszkorbáttal redukáltam a mérések előtt, az abszorpciós spektrum ellenőrzése mellett. Az akceptor oldalt vízben oldékony $\mathrm{UQ}_{0}$-val (2,3-metoxi-5-metil-1,4-ubikinon, Sigma) állítottam helyre.

\subsubsection{Atomerő mikroszkópos vizsgálatok}

Az Atomerő Mikroszkópos (AFM) képek felvétele egy Molecular Force Probe 3D vezérlöszerkezettel (Asylum Research, Santa Barbara, CA, USA) ellátott Asylum MFP-3D fej segítségével, száraz körülmények között történt. A 
képek tapogatómódban, derékszögü szilícium tartókaros, 10 nm-nél kisebb, kb. 7 nm sugarú heggyel (Olympus Microcantilever, OMCL-AC240TS) készültek. A felvételek pásztázási frekvenciája $1 \mathrm{~Hz}-$ es volt, 512 x 512 képponttal digitalizálva. Az AFM vizsgálatokhoz a minta előkészítését és az adatok kiértékelését én, míg a méréseket Nagy Krisztina végezte el Dr. Váró György (MTA SZBK) laboratóriumában.

\subsubsection{Pásztázó elektronmikroszkópos vizsgálatok}

A pásztázó elektronmikroszkópos (SEM) felvételek Hitachi S-4700 típusú II FE-SEM müszerrel készültek 5-15 kV gyorsító feszültséggel. A mintákat a mérést megelőzően elektromosan vezető szénszalaggal ragasztottam fel a mintatartóra, majd $\mathrm{Au} / \mathrm{Pd}$ réteggel vontam be öket Ar atmoszférában. Az elemanalízis energia diszperzív röntgensugár diffrakció módszerrel (EDX) történt RÖNTEC XFLASG Detektorral 3001 és Silicon Drift Detektorral (SDD). A méréseket az SZTE TTIK elektronmikroszkóp laboratóriumában végeztem, a felvételek elkészítésében Németh Zoltán volt a segítségemre.

\subsubsection{Reflexiometriás vizsgálatok}

A reflexiós spektrumokat Bruker 66V Fourier Transzformációs Infravörös spektrofotométerrel vettem fel, Bruker A 510, $11^{\circ}$ Tükör Reflexiós Egység használatával (Montpellier Département Semiconducteurs, Matériaux et Capteurs laboratóriumban). A PSi mintákat wolframszálas égővel világítottam meg, a visszavert sugarat szilícium diódadetektor detektálta. A mért spektrumot 25000$9000 \mathrm{~cm}^{-1}$ (400-1100 nm) tartományban vettem fel a PSi-felszín kezelésének minden lépését követően. A spektrumok 100 felvétel átlagából születtek $2 \mathrm{~cm}^{-1}$ felbontásban (Estephan és mtsai., 2011; Thompson és mtsai., 2010). 


\subsubsection{Szinglet oxigén meghatározása}

1,3-difenilizobenzofurán (DPBF) festéket használtam a RC/SWCNT kompozitban fénygerjesztést követően keletkező szinglet oxigén detektálásához. A kísérlet során a DPBF spektrális változását mértem először egy modell rendszerben, amelyben a szinglet oxigént metilénkék generálta (Stracke és mtsai., 1999), majd RC szuszpenzióban szén nanocső nélkül, és szén nanocsővel egyaránt. A megvilágítást követően a rendszerben keletkező szinglet oxigén a DPBF-fel specifikus reakcióba lép, melynek hatására az izobenzofurán $\pi$ elektronsávrendszere sérül, o-dibenzoilbenzén (DBB) keletkezik (lásd, 8. ábra), így a DPBF 420 nm-es abszorpciós sávjában csökkenés jelentkezik (Amat-Guerri és mtsai., 1996).

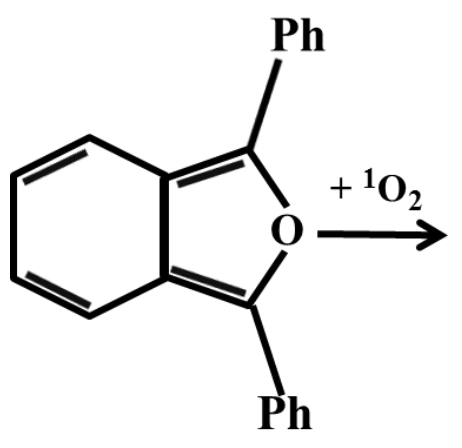

DPBF

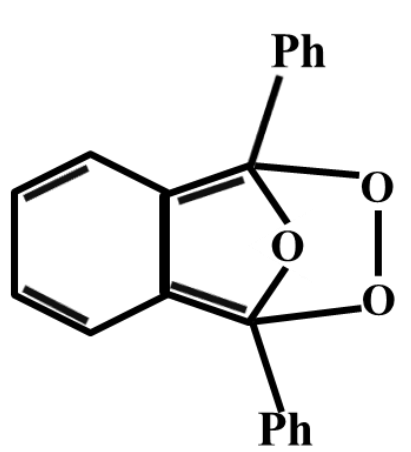

Ph

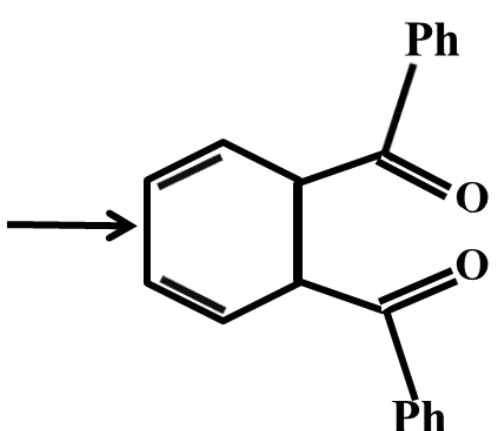

DBB

8. ábra A difenilizobenzofurán (DPBF) reakciója szinglet oxigénnel (Zhang és Li, 2011)

A DPBF-et tartalmazó metilénkék oldatot, majd később RC és RC/CNT szuszpenziókat minden esetben egy fél centiméteres küvettában vörös fénnyel (1>620 nm) világítottam meg. Minden 15. percben a teljes abszorpciós spektrumot felvettem UNICAM UV-4 kétsugaras spektrofotométerrel, majd az abszorpció intenzitását ábrázoltam a besugárzási idő függvényében. 


\section{Eredmények és kiértékelésük}

\subsection{Egész növényi sejtekkel létrehozott kompozitok jellemzése}

\subsubsection{Morfológiai jellemzés}

A különböző összetételü, növényi sejtet még nem tartalmazó szilikát mátrixok mikroszkópos vizsgálatát aerogél létrehozását követően végeztem el. Az aerogélt a legkisebb sűrűségű szilárd anyagként tartják számon. Angolul fagyott füstnek is nevezik. Létrejöttéhez gyakorlatilag a gélben található folyadékot kell gáznemü anyagra cserélni. Ehhez a mintákat először abszolút etanolba tettem, majd ezt követően a maradék etanolt $\mathrm{CO}_{2}$ abszorpcióval távolítottam el. Így lehetséges volt úgy eltávolítani a pórusokban lévő etanolt, hogy a minta sértetlen maradjon. A SEM képeken (9. ábra) látszik, hogy a gél struktúrája a szilícium részecskék aggregációjával jön létre.

A mikroszkópos felvételek alapján úgy tünik, hogy nagyobb MTGS koncentráció mellett a pórusméret jelentősen csökken, és a pórusok fala is vastagabb, tehát a porozitás is kisebb. 

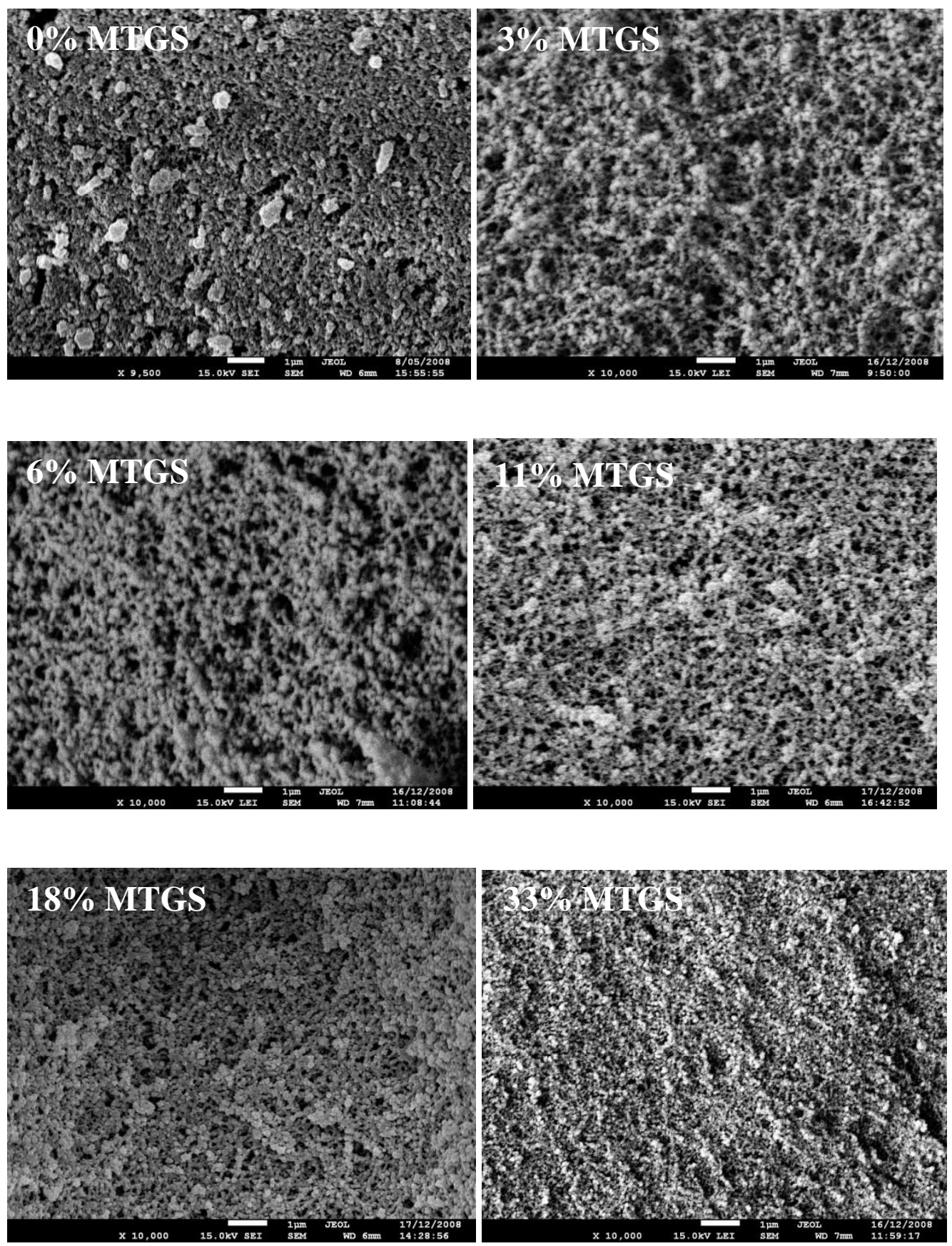

9. ábra Pásztázó elektronmikroszkópos felvételek a különböző, az ábrán látható MTGS koncentrációkat tartalmazó hibrid gélekről

A gélek zsugorodásának vizsgálata során a mintákat vízzel mostam. A 3. táblázatban látható, hogy az első pár napban a zsugorodás valamivel kisebb volt azokban a mintákban, amelyek több MTGS-t tartalmaztak. Ezt követően azonban egy nagy emelkedés figyelhető meg ugyanezen minták \%-os zsugorodásában (11, 18 és 33\% MTGS). Ennek az lehet a magyarázata, hogy a hidrofób felszín a víz 
nagyobb mértékü evaporációját okozhatja, megnövelve ezzel a minta zsugorodásának mértékét.

\begin{tabular}{lcccccc}
\hline $\begin{array}{l}\text { Napok } \\
\text { száma }\end{array}$ & 0\% MTGS & $3 \%$ MTGS & 6\% MTGS & 11\% MTGS & 18\% MTGS & $33 \%$ MTGS \\
\hline 2 & $97.25 \%$ & $97.05 \%$ & $97.15 \%$ & $98.95 \%$ & $99.05 \%$ & $99.05 \%$ \\
4 & $97.05 \%$ & $94.25 \%$ & $96.15 \%$ & $97.95 \%$ & $97 \%$ & $95.95 \%$ \\
7 & $97.15 \%$ & $92.95 \%$ & $93.95 \%$ & $96 \%$ & $94.90 \%$ & $91.65 \%$ \\
11 & $98.95 \%$ & $91.50 \%$ & $92.75 \%$ & $92.75 \%$ & $91.40 \%$ & $87.35 \%$ \\
15 & $99.05 \%$ & $90.80 \%$ & $92.10 \%$ & $89.90 \%$ & $87.05 \%$ & $83.65 \%$ \\
28 & $99.05 \%$ & $82.25 \%$ & $86.15 \%$ & $71.20 \%$ & $65.50 \%$ & $58 \%$ \\
\hline
\end{tabular}

3. táblázat A gélek zsugorodása az eltelt napok függvényében. 100\%-os térfogatnak a 0 . napon mért értéket tekintettem.

\subsubsection{A szilikagélben rögzített növényi sejtek aktivitása}

A szilikagélben rögzített sejtek életképességének vizsgálata sötétben történő légzési aktivitásuk mérésével történt. A növényi sejtek immobilizálásához megfelelő pórusméret szükséges, így csak négy különböző MTGS koncentráció mellett történt az immobilizálásuk: 0\% MTGS, 3\% MTGS, 6\% MTGS és 18\% MTGS. A 10. ábra a sejtek oxigénfogyasztásának mértékét mutatja a különböző összetételü gélekben. A fogyott oxigén mennyiségéből következtetni lehet az aktív sejtek számára. A mátrix által létrejött zárt rendszer megváltoztatja a sejtszintü anyagcserét. A sejtek csapdázását követően kezdetben enyhe csökkenés figyelhető meg az aktivitásukban. Ennek a lehetséges oka a sejtek környezetének drasztikus megváltozása, hiszen immobilizálást követően egy porózus, zárt rendszerbe kerültek, ahol a felszín tulajdonságai - pl. pH, hidrofobicitás -, a limitált tápanyagmennyiség, valamint a pórusméret együttesen befolyásolja a sejtaktivitást. Úgy tünik azonban, hogy a sejtek pár nap alatt sikeresen adaptálódnak az új környezethez, amit egyértelmü emelkedés jelez a 10. ábrán. A legnagyobb aktivitás a 6\%-os MTGS koncentráció mellett figyelhető meg, de mind a három minta mutat aktivitást még 24 nap eltelte után is. 


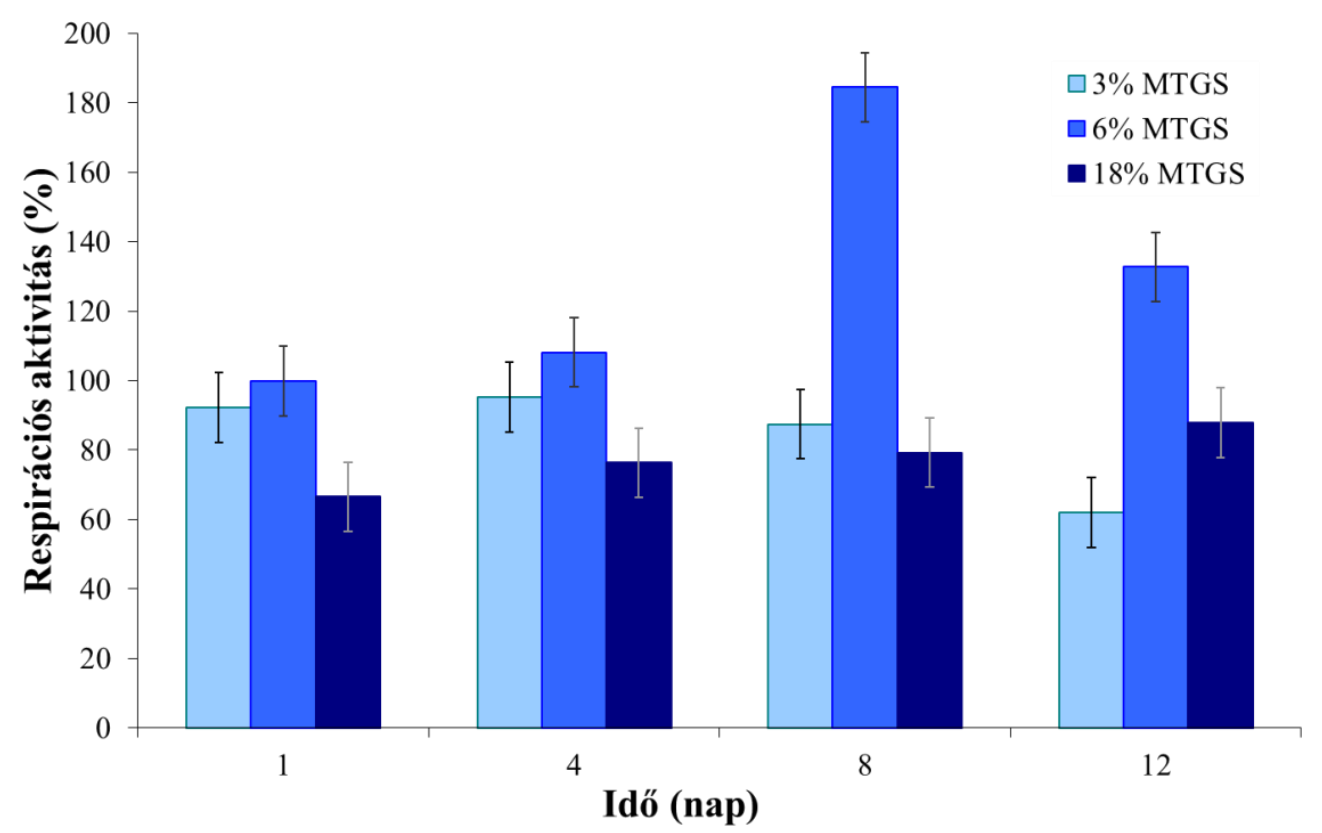

10. ábra A rögzített növényi sejtek respirációs aktivitása az eltelt napok függvényében különböző MTGS-t tartalmazó gélekben

A különbség a különböző minták aktivitásában több okból adódhat. Fontosak lehetnek a felszíni tulajdonságok, mint a felületi töltés, amit a $\mathrm{pH}$ is befolyásol és a hidrofobicitás, de a mérések alapján úgy tünik, hogy a pórusméret az a tényező, amely a leginkább befolyásolja a sejtek aktivitását. 6\%-os MTGS koncentráció mellett érhető el a legnagyobb pórusméret a SEM felvételek alapján, és a sejtek aktivitása is ennél az értéknél mutatkozik a legnagyobbnak. Ezen kívül úgy tűnik, hogy a sejteket körülölelő, megfelelő paraméterekkel bíró gélstruktúra elősegíti a tápanyag áramlását, amely alapvető a sejtaktivitás megőrzésében.

Fontos azonban leszögezni, hogy az oxigénfogyasztásból származó adatok nem nyújtanak információt a sejtek egyéb létfenntartó tulajdonságairól, például a sejtek növekedéséről és osztódásáról. Utóbbi tulajdonságok elveszhetnek attól függetlenül, hogy a sejtek respirációja megmarad. A sejtek életképességét én idő hiányában nem vizsgáltam, de a későbbiekben történtek erre vonatkozó mérések a kutatócsoportban (Université de Namur, FUNDP, Prof. Bao Lian Su laboratóriuma). 


\subsection{RC/PSi kompozitok jellemzése}

\subsubsection{Morfológiai jellemzés}

A PSi pórusméretének és réteges szerkezetének jellemzéséhez AFM és SEM képek készültek felületre merőleges és oldalnézetből, az immobilizálási eljárás előtt és után egyaránt.

A RC bekötődését megelőzően készült AFM képek alapján (11. ábra A, B) arra lehet következtetni, hogy kezelést követően a pórusméret elegendően nagy (50-90 nm) ahhoz, hogy hatékony penetrációt biztosítson a kb. 10-11 nm átmérőjü (Dorogi és mtsai., 2006; Ohmori és mtsai., 2008) fehérje komplexnek. A kémiai kötést követően az AFM felvétel egy egységesebb, simább felszínt mutat nagyobb

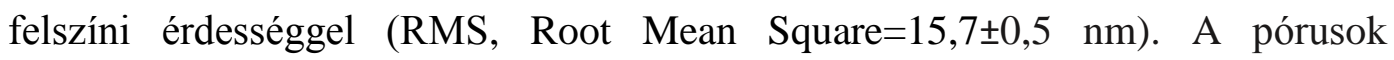
egybeolvadásával az átlagos pórusméret 70-150 nm-es lett, könnyü penetrációt biztosítva a RC-nak. A RC immobilizálását követően a felszín tulajdonságai megváltoztak, az érdessége megnőtt.
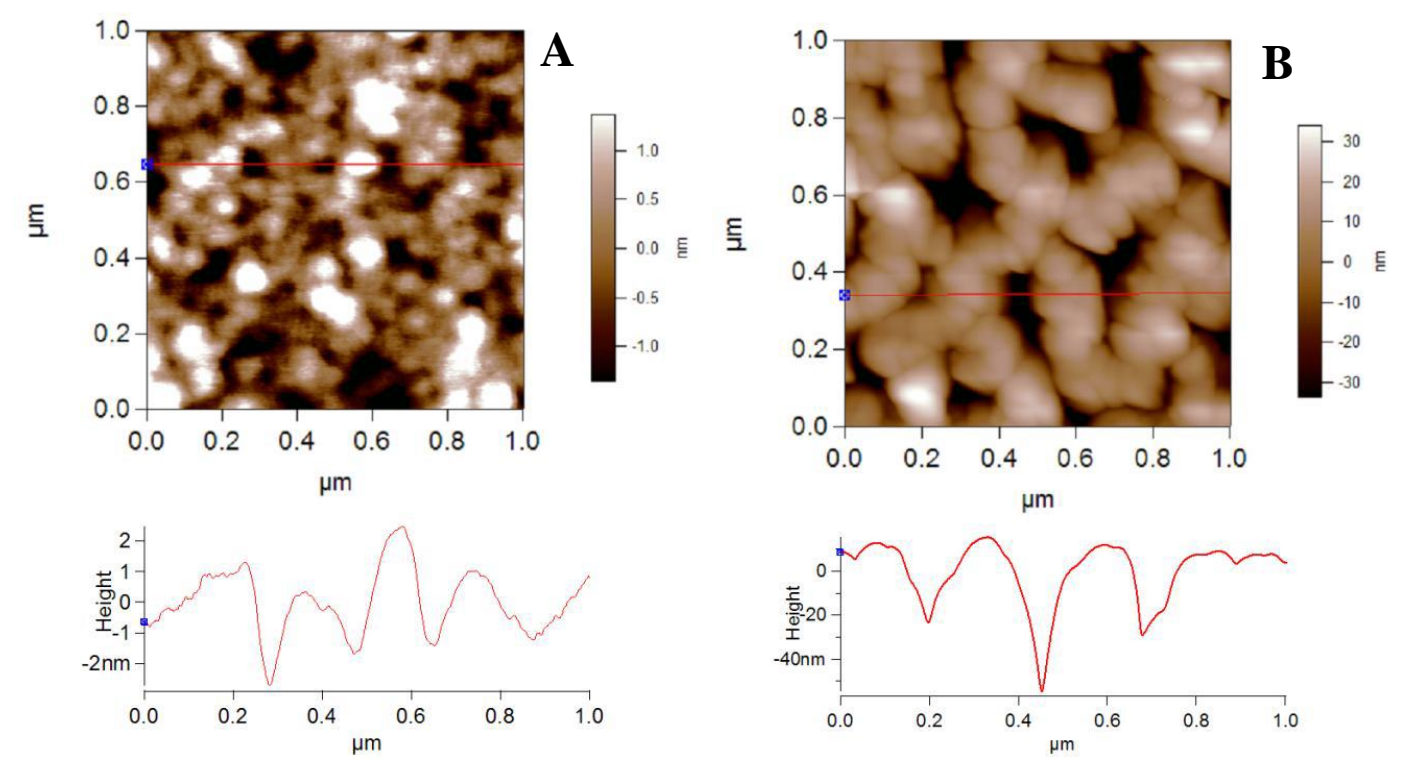

11. ábra AFM felvétel $(1 \times 1 \mu \mathrm{m})$ felületi topográfia és magasságkép a kezeletlen PSi (A) és RC/PSi kompozitról (B)

A pásztázó elektronmikroszkópos (SEM) felvételek oldalnézetből készültek. Ezeken a képeken nagyon jól látható a PSi réteges, $\lambda / 4$ optikai vastagságú 
szerkezete. Középen elkülönül a nagy porozitású vastagabb aktív réteg, amelynek optikai vastagsága $\lambda / 2$ (12. ábra $\mathrm{A})$. Az immobilizálás utáni SEM képeken megjelenik a RC borítás a PSi felületén (12. ábra B).
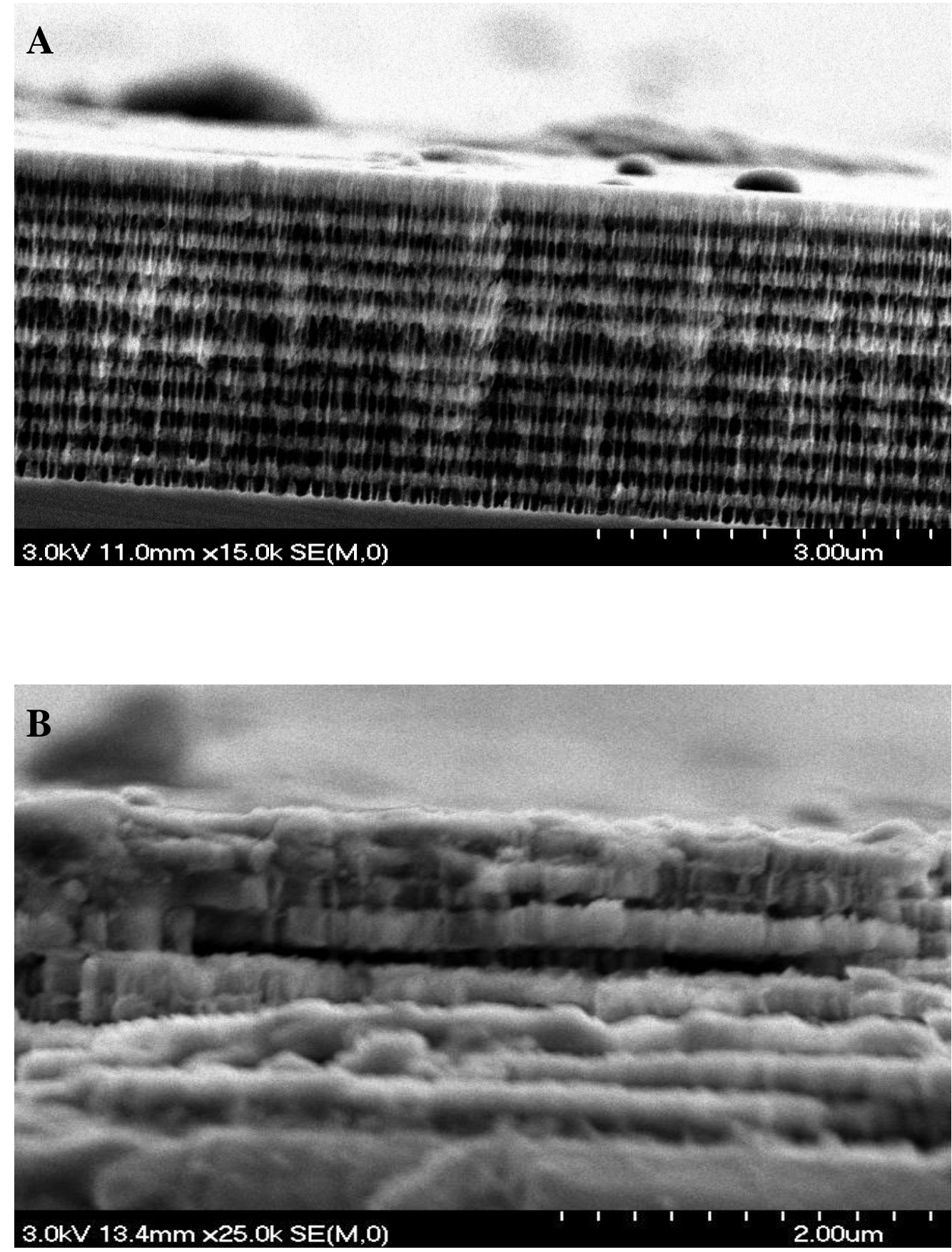

12. ábra SEM képek a kezeletlen (A) és a RC-ot tartalmazó (B) PSi lapokról oldalnézetböl. A sötét részek a nagy, a világos részek a kis porozitású rétegekhez tartoznak. 
A mintákon elemanalízist is végeztem energiadiszperzív röntgensugár spektroszkópiával (EDX, 13. ábra).
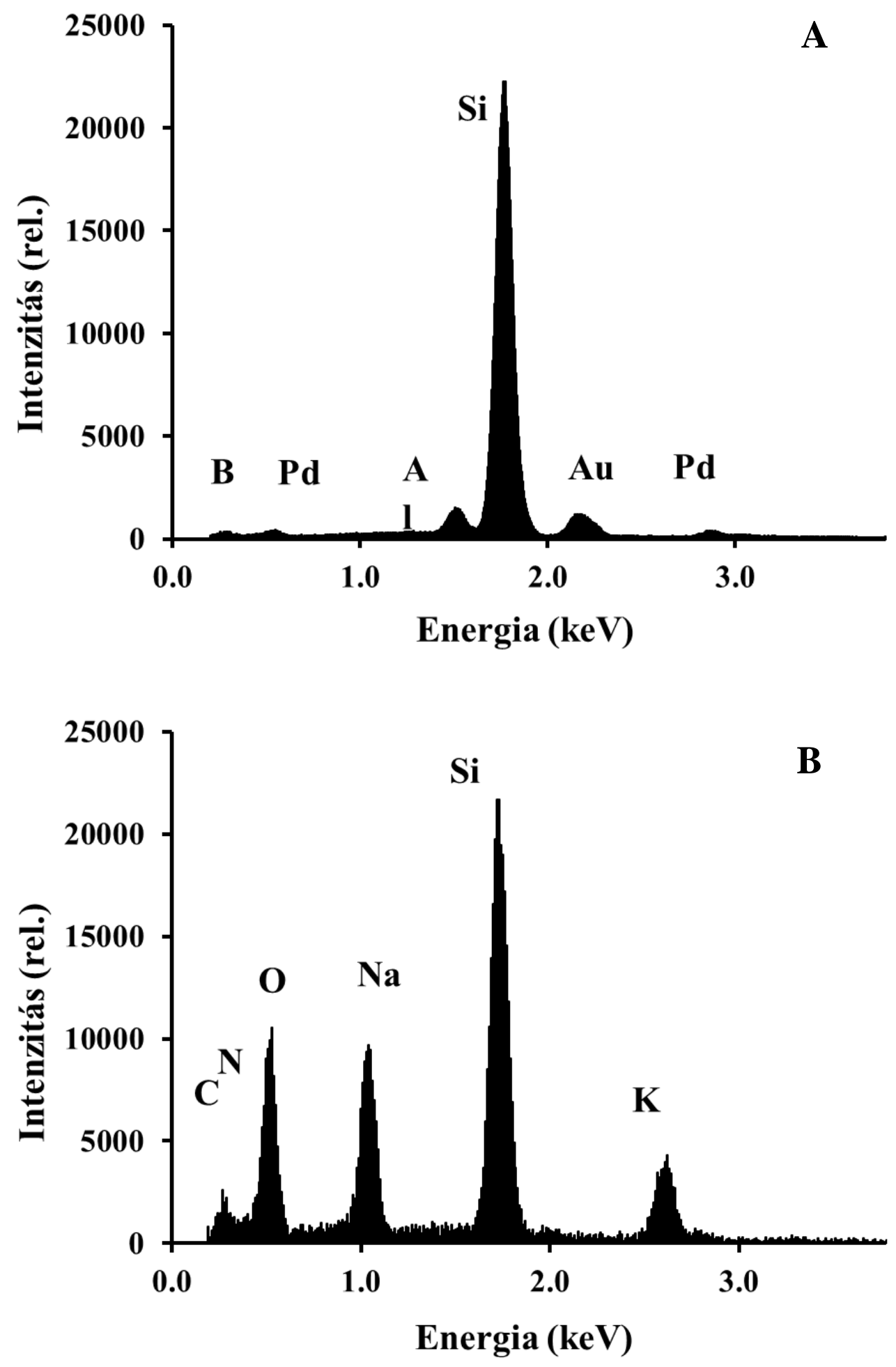

13. ábra Elemanalízis (EDX) eredménye kezeletlen (A) és $6 \mu \mathrm{M}$ RC-oldattal inkubált (B) PSi mintán. Az ábrán az egyes csúcsokhoz tartozó elemeket feltüntettem. 
A referencia minták esetében, melyek nem tartalmaztak RC-ot, a fehérjékben megtalálható $\mathrm{C}, \mathrm{N}, \mathrm{O}$ elemek jellemző csúcsai hiányoztak (13. ábra A). A RC rögzítését követően mindkét kötési mechanizmus esetén megjelent a három specifikus csúcs, bizonyítva, hogy a RC sikeresen bejutott a szilícium pórusrendszerébe (13. ábra B). Az egyéb kisebb intenzitású csúcsok, mint az Au, Pd, Al a mintaelőkészítés során, például a mintatartóból kerülhettek a mintába.

\subsubsection{A RC PSi struktúrába történő beépülésének optikai vizsgálata}

A PSi specifikus reflexiós spektrumának segítségével lehetséges nyomon követni a pórusokba kötődött molekulák mennyiségét (14. ábra). A PSi, réteges porózus szerkezetéből adódóan, olyan reflexiós spektrummal bír, amely rendelkezik egy kitüntetett rezonancia módussal. Ez a csúcs a törésmutató és a felszíni tulajdonságok változásának függvényében eltolódhat a vörös és kék tartományba egyaránt. Az eltolódás mértéke függ a bekötött molekulák (pl. RC) mennyiségétől, így összehasonlítható a RC immobilizálása során használt két különböző kötési eljárás hatékonysága.

A reflexiós spektrum mérése Fourier Transzformációs Infravörös (FTIR) spektroszkópiával történt, amely során a minta felületéröl visszavert fény intenzitását mértem egy adott beesési szögben. A mért jel intenzitása, amely a lapka felületéről és alsóbb rétegekről is származik, nagyban függ a visszavert mérőfény beesési szögétől, a törésmutatótól és a rétegvastagságtól. A rezonanciacsúcs pozíciója igen érzékeny a törésmutató változására, így a biomolekulák okozta törésmutatóváltozás alapján hatékonyan mérhető az immobilizált molekulák mennyisége. Minél nagyobb a bekötött molekulák száma, annál nagyobb a rezonancia-csúcs pozíciójának eltolódása. 


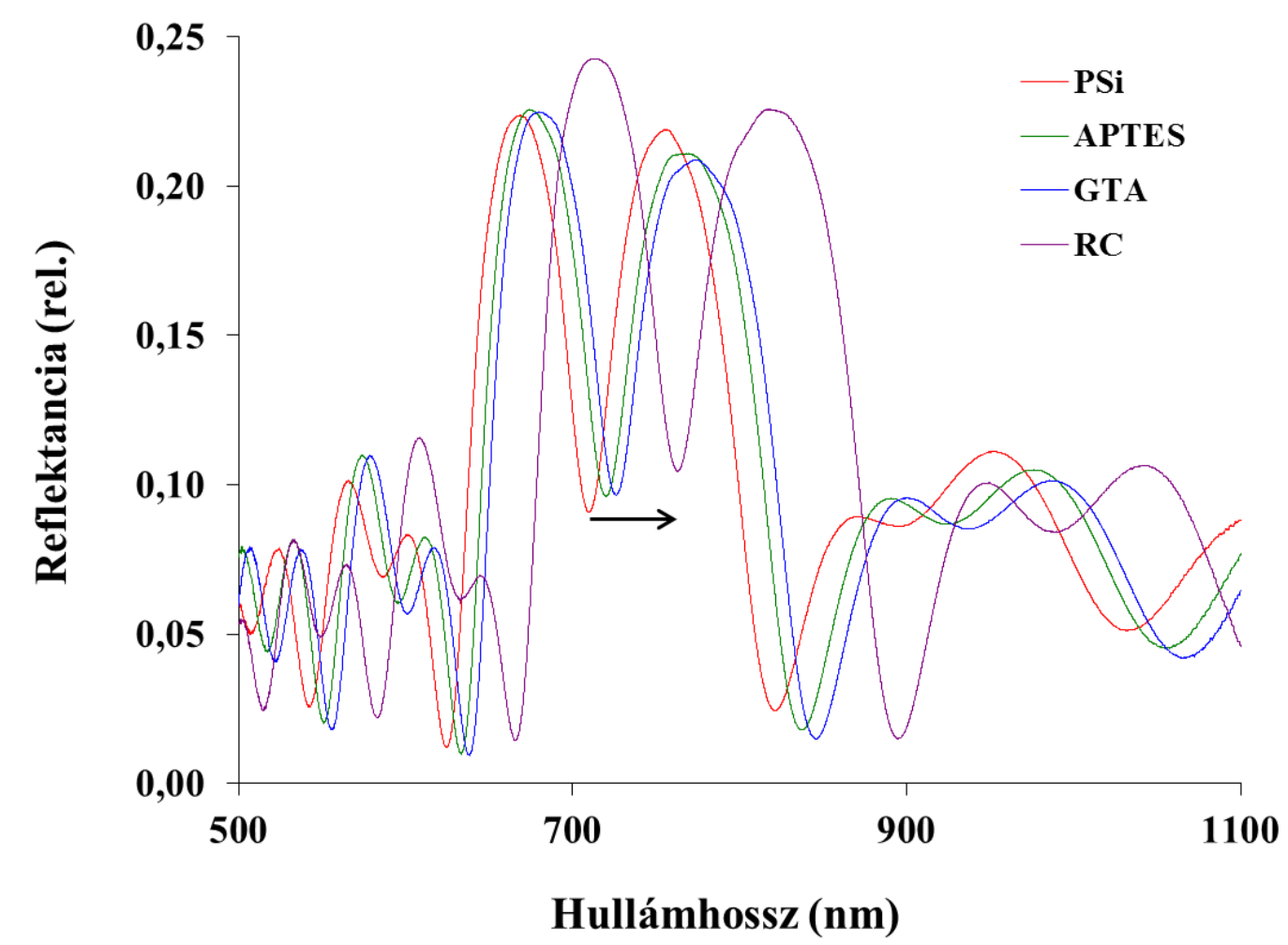

14. ábra A PSi reflexiós spektruma a RC fizikai kötési procedúrájának egyes lépéseit követően. A RC inkubációs koncentrációja $6 \mu \mathrm{M}$. A nyíl a RC kötését követően a vörös szín felé való eltolódást jelzi. PSi: kezeletlen PSi lap; APTES; GTA; RC: a funkcionálás egyes lépéseit követő spektrumok.

A 15. ábrán a rezonanciacsúcs eltolódásának a mértékét mutatom be, a RC inkubálási koncentrációjának a függvényében a két kötési protokoll elvégzése után. Jól látható, hogy bármely inkubációs RC koncentrációnál a "peptid módszer" nagyobb vörös irányú eltolódást okoz a spektrumban, mint a "szilánGTA módszer”. A RC PSi-hez történő kötődése egyszerü telítési kinetikával modellezhetö:

$$
\Delta \lambda_{\mathrm{c}}=\Delta \lambda_{\max } \cdot[\mathrm{RC}] /([\mathrm{RC}]+K),
$$

ahol $\Delta \lambda_{\mathrm{c}}, \Delta \lambda_{\max }$ és $K$ a vörös irányú eltolódás adott $\mathrm{RC}$ koncentrációnál, a várt maximális eltolódás és a RC koncentráció $\Delta \lambda_{\max } / 2-n e ́ l$. Az illesztést követően $\Delta \lambda_{\max }=58$ és $38 \pm 8 \mathrm{~nm}$-nek, $\Delta \lambda_{\max } / 2$-nél mért koncentrációk $3 \mu \mathrm{M}$-nak és $2,8 \pm$ 1,5 $\mu$ M-nak adódtak a peptid és a szilán-GTA módszerek esetében. Ezek a paraméterek egyértelműen azt mutatják, hogy a RC bekötődése hatékonyabb a “peptid módszer" esetében, mint amikor az immobilizálást a "szilán-GTA módszerrel" végeztem. 


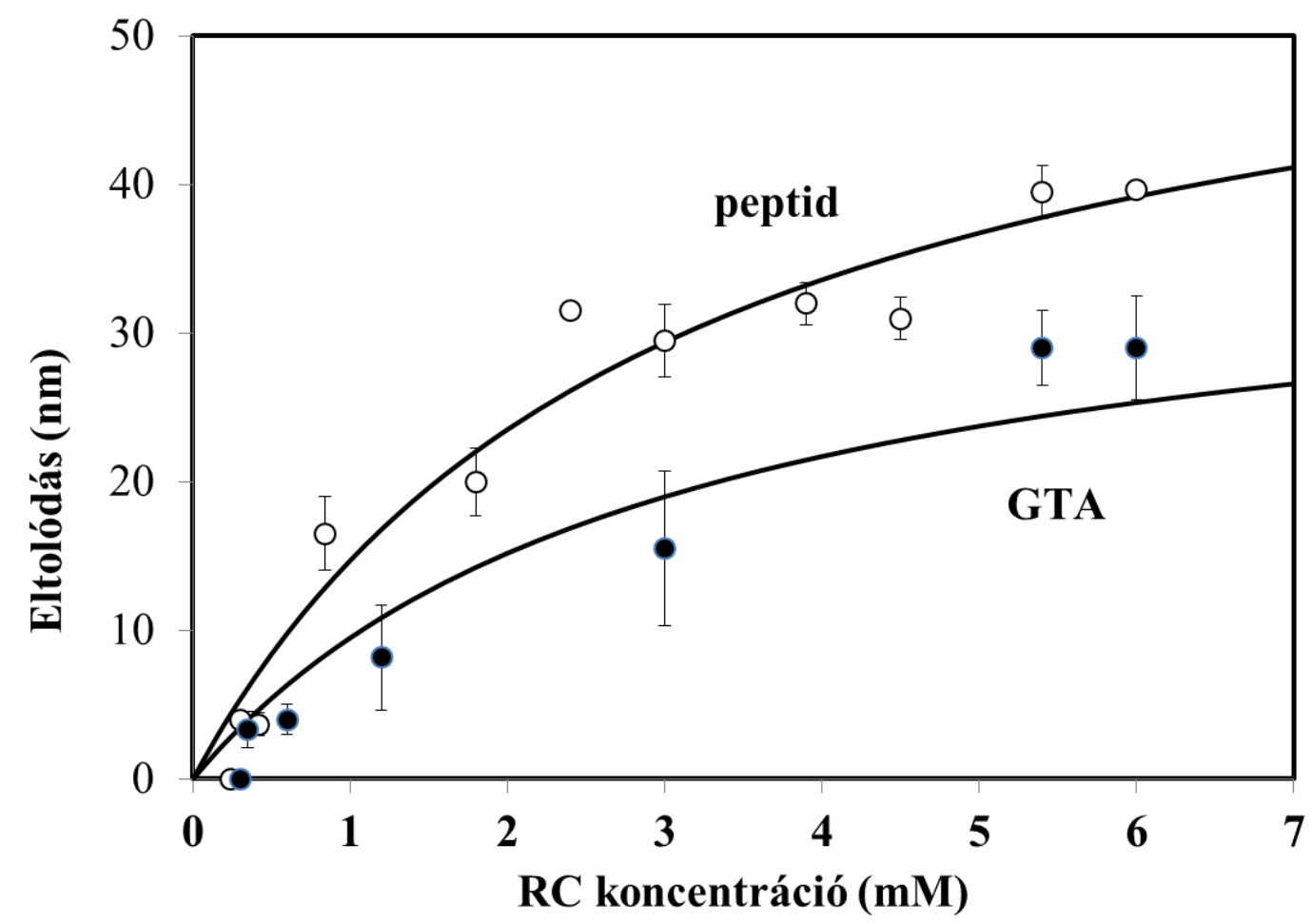

15. ábra A PSi reflexiós csúcs vörös irányú eltolódásának mértéke a RC inkubálási koncentrációjának függvényében a "peptid"és a "szilán-GTA" módszer esetében

A "peptid" módszerrel kapott görbe végig a "szilán-GTA" módszer görbéje felett fut, tehát a vörös irányú eltolódás végig nagyobb a peptid módszerrel ugyanazoknál a RC inkubálási koncentrációknál. A RC kötési affinitása $(\mathrm{K})$ nem különbözik jelentősen a két felszín esetében, így a hatékonyságban megfigyelhető különbség oka lehet a "szilán-GTA módszer" véges számú szabad aldehidcsoportja a "peptid módszer" teljes felületi borítottságával szemben. A "peptid módszer" nagyobb, homogénebb és igen hidrofób felületet biztosíthat a RC megkötődésének. A hidrofobicitás a membránproteinek immobilizálása esetében bizonyítottan meghatározó. A funkció megtartása szempontjából fontos lehet az, hogy a peptidréteg segít megelőzni a megkötött biomolekulák denaturációját (Saab és mtsai., 2010). 


\subsubsection{PSi-hez kötött reakciócentrum fotokémiai/-fizikai aktivitása}

\subsubsection{Töltésszétválasztás egyetlen telítési fénygerjesztést követően}

A reakciócentrum aktivitásának legáltalánosabb vizsgálati módszere az abszorpcióváltozás mérése egyetlen telítési fénygerjesztés után. Hozzáadott elektrondonor nélkül a fehérje komplexben egy pozitív $\left(\mathrm{P}^{+}\right)$és egy negatív $\left(\mathrm{Q}_{\mathrm{B}}{ }^{-}\right)$ töltéspár jön létre a gerjesztés után. A RC csak a töltésrekombinálódást követően gerjeszthető ismét. A PSi felületén immobilizált RC aktivitásának mérése $860 \mathrm{~nm}$ en történt, reflexiós módban. $\mathrm{Ha}$ a kapott jelet RC-oldaton mért abszorpciókinetikai mérésekkel vetjük össze, - feltételezve, hogy megegyezik 860 nm-en az extinkciós koefficiens az oldatbeli értékkel $\left(128 \mathrm{mM}^{-1} \mathrm{~cm}^{-1}\right)-\mathrm{az}$ abszorpcióváltozásból arra lehet következtetni, hogy a RC-oldatból a RC minimum 10\%-a kötődött a PSi felszínhez és maradt aktív (Straley és mtsai., 1973).

Annak ellenére, hogy a reflexiós mód, a pórusokban található kis RC mennyiség, valamint a fényt jelentően szóró porózus felület miatt a jel/zaj viszony nem ideális, kijelenthető, hogy a pórusokba penetrálódott fehérje komplexek fényfelvillanással gerjeszthetőek, tehát megőrizték fotoaktivitásukat mindkét kötési eljárást követően. A "peptid módszerrel" a jel amplitúdója nagyobb volt, mint a "szilán-GTA módszer" esetében, amelynél kb. 30\%-kal kisebb maximális amplitúdó volt megfigyelhetö. A kinetikában is adódtak különbségek. Míg a "peptid módszer" esetében egy komponensü a jel kb. 27 ms-os életidővel, a "szilán-GTA módszer" esetében kétkomponensü kinetikával rendelkezett az abszorpciós görbe, melyek megközelítőleg 50-50\% arányban voltak jelen $13,5 \mathrm{~ms}$ és 240 ms-os életidővel. Az illesztés paramétereit a 4. táblázatban összesítettem. A gyors komponens életideje 10 - 30 ms-os tartományba esik kis eltérésekkel. A RC LDAO detergenses oldatában ez az érték 120 ms körül van (16. ábra). 

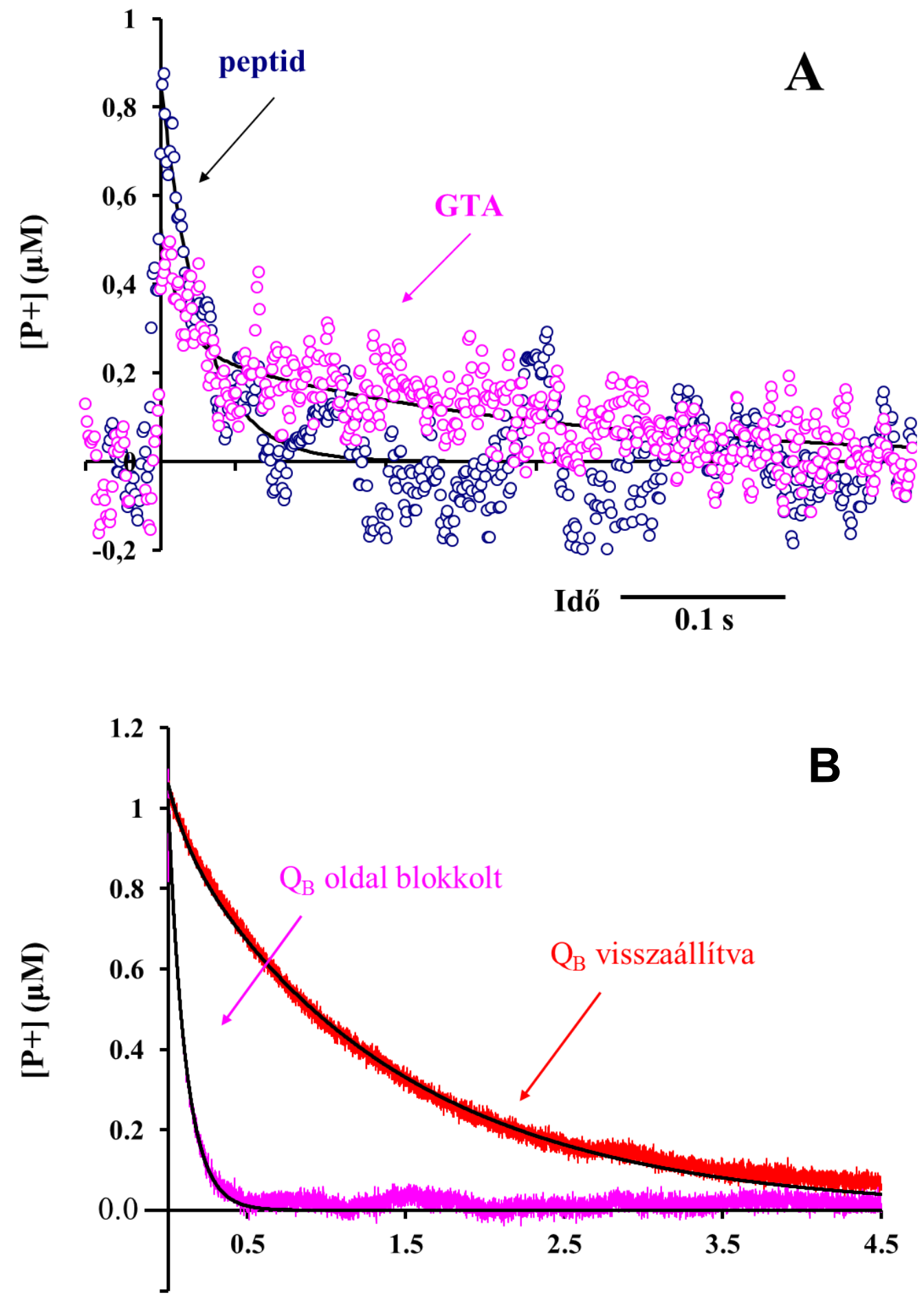

Idő (s)

16. ábra $\mathrm{A} \mathrm{P}^{+}$koncentrációja a PSi-hez kötött (A) és pufferoldatban (10 mM TRIS, 100 $\mathrm{mM} \mathrm{NaCl}, 0,03 \%$ LDAO, pH 8.0) lévő (B) RC esetében 860 nm-en mért flashgerjesztést követő sötét relaxációban. A: A "szilán-GTA" és "peptid módszerrel" kötött RC (az ábrán jelölve). A kihúzott görbéket a 4. táblázatban összesített adatok alapján számoltam. B: A RC akceptor oldalát $100 \mu \mathrm{M} \mathrm{UQ}_{0}$-val helyreállítottam („Q $\mathrm{Q}_{\mathrm{B}}$ helyreállítása”), majd a $\mathrm{Q}_{\mathrm{B}}$ oldalt specifikus inhibítorral (terbutrinnal, „Q $\mathrm{Q}_{\mathrm{B}}$ oldal blokkolt”) gátoltam. 


\begin{tabular}{ccccc}
\hline & $\begin{array}{c}\mathrm{Q}_{\mathrm{A}} \text { minta } \\
\text { oldatban }\end{array}$ & $\begin{array}{c}\mathrm{Q}_{\mathrm{B}} \text { minta } \\
\text { oldatban }\end{array}$ & $\begin{array}{c}\text { "szilán-GTA } \\
\text { módszer" }\end{array}$ & $\begin{array}{c}\text { "peptid } \\
\text { módszer" }\end{array}$ \\
\hline$A_{\text {gyors }}(\%)$ & 100 & 11 & 51 & 100 \\
$\tau_{\text {gyors }}(\mathrm{ms})$ & 110 & 120 & 13,5 & 27,0 \\
$A_{\text {lassú }}(\%)$ & - & 89 & 49 & - \\
$\tau_{\text {lassú }}(\mathrm{ms})$ & - & 1400 & 240 & - \\
\hline
\end{tabular}

4. táblázat: Az abszorpciókinetikai mérések adatainak összesítése. Az adatok a 16. ábrán bemutatott mérés görbeillesztési paraméterei. $A_{\text {gyors }}$ és $A_{\text {lassú }}$ a gyors és lassú komponensek részarányai (százalékban), $\tau_{\mathrm{gyors}}$ és $\tau_{\text {lassú }}$ ezen komponensek időállandói. $\mathrm{Q}_{\mathrm{A}}$ és $\mathrm{Q}_{\mathrm{B}}$ minták RC pufferben (10 mM TRIS, pH 8,0, $100 \mathrm{mM} \mathrm{NaCl,0,03 \%} \mathrm{LDAO).} \mathrm{Q}_{\mathrm{A}}$ mintánál $\mathrm{Q}_{\mathrm{B}}$ oldal terbutrinnal blokkolt, $\mathrm{Q}_{\mathrm{B}}$ mintánál a $\mathrm{Q}_{\mathrm{B}}$ oldalt helyreállítottam. "Szilán-GTA" módszer és "peptid" módszer a PSi-hez két módszerrel kötött RC mintákat jelöli. $\mathrm{r}^{2}$ értékek 0,97, 0,60 és 0,62 oldatban, "szilán-GTA" módszerrel és "peptid" módszerrel sorrendben.

\subsubsection{Folyamatos töltésszétválasztás}

A reakciócentrum müködése során a gerjesztés után keletkezett oxidált primer donort $\left(\mathrm{P}^{+}\right)$in vivo és in vitro körülmények között egyaránt redukálhatjuk a citokróm c-vel, a gerjesztett elektron pedig egy kinontípusú akceptorra kerül. A $\mathrm{RC}$ fotociklusa során folyamatos a töltésszétválasztás, a citokrómok és kinonok folytonosan átadják és elviszik az elektronokat. Ezt a folyamatot jellemezhetjük a citokróm fotooxidációjának megfigyelésével is (Kleinfeld és mtsai., 1984; Osváth és mtsai., 1996). Ebben az esetben exogén citokróm (pl. emlős, vagy élesztőböl kivont citokróm) is betöltheti a RC fotociklusában az elektrondonor szerepét. A citokróm c oxidációját $550 \mathrm{~nm}$-en az abszorpciós sáv fényfelvillanást követő csökkenésével lehet nyomon követni. A kinetika és az abszorpciós sáv változása nagyban függ az oldatban lévő redox komponensek mennyiségétől és arányától.

A 17. ábra a citokróm spektrumának változását mutatja az egyes fényfelvillanásokat követően olyan UQ-t tartalmazó foszfát puffer oldatban mérve, amelyben a RC/PSi lap teljes terjedelmében elmerült a mérés ideje alatt. A bal felső sarokba beszúrt ábrán a citokróm teljesen oxidált és teljesen redukált 
alakjának spektruma látható, az összehasonlíthatóság kedvéért. Kontroll mérésként a citokróm spektrumot RC/PSi lap nélkül is megmértem. Ebben az esetben a spektrum nem mutatott változást a fényfelvillanást követően.

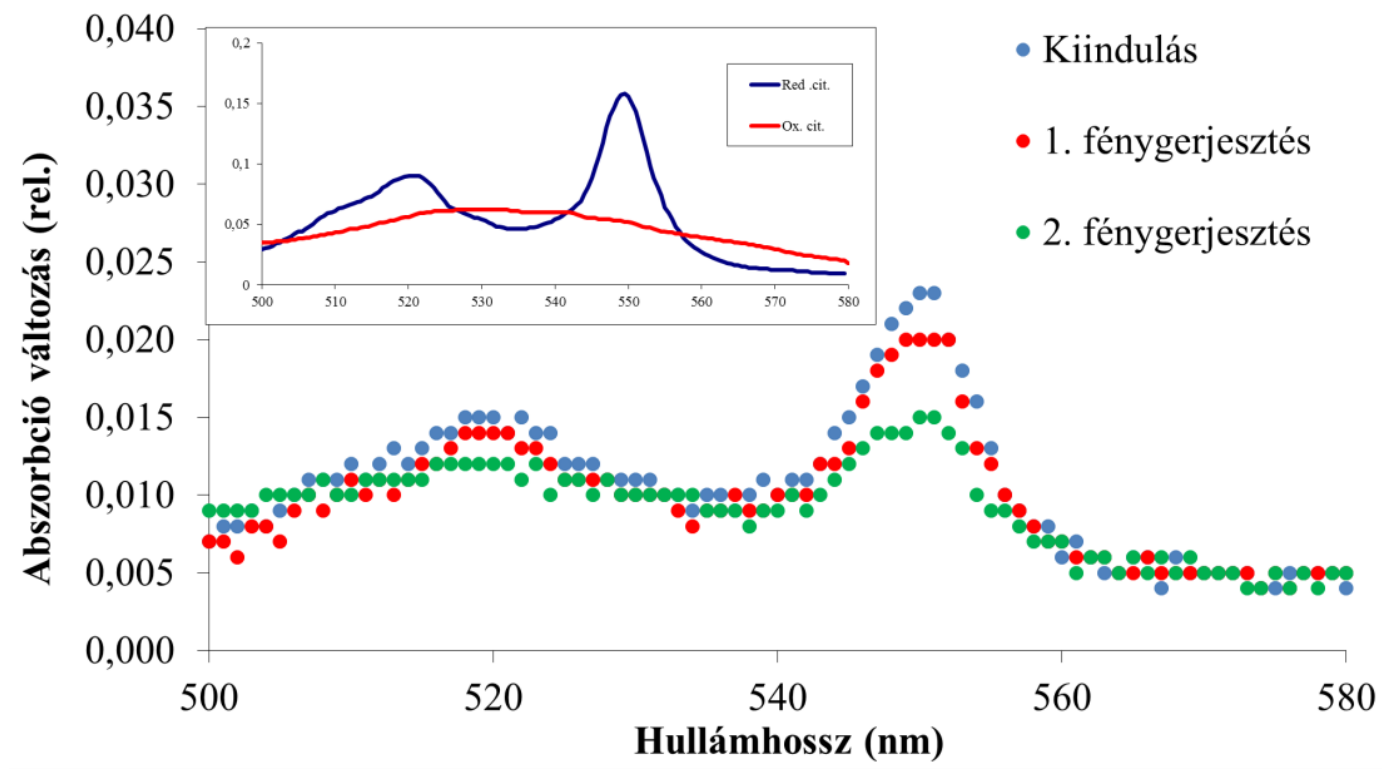

17. ábra A citokróm abszorpciós spektruma a PSi-hez kötött RC fénygerjesztése során, többszöri fényfelvillanások után. A beszúrt ábrán a redukált és az oxidált citokróm spektruma látható.

A citokróm abszorpciós csúcsának egyértelmü csökkenése mérhető volt ismétlődő fénygerjesztéssel is (18. ábra). Ebben az esetben a mérés $550 \mathrm{~nm}$-en történt a kinon és citokróm raktárként szolgáló pufferes folyadékfázisban. A gerjesztő fényimpulzus $(\lambda>720 \mathrm{~nm})$ az oldatban álló $\mathrm{RC} / \mathrm{PSi}$ felületére merőlegesen érkezett, míg az 550 nm-es mérőfény csak a RC/PSi lappal érintkező folyadékfázist keresztezte a lapkával párhuzamosan, azt nem érintve. Az abszorpcióváltozás jelzi a gerjesztett RC fotokémiája miatt létrejövő oxidált citokróm felhalmozódását. A folyamatot a rendszer $\mathrm{UQ}_{0}$ koncentrációja is befolyásolja. Kis kinonkoncentráció esetén a jel amplitúdója kisebb, és minden fényfelvillanást követően megfigyelhető egy nagyobb esés a jelnagyságban. Ez a jelenség a folyadékfázisban lévő redukált kinonok és oxidált citokrómok között létrejövő közvetlen redox reakciók miatt lehet. 


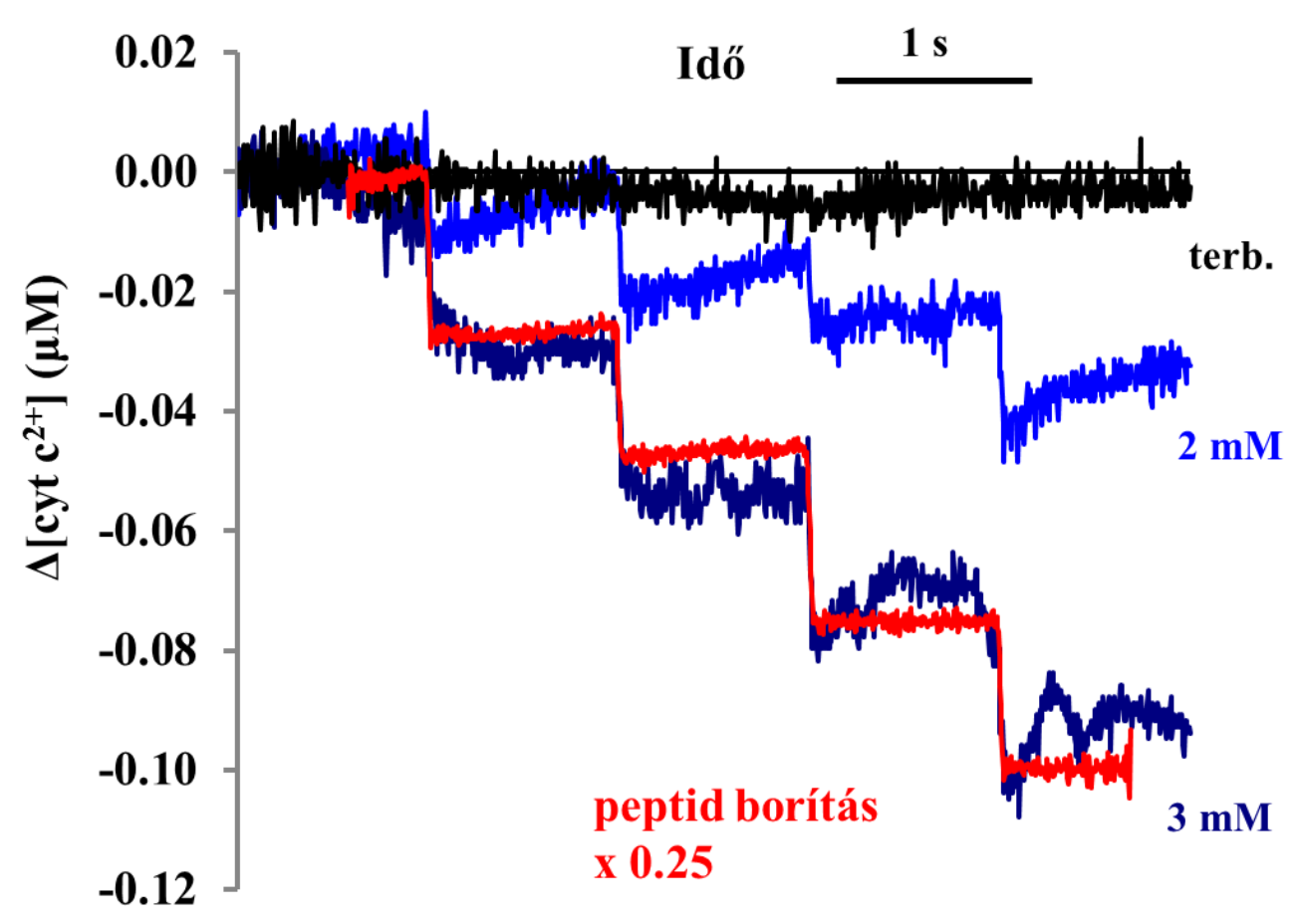

18. ábra A redukált citokróm $\mathrm{c}\left(\mathrm{cyt}^{2+}\right)$ koncentrációjának változása folyadékfázisban, $550 \mathrm{~nm}$-nél, sorozatos telítési fénygerjesztést követően RC/PSi kompozit jelenlétében. A kompozit "szilán-GTA" (kék) és "peptid módszerrel" (piros) lett létrehozva. Az oldat 12 $\mu \mathrm{M}$ lószív citokróm c-t és $2 \mu \mathrm{M}$ majd $3 \mu \mathrm{M} \mathrm{UQ}_{0}$-t és végül terbutrint (fekete színü) is tartalmazott. A gerjesztő fényfelvillanások ismétlődésének sebessége $1 \mathrm{~Hz}$.

A citokróm oxidációja terbutrin hozzáadásával blokkolható volt. A terbutrin az akceptor oldal felöli elektrontranszport inhibítora. A reakció kinetikája egy komplex redox egyensúlyi rendszer eredménye, amely függ a rendelkezésre álló kinon és citokróm készlettől, valamint lehetséges, hogy magától a hordozó PSi-tól is. Ennek az összetett rendszernek a müködését gátolja a terbutrin jelenléte.

Korábban bebizonyosodott, hogy a "peptid módszer" jobb feltételeket biztosít a RC-nak a PSi felületén (a felülethez több fehérje kötődik, és a töltésstabilizálódás mértéke is nagyobb). A citokróm oxidációjának vizsgálata szintén ezt a megfigyelést támasztja alá. Ugyanazon mérési körülmények és koncentrációk mellett a "peptid módszerrel" létrehozott RC/PSi komplex esetében négyszer annyi oxidált citokróm keletkezett a fénygerjesztést követően, mint a "szilán-GTA módszer" esetében. A mérés tehát azt mutatja, hogy miután a RC bekötődik a PSi pórusaiba, a $\mathrm{Q}_{\mathrm{B}}$ oldal hozzáférhető marad az oldat fázisban lévő 
kinon és terbutrin számára is. Fontos, hogy a hordozó felületen rögzített RC redukálható exogén citokróm c által.

\subsection{RC/SWCNT komplex tulajdonságai}

Clayton és munkatársai már 1978-ban kimutatták, hogy csakúgy, mint a szuszpenzióban lévő mintákon, üveglapra szárított RC mintán is lehetséges fotokémiai aktivitást mérni, akár detergenst tartalmazó filmmel együtt is (Clayton és mtsai., 1978). Dorogi és munkatársai bebizonyították, hogy az egyfalú szén nanocsőhöz (SWCNT) fiziszorpcióval (nem kovalens módon, hanem elektrosztatikus kölcsönhatásokkal) kötött reakciócentrum fehérje üveglapra szárítás után is megtartja fotofizikai/-kémiai aktivitását (Dorogi és mtsai., 2006). Az egyetlen telítési fényimpulzus után mért abszorpcióváltozás mind 430, mind 860 nm-nél jellegzetes, kétfázisú kinetikát mutat.

Munkám során célul tüztem ki a RC kémiai kötését funkciós csoporttal rendelkező szén nanocsövekhez. Egyfalú, aminocsoporttal funkcionált szén nanocsövet használtam, amihez glutáraldehid homobifunkcionális keresztkötöszer használatával rögzítettem a fehérje komplexet (19. ábra).

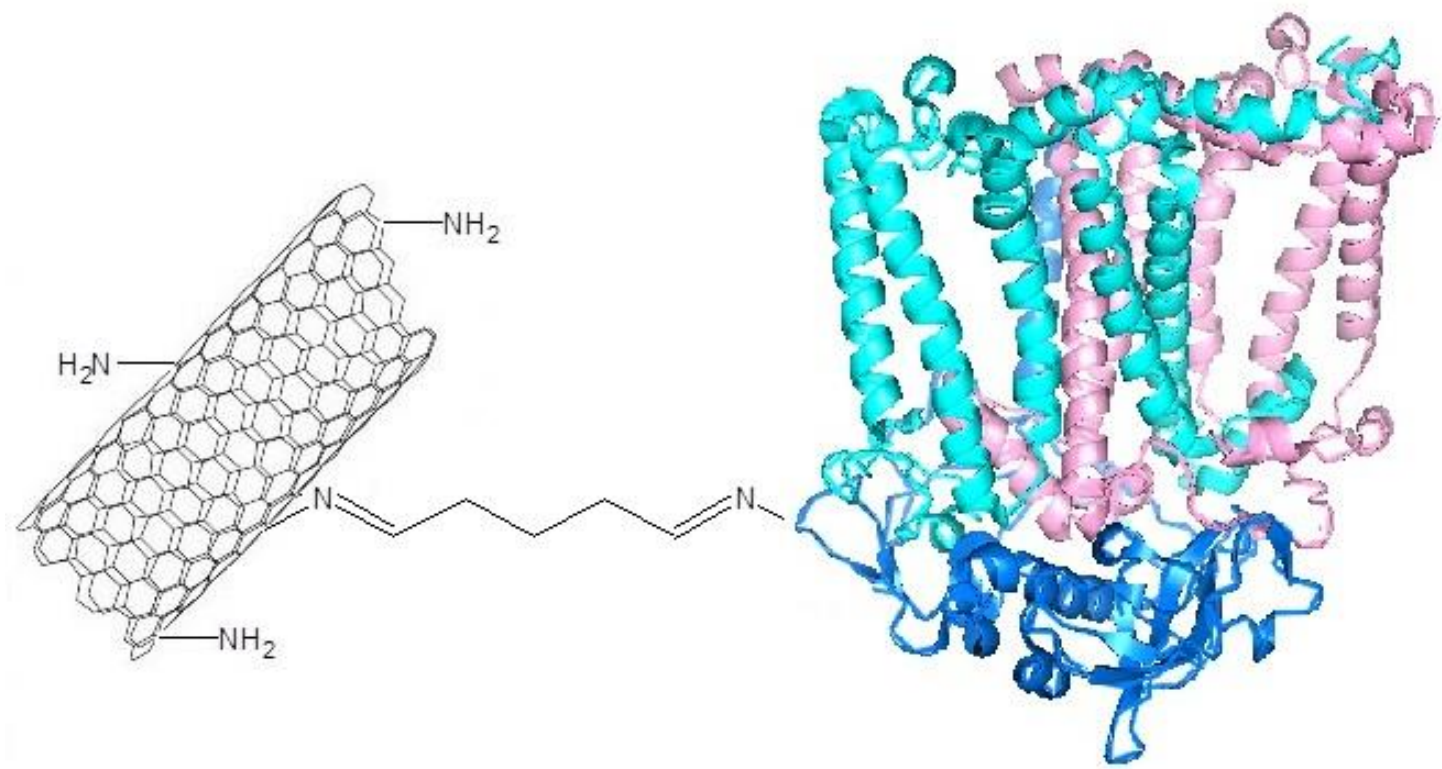

19. ábra Az aminocsoporttal funkcionált SWCNT-hez kötött RC sematikus ábrája. A keresztkötőszer glutáraldehid volt. 


\subsubsection{A RC/SWCNT komplexek morfológiai jellemzése}

A kompozit morfológiai jellemzését, és egyben a $\mathrm{RC}$ rögzítésének hatékonyságát AFM-mel készült felvételekkel ellenőriztem (20. ábra). A RC/SWCNT kompozitról készült AFM felvételek azt mutatják, hogy lehetséges volt a RC-ot az aminocsoporttal funkcionált SWCNT-hez kötni GTA keresztkötő molekula segítségével. A 20. ábrán bemutatott magasságprofil szerint a RC/SWCNT komplex magassága kb. $12 \mathrm{~nm}$. Az egyfalú szén nanocsövek átlagos átmérője 1-2 nm körüli. Dorogi és munkatársai korábbi eredményei szerint a RC átlagos átmérője 9-10 nm (Dorogi és mtsai., 2006). Ebből a két adatból arra lehet következtetni, hogy a SWCNT felületén sikerült egy egyrétegü RC réteget létrehozni, ahol a RC-ok kémiai kötéssel kapcsolódnak a szén nanocsőhöz.

A kémiailag nem, csupán fizikailag kötődött RC-okat többszöri detergenses mosással és centrifugálással távolítottam el a komplexből. A centrifugálást követően a felülúszó spektrumát minden lépés után UNICAM UV4 típusú spektrofotométerrel ellenőriztem mindaddig, amíg már nem tartalmazott RC-ot. A RC közeli infravörös tartományban elhelyezkedő jellegzetes hármas csúcsa a kezdeti centrifugálásokat követően csökkent, majd teljesen eltünt a mosó puffer spektrumából. Ennek az alapos mosási eljárásnak köszönhetően a mintában csak az SWCNT-hez kémiailag kötött RC található, nem maradt a komplexen fizikailag kötött fehérje. 

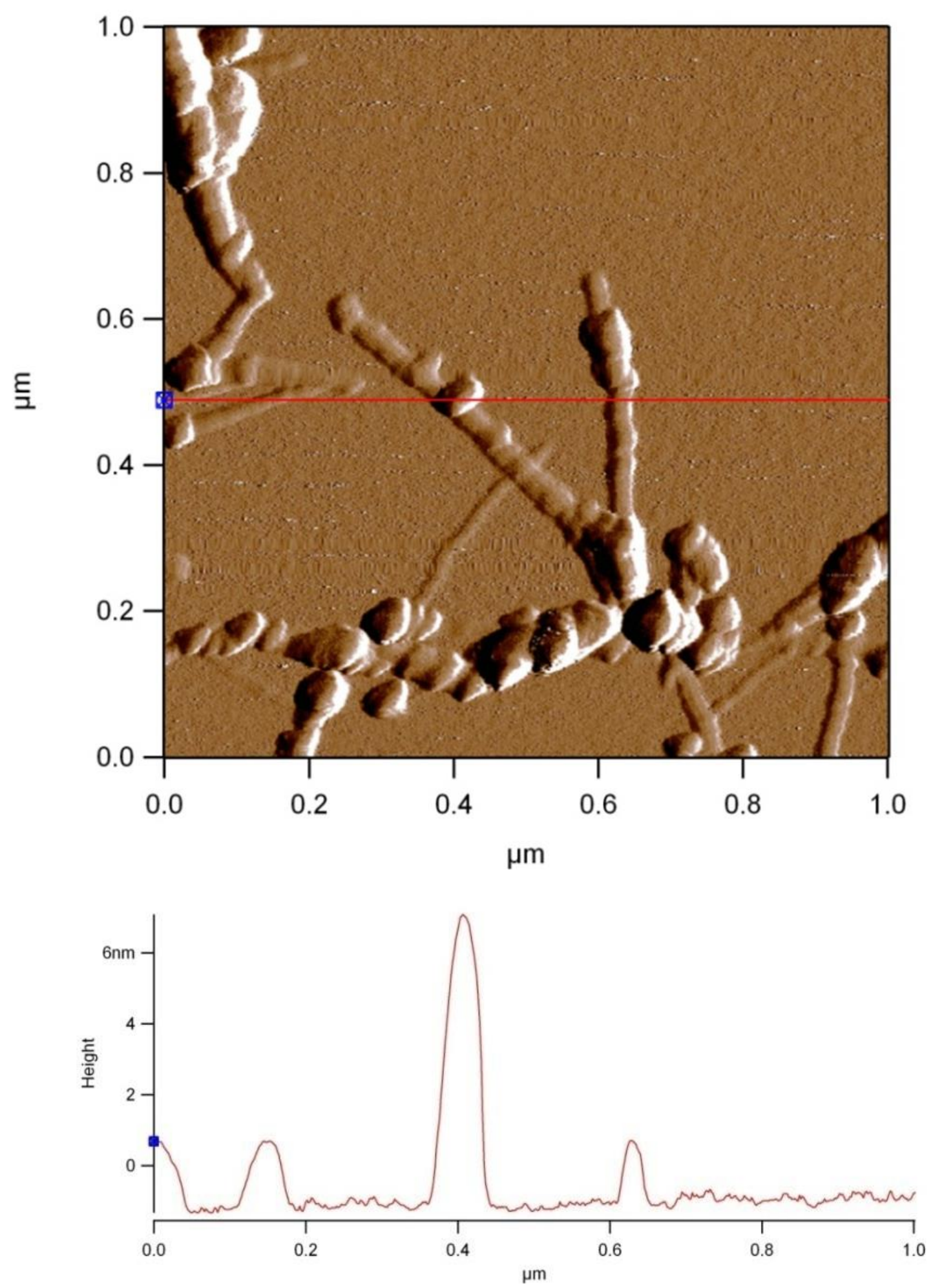

20. ábra A RC/SWCNT komplexről készült AFM-kép (felül), valamint a vonalnak megfelelö magasságprofil (alul) 


\subsubsection{Az egyfalú szén nanocsövön rögzített reakciócentrum aktivitása}

A nanocsőhöz kötött reakciócentrum fotoaktivitását fényindukált abszorpcióváltozás mérésével vizsgáltam. Egyetlen telítési fénygerjesztést követően mértem a $\mathrm{P}$ klorofill dimer elsődleges elektrondonor abszorpciójának változását $430 \mathrm{~nm}$-es hullámhosszon.

A töltésszétválasztás és a rekombináció is több lépésből álló reakciósor. Az abszorpcióváltozás lecsengését vizsgálva két fő komponenst különíthetünk el. A gyors komponens az elsődleges $\left(\mathrm{P}^{+} \mathrm{Q}_{\mathrm{A}}{ }^{-} \rightarrow \mathrm{PQ}\right)$, míg a lassú a másodlagos kinonról történő rekombinációra $\left(\mathrm{P}^{+} \mathrm{Q}_{\mathrm{B}}{ }^{-} \rightarrow \mathrm{PQ}_{\mathrm{B}}\right)$ jelemző. $\mathrm{A} \mathrm{RC}$ egy igen stabil fehérje komplex, sokáig megőrzi az aktivitását, de az abszorpcióváltozás kinetikája a minta életidejével változik. Nem csak a teljes amplitúdóban figyelhetünk meg csökkenést egy bizonyos idő elteltével, de a gyors és lassú komponensek részarányában és életidejében is. Ezért a kompozit abszorpcióváltozásának kinetikáját az eltelt idő függvényében is megvizsgáltam. Az elkészített RC/SWCNT kompozitot üveglapra cseppentettem, $\mathrm{N}$ áram alatt szárítottam, és több héten keresztül azonos körülmények között mértem az abszorpcióváltozás kinetikáját.

A karakterisztikus kétfázisú kinetikák a 21. ábrán láthatóak. A folytonos fekete vonalak a multiexponenciális görbeillesztések eredményeit mutatják, egyszerre láthatjuk a mért és a számított görbéket. A jobb láthatóság kedvéért csak a tendenciát jellemzően mutató adatsort tüntettem fel. 


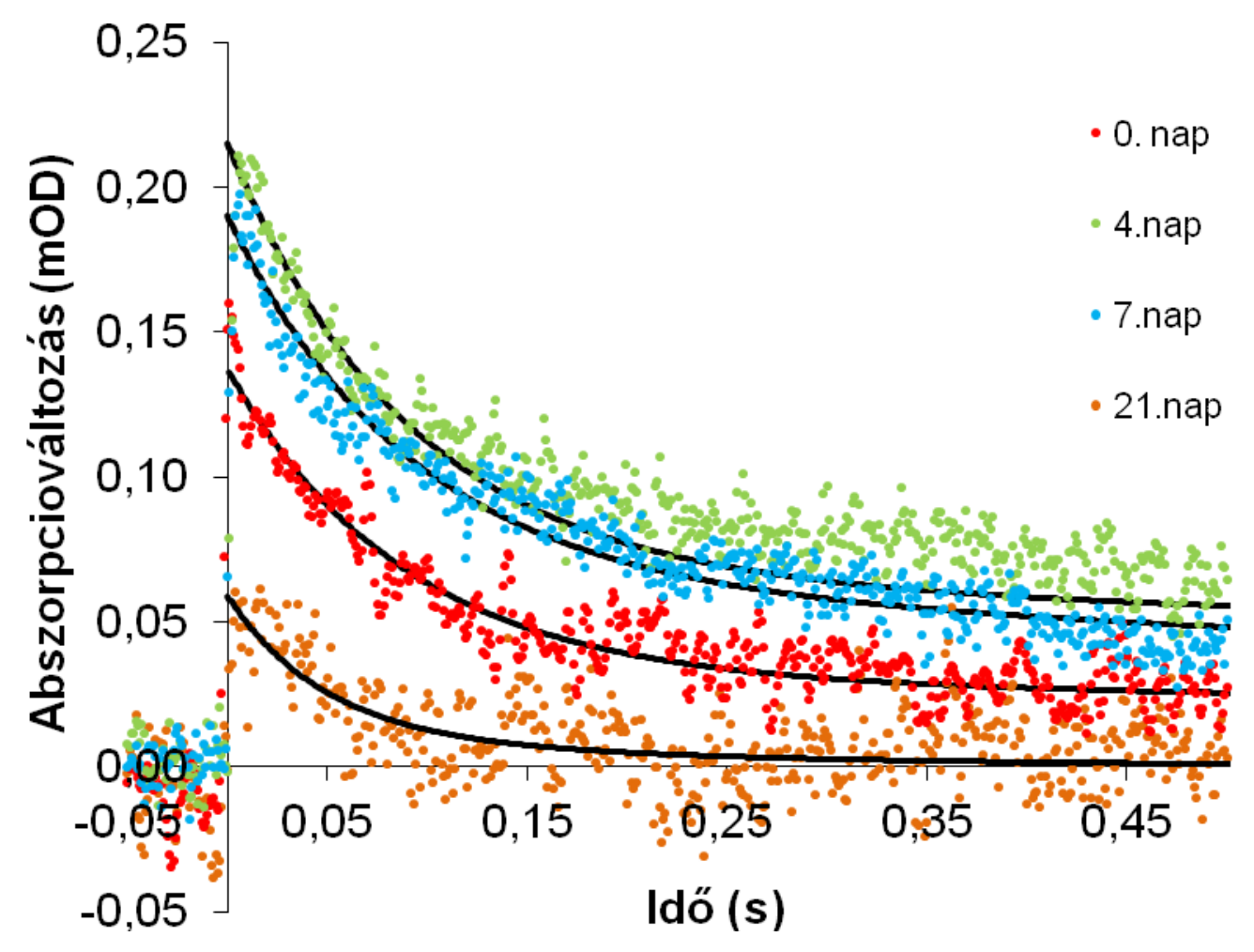

21. ábra A RC/SWCNT komplex abszorpcióváltozása az idő függvényében egyetlen telítési, rövid idejü fényimpulzussal történő gerjesztés után. A RC-ot az amin-funkcionált SWCNT-hez glutáraldehid keresztkötőszerrel rögzítettem. A mérés 430 nm-en történt. A folytonos vonalak a multiexponenciális görbeillesztés eredményét mutatják, a görbéket a 5. táblázatban megadott paraméterek alapján számoltam.

A multiexponenciális görbeillesztésekből származtatott értékeket a 5. táblázatban mutatom be. A 0 . naphoz képest kezdetben növekszik a teljes amplitúdó, majd a harmadik hét végére erösen lecsökken. A lassú komponens részaránya kezdetben a teljes amplitúdó 22\%-a volt, 2860 ms-os élettartammal, míg a gyors komponens 88 ms-os élettartammal bírt. $\mathrm{A} \mathrm{P}^{+} \mathrm{Q}^{-}$töltéspár életideje az inkubációs idővel egyre csökkent, ezzel együtt a részaránya folyamatosan növekedett, így a 10. nap környékén 50\%-a volt a teljes amplitúdónak, az élettartama pedig 1100 ms-ra csökkent. Ennek a csökkenésnek az oka a még aktív, de funkciójukban korlátozott vagy károsodott $\mathrm{Q}_{\mathrm{B}}$ kötőhellyel rendelkező RC-ok lehetnek. A 22\%-os lassú komponens részarány az első hét végére közel 50\%-ra emelkedett, majd a mérési idő végére lecsökkent. A mérés minden esetben $4{ }^{\circ} \mathrm{C}$ os inkubálás után, szobahőmérsékleten történt. 


\begin{tabular}{ccccc}
\hline $\begin{array}{c}\text { Napok } \\
\text { száma }\end{array}$ & $A_{\mathrm{t}}(\mathrm{V})$ & $\tau_{\text {lassú }}\left(\mathrm{Q}_{\mathrm{B}}\right)(\mathrm{ms})$ & $\tau_{\text {gyors }}\left(\mathrm{Q}_{\mathrm{A}}\right)(\mathrm{ms})$ & $A_{\text {lassú }}(\%)$ \\
\hline 0 & 0,136 & 2860 & 88 & 22,0 \\
4 & 0,215 & 2970 & 90 & 30,2 \\
7 & 0,200 & 1800 & 91 & 41,0 \\
21 & 0.060 & 500 & 110 & 18,6 \\
\hline
\end{tabular}

5. táblázat: A RC/SWCNT egyszeri fényimpulzussal való gerjesztése utáni teljes amplitúdó, lassú $\left(\mathrm{Q}_{\mathrm{B}}\right)$, gyors $\left(\mathrm{Q}_{\mathrm{A}}\right)$ komponensek időállandója és a lassú komponens \%-os változása az inkubálási idő függvényében. $A_{\mathrm{t}}$ a $t=0 \mathrm{~s}$ időpontban mért abszorpcióváltozás

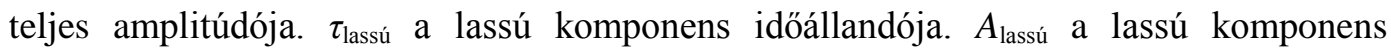
amplitúdója \%-ban. Az adatokat a 21. ábrán bemutatott mérési eredmények alapján számoltam.

Az általam végzett kémiai kötés esetében a lassú komponens életideje és részaránya kezdetben alig változik, egy hét eltelte után mutatkozik jelentősebb csökkenés a lassú komponens részarányában. Dorogi és mtsai (2006) végeztek hasonló stabilitásvizsgálatokat szén nanocsövekhez fizikailag kötött RC-mal. Összehasonlítva az általam készített kémiailag kötött RC lassú komponensének részarányát a fizikailag kötött és LDAO detergenst tartalmazó RC-oldatban mérttel elmondható, hogy a lassú komponens részaránya a leszárítás után minden esetben kb. 30\%-kal csökkent. Minden minta esetén megfigyelhető egy kezdeti növekedés a minta teljes, illetve a lassú komponens amplitúdójában. Ennek oka lehet a szárított minták nedvességtartalmának időbeli változása a szárítást követően is, illetve a relatív detergens tartalom átmeneti változása. Bár a kémiai szorpcióval készült minták is több hétig aktívak maradtak, a fiziszorpcióval kötött RC/SWCNT komplexek voltak a legstabilabbak. Egy hét inkubálási idő után mindössze 70\%-ra csökkent a $\mathrm{P}^{+} \mathrm{Q}^{-}$időállandója (Dorogi és mtsai., 2006), de pár hónap múlva is mérhető a minta fotoaktivitása.

\subsubsection{Szinglet oxigén RC/SWCNT kompozitokban}

A kompozitok stabilitása szempontjából fontosak lehetnek a fénygerjesztés során a fehérje komplexben lejátszódó gyökös mechanizmusok. A fotooxidatív károsodás jelentősen befolyásolhatja a RC élettartamát a komplexekben, ezért ha 
hosszú élettartamú stabil biokompozitot szeretnénk létrehozni, fontos a RC-ot károsító folyamatokat megismerni és a lehetőségekhez mérten minimalizálni.

Az egyik károsító anyag a fotokémiai folyamatok melléktermékeként keletkező szinglet oxigén, melynek roncsoló hatását szemléletesen mutatatja a karotinmentes sejtek érzékenysége a fotodegradációs folyamatokra. Mivel ezekben a sejtekben nem érvényesül a karotin szinglet oxigént kioltó hatása, csak oxigénmentes környezetben növeszthetők fotoszintetikus körülmények között. A karotint is tartalmazó vadtípusú sejtek kiválóan növekednek oxigén jelenétében is.

A szinglet oxigén mennyiségét 1,3-difenilizobenzofurán (DPBF) festék segítségével határoztam meg. Kontroll kísérletként a szinglet oxigén keltésére metilénkék festéket, majd RC-oldatot és végül RC/CNT kompozitokat használtam. A DPBF szinglet oxigénnel reagálva o-dibenzoilbenzénné (DBB) alakul át, amit az abszorpciós spektrum megváltozása követ. Ez a változás irreverzibilis, és a DPBF 420 nm-nél található abszorpciós csúcsának csökkenésével, majd eltünésével jár együtt.

\subsubsection{DPBF-szinglet oxigén reakció kalibrálása}

Mielőtt RC-oldatban mértem volna a fénygerjesztés hatására keletkező szinglet oxigén mennyiségét, egy jól müködő és ismert modell rendszeren alkalmaztam a festéket. Metilénkéket használtam, ami egy vízoldékony, biológiai és kémiai kísérletekben gyakran használt festék, és abszorpciós csúcsa 670 nm-nél található.

DPBF-et tartalmazó (OD 1,6) metilénkék oldatot (OD 1) folytonos vörös fénnyel $(\lambda>620 \mathrm{~nm})$ világítottam meg fél cm-es küvettában, és minden 15 . percben felvettem az oldat teljes abszorpciós spektrumát UNICAM UV-4 kétsugaras spektrofotométerrel. A felvett spektrumok azt mutatták (22. ábra), hogy a megvilágítási idő növekedésével a DPBF 420 nm-nél található csúcsa folyamatosan csökkent, míg a metilénkék 665 nm-es csúcsa nem mutatott változást. A DPBF tehát alkalmazható volt a metilénkék által az oldatban fénygerjesztésre keletkező szinglet oxigén detektálására az adott paraméterek mellett. 


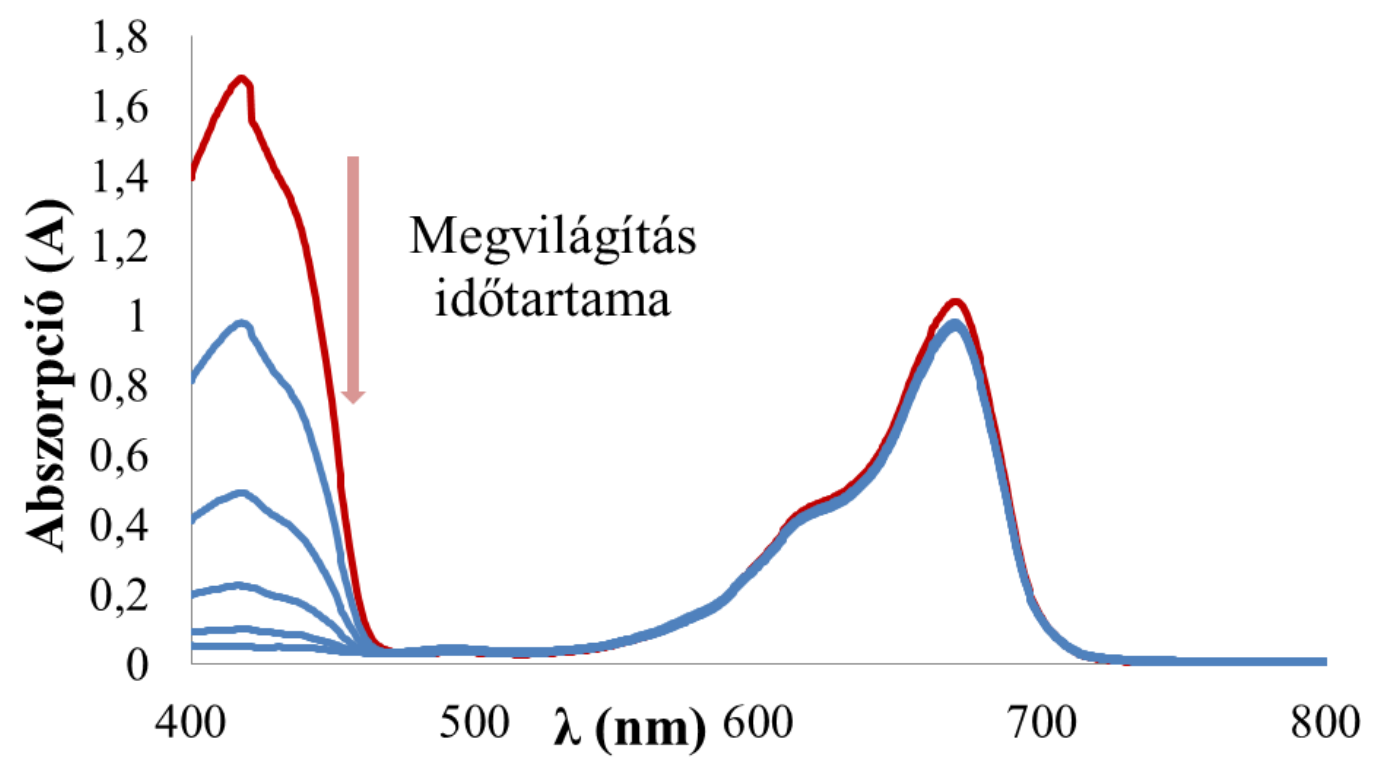

22. ábra A DPBF és metilénkék oldat spektruma folyamatos megvilágítást követően. A nyíl a spektrumok sorrendjét mutatja a megvilágítási idő függvényében. A minta spektrumát minden 15. percben vettem fel.

\subsubsection{A szinglet oxigén egyensúlyi mennyisége szén nanocsövek jelenlétében}

A speciális elektronszerkezetükböl (sp2 hibridállapotú szénatomok kiterjedt $\pi$-elektronrendszere) megjósolható, de kísérleti bizonyítékok is vannak arra, hogy a szén nanocsövek a szinglet oxigénnel kölcsönhatásba léphetnek. Amellett, hogy az egyfalú szén nanocsövek adott körülmények között szinglet oxigént generálhatnak (Chen és Jafvert, 2011), nagyon hatékonyan deaktiválhatják is azt. A deaktiválás mechanizmusa lehet közvetlen energiatranszfer a két komponens között (Chen és Jafvert, 2011), vagy különböző kémiai reakcióutak (Lebedkin és mtsai., 2008). Célom volt, hogy kiderítsem, a szén nanocsövek szerepet játszhatnak-e a hozzájuk kötött RC által generált szinglet oxigén mennyiségének meghatározásában. Ez a kérdés fontos lehet a RC/CNT komplexek stabilitásának meghatározásában. Először megvizsgáltam, hogy a metilénkék által generált szinglet oxigén mennyiségét hogyan befolyásolja a szén nanocső jelenléte, majd hogy hogyan változik a szinglet oxigén koncentrációja a különböző RC/CNT komplexek fotociklusa során. 
Első lépésként a metilénkéket tartalmazó modell rendszeren vizsgáltam a szén nanocső hatását. A DPBF spontán degradációjával három különböző CNT koncentrációval bíró $(0 \mu \mathrm{g} / \mathrm{ml}, 7 \mu \mathrm{g} / \mathrm{ml}, 14 \mu \mathrm{g} / \mathrm{ml}$ CNT) metilénkék oldatot vetettem össze (23. ábra).

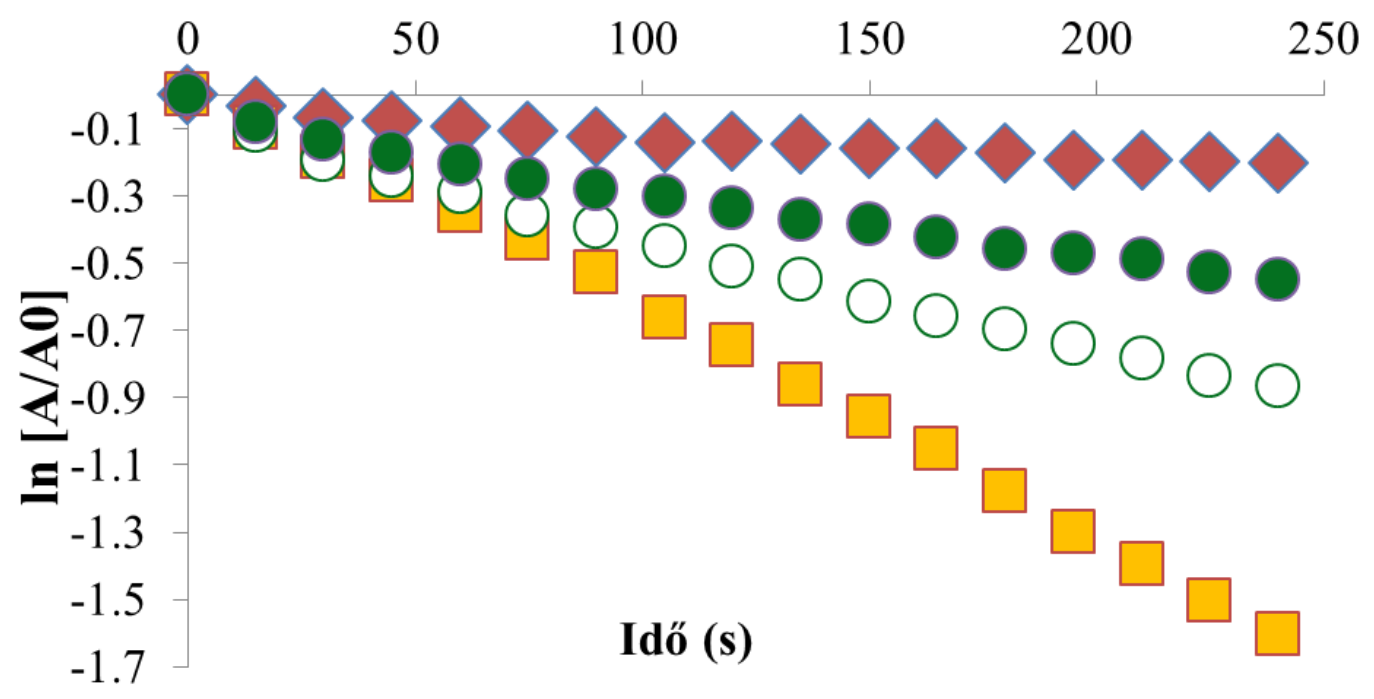

23. ábra A DPBF 420 nm-nél mért abszorpciójának logaritmusa a megvilágítási idő függvényében. Az adott megvilágítási időt követően mért abszorpciót (A) a megvilágítás nélküli kontroll minta abszorpciójához $\left(\mathrm{A}_{0}\right)$ viszonyítottam. - DPBF spontán degradációja, - - DPBF, metilénkék és CNT (14 $\mu \mathrm{g} / \mathrm{ml})$, o - DPBF, metilénkék és CNT (7 $\mu \mathrm{g} / \mathrm{ml})$, $\square-$ DPBF és metilénkék.

A 23. ábrán látható, hogy a CNT-t tartalmazó oldatokban a DPBF 420 nmnél mért abszorpciója a megvilágítási idő függvényében kevésbé csökkent, mint CNT nélkül. Nagyobb CNT koncentráció mellett a DPBF abszorpciója kisebb változást mutatott, ami arra utal, hogy a szuszpenzióban kisebb lett a szinglet oxigén koncentrációja.

A CNT szinglet oxigént kioltó hatása többféle mechanizmussal is magyarázható. Lehetséges, hogy a CNT a szinglet oxigénnel közvetlenül reagál, és közvetlen energiatranszferrel katalizálja az alapállapotú triplet oxigénné alakulását. Másik mechanizmus lehet a közvetlen kémiai (peroxidációs) reakció a szinglet oxigén és a CNT között. Az is lehetséges, hogy a CNT és a metilénkék közötti közvetlen energiatranszfer megelőzi a szinglet oxigén keletkezését, lecsengetve a festék gerjesztett állapotát (Hamon és mtsai., 2007, Lebedkin és mtsai., 2008). 


\subsubsection{A RC fotociklusa során keletkezett szinglet oxigén kimutatása DPBF-fel}

\section{$\underline{\text { A DPBF toxikus hatásának ellenőrzése }}$}

Miután kimutattam, hogy a DPBF alkalmas volt a metilénkékkel szenzibilizált szinglet oxigén kimutatására, RC-oldaton is alkalmaztam ezt a módszert. Első lépésben megvizsgáltam, hogy van-e hatása a DPBF oldatbeli jelenlétének a RC fotoaktivitására, illetve a fényindukált abszorpcióváltozás kinetikájára. A 24. ábrán a RC-oldat 860 nm-en mért fényindukált abszorpcióváltozása látható DPBF jelenlétében és anélkül. A két abszorpciós görbe teljesen egymásra illeszkedik, tehát az általunk használt reagens önmagában nem volt hatással a RC fotoaktivitására.

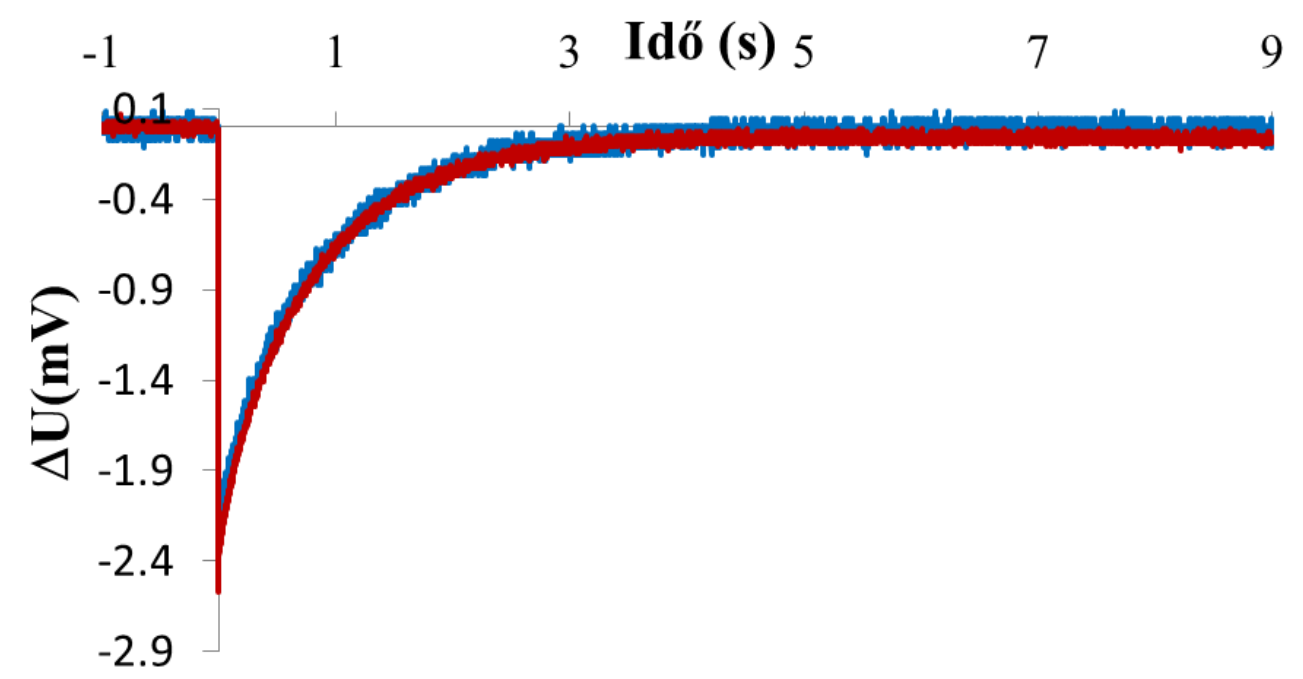

24. ábra A RC-oldat fényindukált abszorpcióváltozása egyszeri telítési fényimpulzussal való gerjesztés után 860 nm-nél DPBF-fel (piros) és DPBF nélkül (kék). A mérés TL pufferben történt.

\section{$\underline{\text { A DPBF micelláris rendszerben való eloszlása }}$}

Mivel a RC detergens micelláris rendszerben van a reakcióelegyben, szükséges megvizsgálni, hogy a detergens jelenléte (a TL pufferben) befolyásoljae a DPBF-szinglet oxigén reakciót. A DPBF-et tartalamzó RC-oldatot molekulaszürö Sephadex G-50 oszlopra helyeztem, így lehetséges volt méret szerint elválasztani az oldat egyes elemeit, és megvizsgálni, hogy mennyire homogén a RC és a DPBF eloszlása a micelláris rendszerben. A 25-ös ábrán 
látható, hogy öt különböző frakciót különítettem el. A beszúrt ábrán összehasonlításul - az elözetesen felvett RC-oldat, DPBF-et tartalmazó RC-oldat és önmagában a DPBF-oldat spektrumait mutatom be. Ezeket összevetve a frakciók spektrumával megállapítható, hogy a 3-as számú, fő frakcióban a DPBF és a RC abszorpciós sávjai együtt jelennek meg, tehát a DPBF képes a RC micellákhoz kötődni. Üres, vagy csak RC-ot, vagy csak DPBF-et tartalmazó micellák gyakorlatilag nincsenek, a minta tehát megfelelőnek látszik.

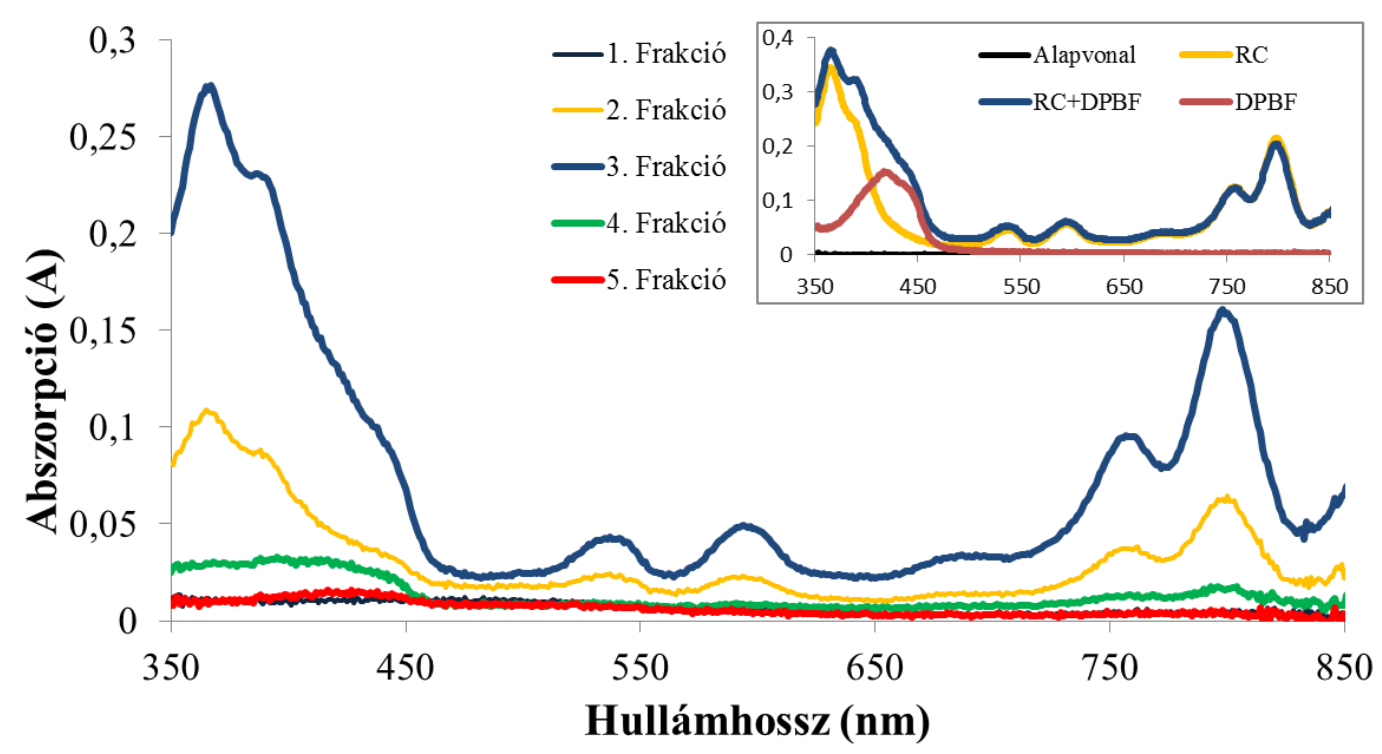

25. ábra RC-DPBF oldat tiszta frakciói Sehadex G-50-es oszlopon való futtatást követően. A beszúrt ábra a RC, a DPBF/RC-keverék és a tiszta DPBF-oldatok spektrumát mutatja.

\section{$\underline{\text { A RC-karotin hatása a szinglet oxigéntermelésre }}$}

Két, különböző Rhodobacter sphaeroides törzsböl izolált fotoszintetikus reakciócentrumot használtam a vizsgálataimhoz. Egyik a vadtípusú, 2.4.1 jelű törzs volt, ezzel hasonlítottam össze a mutáns, karotinoidmentes, R-26 típusú RC szinglet oxigén termelését. A 2.4.1 reakciócentrumban megtalálható karotin szerepe nem csak az, hogy megnöveli a RC abszorpciós keresztmetszetét, hanem fontos szerepe van a reakciócentrum védelmében a fotooxidatív károsodásokkal szemben is. Ebböl adódik, hogy a vadtípusú RC szinglet oxigén termelésének kvantumhatásfoka 0,03 \pm 0,005 (Uchoa és mtsai., 2008), míg a karotinoidmentes R-26 RC esetében ez az érték 0,32 \pm 0,04 (Arellano és mtsai., 2007, Chidsey és mtsai., 1984), így a 2.4.1 típusú reakciócentrum sok esetben stabilabb, mint az R- 
26 típusú mutáns törzs. A két különböző RC-oldat szinglet oxigéntermelésének hatékonyságát megegyező körülmények között vizsgáltam. Azonos koncentrációban adtam hozzájuk DPBF-et, majd vörös $(\lambda>720 \mathrm{~nm})$ fénnyel megvilágítottam, és minden 15. percben megmértem az oldatok spektrumát csakúgy, mint a metilénkékkel szenzibilizált esetben (26. ábra).

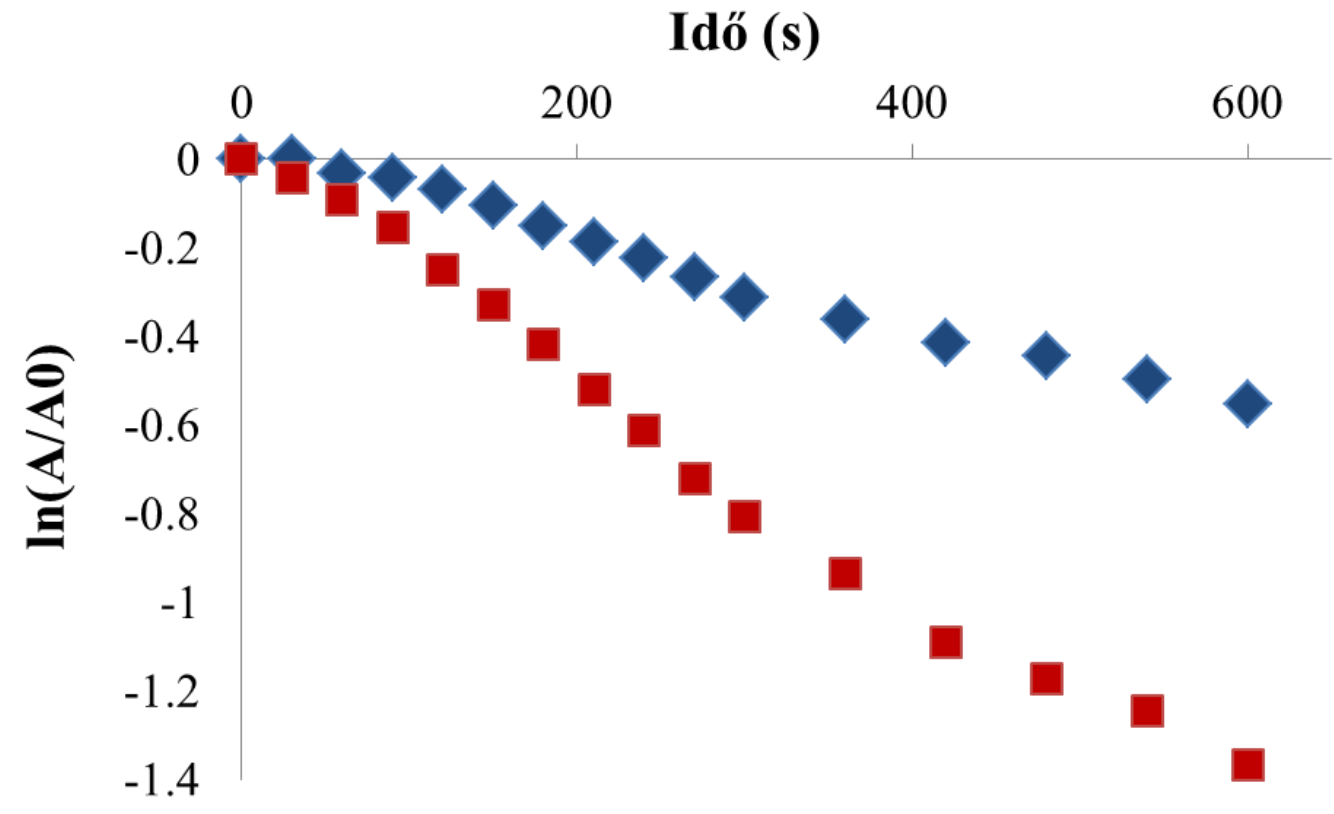

26. ábra A DPBF $420 \mathrm{~nm}$-nél mért abszorpciójának logaritmusa a megvilágítási idő függvényében. Az adott megvilágítási időt követően mért abszorpciót (A) a megvilágítás nélküli kontroll minta abszorpciójához $\left(\mathrm{A}_{0}\right)$ viszonyítottam. Kék görbével (telt rombuszok) a karotinoidot tartalmazó 2.4.1 RC, míg pirossal (telt négyzetek) a karotinoidmentes R-26 RC-oldatok abszorpcióváltozását jelöltem.

A karotint tartalmazó 2.4.1-es RC-oldatban a DPBF abszorpciós csúcs intenzitásának csökkenése az idő függvényében lényegesen kisebb volt, mint a karotinmentes RC törzs esetén. Ez az eredmény arra enged következtetni, hogy a karotin jelenléte valóban meghatározó a fénygerjesztést követő gyökös mechanizmusokban, legalábbis, ami a szinglet oxigén reakcióit illeti, és ez hatással lehet a fehérje komplex funkcionális stabilitására. Mivel a karotin képes lecsengetni a gerjesztés hatására létrejövő triplet állapotokat, kevesebb káros, reaktív szinglet oxigén keletkezik a rendszerben (Uchoa és mtsai., 2008, Arellano és mtsai. 2007, Tandori és mtsai, 2001). 


\subsubsection{Szinglet oxigén a RC/szén nanocső rendszerben}

RC/CNT kompozitok vizsgálata során R-26 típusú RC-ot használtam, mivel a karotinoidot nem tartalmazó RC-ban több szinglet oxigén keletkezik gerjesztést követően, így várhatóan nagyobb különbséget mutathatnak az eltérő összetételű minták. Négy különböző kompozitot készítettem. Az első esetben fizikailag rögzítettem a RC-ot (Dorogi és mtsai., 2006) amin-csoporttal funkcionált egyfalú szén nanocsövekhez. A másik három esetben kémiailag kötöttem a RC-ot egyfalú és többfalú amin-csoporttal funkcionált-, valamint többfalú karboxil-csoporttal funkcionált szén nanocsövekhez. A kompozitokat nanocsövet nem tartalmazó RColdattal, illetve a DPBF spontán degradációjával vetettem össze (27. ábra).

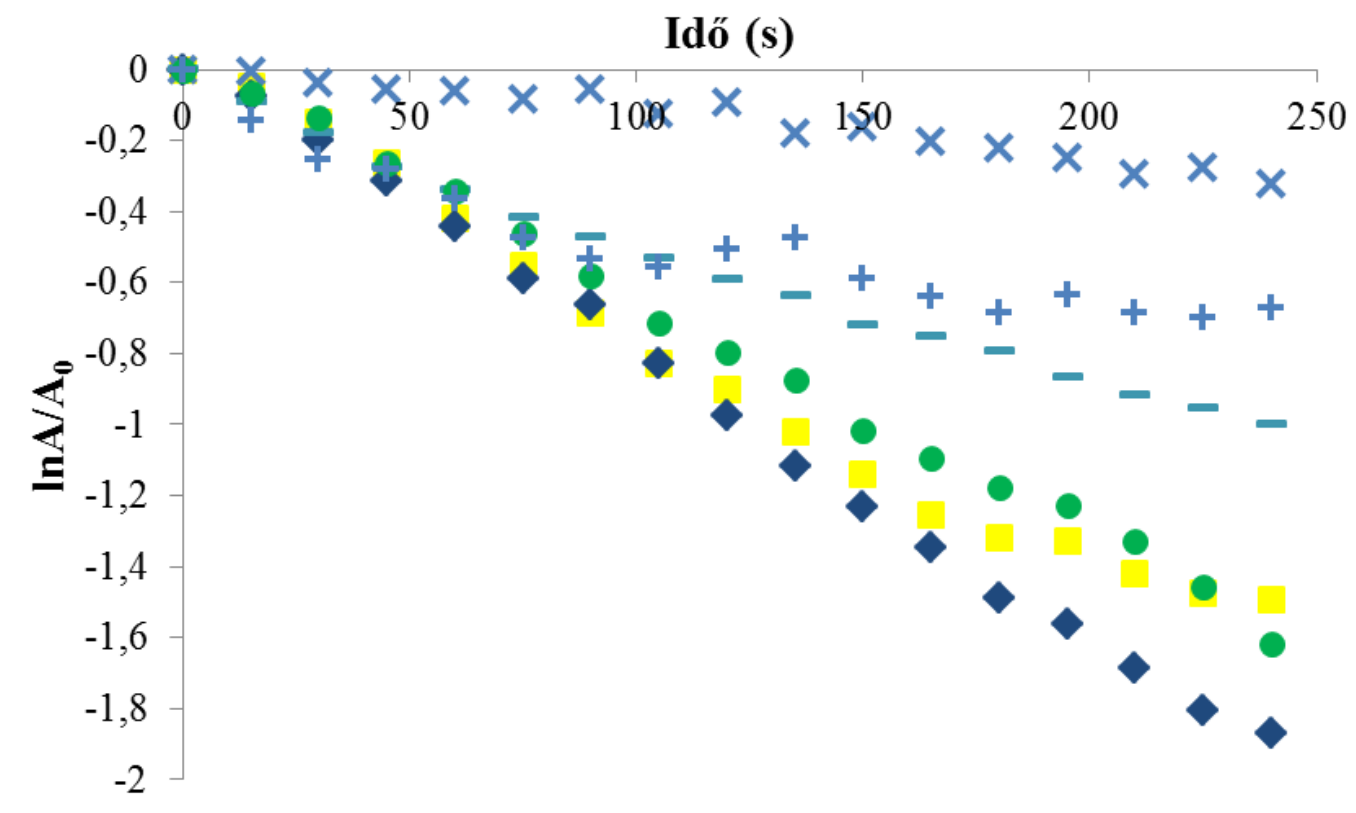

27. ábra A DPBF $420 \mathrm{~nm}$-nél mért abszorpciójának logaritmusa a megvilágítási idő függvényében. Az adott megvilágítási időt követően mért abszorpciót (A) a megvilágítás nélküli kontroll minta abszorpciójához $\left(\mathrm{A}_{0}\right)$ viszonyítottam. (X) RC/SWCNT fizikai kötés, detergens nélkül, (+) RC/CNT fizikai kötés detergenssel, (-) RC-oldat CNT nélkül

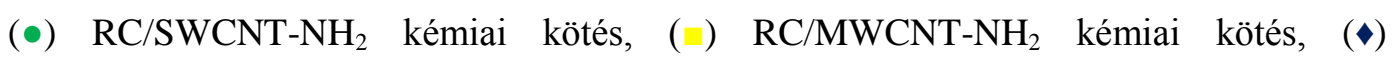
RC/MWCNT-COOH kémiai kötés.

Abban az esetben, ha a RC-ot fizikai szorpcióval kötöttem a szén nanocsövekhez, és az oldat a kritikus micellakoncentráció (cmc) alatti 
koncentrációban tartalmazott detergenst, a DPBF abszorpciójának változása gyakorlatilag megegyezett a DPBF spontán degradációjával (27. ábra). Ezt úgy értelmezhetjük, hogy a DPBF nem tudott a RC közelében jelenlévő szinglet oxigénnel kölcsönhatásba kerülni. Az összes többi, detergenst tartalmazó mintában nagyobb volt a DPBF abszorpcióváltozása, mint a spontán degradáció esetében. Ha a RC-ot fizikai szorpcióval kötöttük a CNT-hez, és a méréseket detergenst tartalmazó TL pufferben végeztük, akkor a CNT hatására kismértékü csökkenés volt látható az abszorpcióváltozásban - kisebb, mint a nanocsövet nem tartalmazó szuszpenzióban -, tehát a modell rendszerhez hasonlóan viselkedett a komplex. Érdekes módon azonban, minden kémiai kötéssel készült RC/CNT komplex esetén jelentős abszorpcióváltozás volt megfigyelhető, mintha a szinglet oxigén mennyisége megnövekedett volna.

A szinglet oxigén reakcióelegybeli koncentrációját több tényező is befolyásolja. A szinglet oxigén egyensúlyi koncentrációját alapvetően a keletkezése irányába mutató szenzitizációs folyamatok és a dezaktivációjának reakciósebességi állandója szabja meg. Alapvető forrása valószínűleg a RC fehérje (28. ábra). A szén nanocsövek is ismert szinglet oxigén szenzitizátorok, ennek azonban esetünkben kicsi a valószínűsége az általunk alkalmazott körülmények miatt (rövid idejü, kis fényintenzású vörös fénnyel történő megvilágítás).

A dezaktivációs folyamatokban egyrészt maguk a RC fehérjék vehetnek részt (autodegradációs folyamatot elszenvedve), de a szén nanocsövek maguk is lehetnek szinglet oxigén dezaktivátorok. A CNT és a szinglet oxigén között közvetlen energiatranszfer is lehet, illetve a szinglet oxigén direkt kémiai reakciókat (peroxidációs folyamatokat) is okozhat.

A szinglet oxigén nagy valószínűséggel minden arra alkalmas komponenssel reagál, szerves vegyületekkel feltétlenül (nem csak a RC fehérjével, hanem pl. a detergenssel vagy TRIS pufferrel, ami az oldatban van), ezért az egyensúlyi koncentrációja az ezekkel való reakcióktól is függ. Mivel a keletkezés helyétől el kell jutnia a reakció helyére, a folyamatot alapvetően befolyásolja a diffúziója, aminek hajtóereje a koncentrációgrádiens. A reakciók hatékonyságát nagyban befolyásolja a diffúziós úthossz.

A szinglet oxigén élettartama vizes közegben néhány $\mu$ s (Merkel és mtsai., 1972, Schweitzer és Schmidt, 2003), amiből Fick II. törvényét felhasználva 
megbescsülhetjük a diffúziós úthosszt. Ha $\tau$ az átlagos élettartam (feltéve, hogy a szinglet oxigén az útjába kerülő anyaggal azonnal reagálva bomlik el), $D$ a diffúziós állandója (kb. $\left.10^{-9} \mathrm{~m}^{2} / \mathrm{s}\right)$, akkor az $x=\sqrt{4 D \tau}$ összefüggést felhasználva kb. 90-120 nm távolságot kapunk. A RC/CNT micelláris rendszer ezen a nagyságrenden belül van, tehát a micellában lévő DPBF mindenképpen képes reakcióba lépni a rendszerben keletkező szinglet oxigénnel.

A szén nanocsövek szerepe nagyon összetett lehet. Függhet a nanocsövek típusától (egyfalú vagy többfalú), kiralitásától, vezetési tulajdonságaitól, illetve attól, hogy funkcionáltak vagy nem funkcionáltak. Ez utóbbival lehet összefüggésben az, hogy az amin-csoporttal funkcionált nanocsöveink esetében a szinglet oxigén mennyisége kevesebbnek adódott, hiszen irodalmi adatok szerint az amin-csoportok jó kioltói lehetnek a szinglet oxigénnek (Bellus, 1978). A lehetséges mechanizmusokat vázolja a 28. ábra.

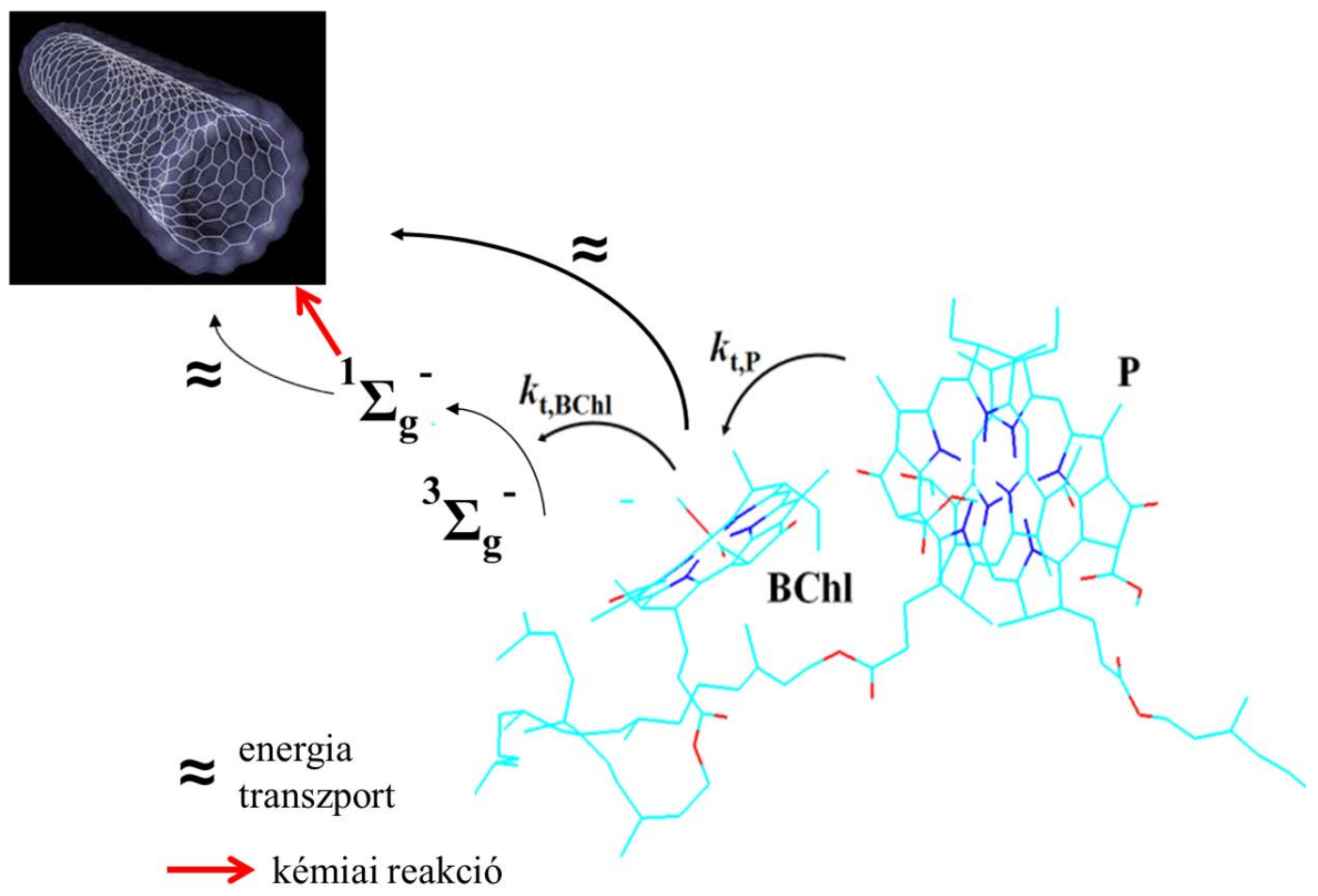

28. ábra A szén nanocsövek lehetséges szerepe a RC által keltett szinglet oxigén dezaktiválási folyamataiban. Jelölések: P: RC primer donor; BChl: bakterioklorofill monomer; $k_{\mathrm{t}, \mathrm{P}}$ és $k_{\mathrm{t}, \mathrm{BChl}}$ : a primer donorról, illetve a bakterioklorofill monomerröl történő triplet energiaátadás sebességi állandója (a jelölés iránya szerint); $3_{\Sigma_{g}^{+}}$: triplet oxigén; $1_{\Sigma_{g}^{-}}$: szinglet oxigén. 


\section{6. Összefoglaló}

Munkám során egész növényi sejtekböl, valamint bakteriális fotoszintetikus reakciócentrumból hoztam létre biokompozitokat. Különböző kötési eljárásokat használtam a biológiai anyagoktól és a hordozótól függően. Az egész sejtes kísérletek során Arabidopsis thaliana növényi sejteket rögzítettem különböző összetételű szilikát mátrixokban, szol-gél módszert alkalmazva. Az így létrejött kompozitokon elektronmikroszkópos felvételekkel vizsgáltam a kötés hatékonyságát és a komplex morfológiai tulajdonságait. Kísérleteim során sikerült megállapítani a prekurzorok optimális arányát az ozmotikus nyomás és a pórusméret figyelembe vételével. A sejtek több héten át megőrizték enzimatikus aktivitásukat, amit oximetriás méréssel ellenőriztem.

Rhodobacter sphaeroides bíborbaktériumból izolált fotoszintetikus reakciócentrumot kétféle hordozóhoz kötöttem. A választott hordozó vezető, illetve félvezető jellegü volt. Elsőként porózus szilíciummal társítottam a RC-ot, amely egy félvezető, speciális réteges struktúrával és fotonikai tulajdonságokkal bíró anyag. Két kötési eljárással immobilizáltam a pórusokban a fehérje komplexet, fizikai és kémiai módszert alkalmazva. A fizikai kötés esetén egy 12 aminosavból álló, a porózus szilícium felszínéhez specifikusan kötődő nagy hidrofobicitással rendelkező peptiddel vontam be a szilíciumlap felszínét. Az így kapott igen hidrofób felszín biztosította a RC erős fiziszorpcióját. A kémiai kötés esetében egy szilanizálási eljárás után szabad amin-csoportok kerültek a PSi felszínére. A RC-ot glutáraldehid amin-célzott homobifunkcionális keresztkötőszerrel rögzítettem. Az így létrejött RC/PSi kompozitokon elektronmikroszkópos felvételekkel, elemanalízissel, valamint Fourier Transzformációs Infravörös Spektroszkópiával határoztam meg a kötési eljárások hatékonyságát. A PSi speciális réteges struktúrájának köszönhetően egy jellegzetes reflexiós spektrummal és ahhoz tartozó módussal bír. A porózus rendszer törésmutatójának és felszíni tulajdonságainak megváltozásával a spektrum eltolódik valamelyik irányba. A reflexiós spektrumra jellemző módus eltolódásának telítési jellegű kinetikájával lehetséges volt a bekötődés leírása.

A reakciócentrum aktivitását az egyszeri telítési fényindukált abszorpcióváltozás kinetikájának mérésével vizsgáltam, speciális reflexiós 
elrendezésben. Mindkét kötéstípussal sikeresen kötődött a RC a PSi-hez, és megőrizte a fotoaktivitását. Összehasonlítva a kétféle eljárást, mindegyik vizsgálati módszer alapján hatékonyabbnak bizonyult a fizikai kötés a kémiai kötésnél, lényegesen több RC kötődött be a PSi pórusrendszerébe a "peptid módszerrel”. A telítődés maximumának a feléhez mindkét esetben kb. $3 \mu \mathrm{M}$ RC koncentráció volt szükséges, de a reflexiós spektrum módusa nagyobb mértékben tolódott el a "peptid módszer" alkalmazásakor $(\Delta \lambda \max =59( \pm 5)$ és $38( \pm 8) \mathrm{nm}$ a peptid és a glutáraldehid alkalmazásakor). A flashfotolízis kísérletek eredményei azt mutatták, hogy a RC a porózus szilíciumhoz történő rögzítés után is aktív maradt. A fénygerjesztést követően keletkezett oxidált klorofill dimer $\left(\mathrm{P}^{+}\right)$ életidejének időbeli lecsengése a peptiddel kezelt mintában egykomponensű ( $\tau=27$ ms), míg a gutáraldehiddel rögzített mintában kétkomponensü $\left(\tau_{1}=14 \mathrm{~ms}, \tau_{2}=230\right.$ $\mathrm{ms}$ ) volt. Sorozatos fénygerjesztés után mérhető volt a citokróm oxidációja, amit terbutrinnal gátolni tudtunk. Ez arra utal, hogy a kötődés után a RC donor és akceptor oldala ezen kofaktorok számára hozzáférhető, és a RC a környezetben levő kofaktorokkal redox kapcsolatban maradt.

A másik hordozó esetében amin-funkcionált egyfalú szén nanocsőhöz rögzítettem a RC-ot kémiailag, glutáraldehid keresztkötőszer alkalmazásával. A létrejött kompozit morfológiai tulajdonságait atomerő mikroszkóppal vizsgáltam meg. A mérések alapján a kötési eljárást követően egyrétegű RC borítás jött létre a nanocső felszínén. A kompozit fotoaktivitását fényindukált abszorpciókinetikai mérésekkel határoztam meg. A RC-ot a kémiai kötést követően is lehetséges volt fénnyel gerjeszteni, és több héten át megőrizte az aktivitását. A fénygerjesztést követően keletkezett oxidált klorofill dimer $\left(\mathrm{P}^{+}\right)$életideje jelentősen megnőtt a komplexekben ( $\tau=1200 \mathrm{~ms}$ és $3100 \mathrm{~ms}$ detergensmicellában és egyfalú szén nanocsőhöz kötve). Az élettartam növekedésének oka valószínüsíthetően az, hogy a szén nanocső környezetében stabilizálódik a RC-on belüli töltéspár. Korábbi vizsgálatainkból arra is következtethetünk, hogy az életidő növekedésének oka az, hogy a RC és a szén nanocső között közvetlen redoxkapcsolat valósul meg.

Fontos, hogy a létrejött biokompozit stabil legyen és hosszútávon megőrizze aktivitását. A RC-ban fénygerjesztést követően triplet állapotok alakulnak ki, ami elösegíti a szinglet oxigén keletkezését. Ezek a mechanizmusok elősegítik a RC aktivitásának csökkenését, lerövidítik a biokompozit élettartamát. Munkám során 
DPBF festékkel mértem a RC/CNT kompozitokban keletkező szinglet oxigén mennyiségét, folytonos megvilágítást követően. Kimutatható volt a karotint tartalmazó 2.4.1 típusú RC és a karotint nem tartalmazó R-26 típusú RC közötti lényeges különbség, ami abból adódik, hogy a karotin képes lecsengetni a bakterioklorofill triplet állapotát. A szén nanocső hatással van a szinglet oxigén oldatbeli egyensúlyi koncentrációjára. Fizikai kötést követően ez a hatás pozitív, a nanocső jelenlétében kevesebb szinglet oxigénnel tudott elreagálni a DPBF. Kémiai kötés esetében nehezebb megmagyarázni a jelenséget, ugyanis a nanocsövet nem tartalmazó oldathoz képest is több szinglet oxigént mutattak a spektrofotometriás mérések. A jelenség megértéséhez, a szinglet oxigén keletkezéséhez és dezaktivációjához vezető folyamatok felderítéséhez további vizsgálatokra van szükség. 


\section{Tudományos megállapítások}

Tudományos eredményeim alapján a következő megállapításokat teszem:

1. Arabidopsis thaliana (lúdfü) egész növényi sejteket sikerrel rögzítettem szilícium alapú hibrid gélben, szol-gél módszerrel. A növényi sejtek a kötési eljárást követően is megörizték aktivitásukat, ahogyan azt a fotoszintetikus oxigénfejlesztő képességük is mutatta. [a,1]

2. Bio-nanokompozitokat készítettem Rhodobacter sphaeroides bíborbaktérium törzsből izolált és tisztított fotoszintetikus reakciócentrum fehérje (RC) vezető és félvezető hordozó anyagok felületén történő rögzítése révén. A RC-okat kémiai és fizikai módszerrel kötöttem a hordozó felületre.

2.1. A fotoszintetikus reakciócentrum fehérjét kémiai úton, glutáraldehid keresztkötő vegyület alkalmazásával egyfalú amin-csoporttal funkcionalizált szén nanocső (SWCNT) felületéhez kötöttem. [a,4]

a) A szerkezeti vizsgálatok (AFM, SEM) azt mutatták, hogy a RC egy rétegben kötődött a szén nanocsőhöz.

b) A flashfotolízis kísérletek alapján az immobilizált RC-ok a kötést követően is megtartották fotoaktivitásukat.

c) Fénygerjesztést követően keletkezett oxidált klorofill dimer $\left(\mathrm{P}^{+}\right)$életideje jelentősen megnőtt a komplexekben ( $\tau=1200 \mathrm{~ms}$ és $3100 \mathrm{~ms}$ detergens micellában, egyfalú szén nanocsőhöz kötve).

d) Az élettartam növekedése magyarázható azzal is, hogy a szén nanocső környezetében a RC-on belüli töltéspár stabilizálódott, de korábbi vizsgálatainkból arra is következtethetünk, hogy a RC és a szén nanocső között közvetlen redoxkapcsolat valósult meg.

2.2. A fotoszintetikus reakciócentrum fehérjét kémiai úton, glutáraldehid keresztkötő vegyület alkalmazásával, valamint specifikus peptid segítségével szilanizált porózus szilícium felületéhez kötöttem. [a,2;3] 
a) A szerkezetvizsgálati és optikai reflexiómérések (SEM, EDX) azt mutatták, hogy a RC mindkét esetben kötődött a porózus szilíciumoz.

b) A kötődés leírható volt a reflexiós spektrumra jellemző módus eltolódásának telítési jellegü kinetikájával, ami azt mutatja, hogy a $\mathrm{RC}$ beépült a porózus szilícium fotonikai rendszerébe.

c) A telítődés maximumának a feléhez mindkét esetben kb. $3 \mu \mathrm{M} R \mathrm{RC}$ koncentráció volt szükséges, de a reflexiós spektrum módusa nagyobb mértékben tolódott el a peptid alkalmazásakor $(\Delta \lambda \max =59( \pm 5)$ és $38( \pm 8) \mathrm{nm}$ a peptid és a glutáraldehid alkalmazásakor).

d) A flashfotolízis kísérletek eredményei azt mutatják, hogy a $\mathrm{RC}$ a porózus szilíciumhoz történő rögzítés után is aktív maradt. A fénygerjesztést követően keletkezett oxidált klorofill dimer $\left(\mathrm{P}^{+}\right)$életidejének időbeli lecsengése a contindel kezelt mintában egykomponensü ( $\tau=27 \mathrm{~ms}$ ), míg a gutáraldehiddel rögzített mintában kétkomponensü ( $\tau_{1}=14 \mathrm{~ms}, \tau_{2}=230 \mathrm{~ms}$ ).

e) A sorozatos fénygerjesztés után mérhető volt a citokróm oxidáció, ami terbutrinnal gátolható volt. Ez arra utal, hogy a kötődés után a RC donor és akceptor oldala ezen kofaktorok számára hozzáférhető, és a RC a környezetében levő kofaktorokkal redoxkapcsolatban maradt. 


\section{Közlemények}

\section{a, A disszertáció alapjául szolgáló közlemények}

1, Meunier, C. F., Rooke, J. C., Hajdu, K., Cutsem, P. V., Alexandre, P. C., Léonard, A., Su, B. L. (2010) Insight into cellular response of plant cells confined within silica-based matrices, Langmuir, 26, 6568-6575. IF: 4,19

2, Hajdu, K., Gergely, Cs., Martin, M., Cloitre, T., Zimányi, L., Tenger, K., Khoroshyy, P., Palestino, G., Agarwal, V., Hernádi, K., Németh, Z., Nagy, L. (2012) Porous silicon/photosynthetic reaction center hybrid nanostructure, Langmuir, 28, 32, 11866-11873. IF: 4,19

3, Hajdu, K., Gergely, Cs., Martin, M., Zimányi, L., Agarwal, V., Palestino, G., Hernádi, K., Németh, Z., Nagy, L. (2012) Light-harvesting bio-nanomaterial using porous silicon and photosynthetic reaction center, Nanoscale Research Letters, 7:400. IF: 2,52

4, Boldog, P., Hajdu, K., Magyar, M., Hideg, É., Hernádi, K., Horváth, E., Magrez, A., Nagy, K., Váró, Gy., Forró, L., Nagy, L. (2013) Carbon nanotubes quench singlet oxygen generated by photosynthetic reaction centers, Physica Status Solidi B, 12, 2539-2543. IF: 1,49

\section{b, Egyéb közlemények}

1, Hajdu, K., Szabó, T., Magyar, M., Bencsik G., Németh, Z., Nagy, K., Magrez, A., Forró, L., Váró, Gy., Hernádi, K., Nagy, L. (2011) Photosynthetic reaction center protein in nano structures, Phys. Status Solidi B, 1-4, / DOI 10.1002/pssb.201100046. IF: 1,49

2, Magyar, M., Hajdu, K., Szabó, T., Hernádi, K.,. Dombi, A., Horváth, E., Forró, L. Nagy, L. (2011) Long term stabilization of reaction center protein photochemistry by carbon nanotubes, Phys. Status Solidi B, 248, No.11, 24542457, DOI 10.1002/pssb.201100051. IF: 1,49

3, Szabó, T., Bencsik, G., Magyar, M., Visy, Cs., Gingl, Z., Nagy, K., Váró, Gy., Hajdu, K., Kozák., G., Nagy, L. (2013) Photosynthetic reaction centre/ITO hybrid nanostructure, Materials Science and Engineering C, 33, 769-773. IF: 2,59 
4, Magyar, M., Hajdu, K., Szabó, T., Endrődi, B., Hernádi, K., Horváth, E., Magrez, A., Forró, L., Visy, Cs., Nagy, L. (2013) Sensing hydrogen peroxide by carbon nanotube/horseradish peroxidase bio-nanocomposite, Phys. Status Solidi B, 12, 2559-2563. IF: 1,49

\section{c, Referált újságban megjelent konferencia absztraktok}

1, Hajdu, K., Gergely, Cs., Martin, M., Zimányi, L., Agarwal, V., Palestino, G., Leza, D. S., Hernádi, K., Németh, Z., Nagy, L. (2011) Porous silicon/photosynthetic reaction center hybrid nanostructure, 2011. Eur Biophys J., 40(1), 35-241, 518.

2, Magyar, M., Hajdu, K., Hernádi, K., Horváth, E., Magrez, A., Nagy, K., Váró, Gy., Forró, L., Nagy, L. (2011) Photosynthetic reaction center/carbon nanotube hybrid nanostructures, 2011 Eur Biophys J., 40 (1), 35-241, 526.

\section{d, Meghívott előadások}

1. Hajdu K. (2011) Photosynthetic reaction center/porous silicon hybrid nanostructure, SH_7_2_20 workshop, Szeged, Magyarország, 2011. szemptember 28-30.

2. Hajdu K. (2012) Porous silicon-photosynthetic reaction centers nanostructure, Photosynthetic proteins for technological applications: biosensors and biochips (PHOTOTECH), Joint Working Groups Meeting, Bukarest, Románia, 2012. május 11-12.

3. Hajdu K. (2013) Detection of singlet oxygen generated by reaction centre, (PHOTOTECH) First Plenary Workshop COST Action TD1102, Antwerpen, Belgium, 2012. június 10-12.

4. Hajdu K. (2013) Detection of singlet oxygen generated by reaction center, SNSF Swiss National Science Foundation Valorization Meeting, Szeged, Magyarország, 2013. június 5-8.

5. Hajdu K. (2013) Nanotube as functional matrix for bacterial photosynthetic reaction centers, Bionanotechnology - Recent Advances, Satellite meeting to the 9th European Biophysics Congress EBSA2013, Sesimbra, Portugália, 2013. július 10-13.

6. Hajdu K., Márquez León J., Cloitre T., Martin M., Agarwal V., Nagy L., Palestino G., Gergely C., Zimányi L. (2013) Optical and electronic properties 
of biomolecule-functionalized porous silicon photonic structures, IMRC International Materials Research Congress, Cancun, Mexikó, 2013. augusztus $11-15$.

7. Ramarkrishnan S. K., Estephan E., Martin M., Cloitre T., Hajdu K., Nagy L., Zimányi L., Palestino G., Agarwal V., Gergely C. (2013) Comprehensive study on porous silicon microcavities' functionalization with peptides for biosensing, IMRC International Materials Research Congress, Cancun, Mexikó, 2013. augusztus 11-15. 


\section{Köszönetnyilvánítás}

Szeretném megköszönni Dr. Nagy László egyetemi docensnek, témavezetőmnek a sok segítséget és tanácsot, amit a dolgozat elkészítése során adott.

Hálás vagyok Dunai Péternének, aki körültekintően elrendezte az adminisztrációval kapcsolatos ügyeimet az egyetemen töltött évek alatt.

Köszönöm Laskayné Tóth Judit laboránsnak és a laboratórium összes dolgozójának, hogy lelkiismeretes és odaadó munkájukkal segítették a mérések elvégzését.

Köszönettel tartozom az alábbi laboratóriumok munkatársainak és vezetőinek, amelyekben szerencsém volt a kutatásaimat elvégezni:

- University of Namur, Laboratory of Inorganic Materials, Namur, Belgium (Prof. Bao Lian Su)

- Université Montpellier 2 és CNRS, Laboratoire Charles Coulomb UMR 5221, Montpellier, Franciaország (Prof. Gergely Csilla)

- École Polytechnique Fédérale de Lausanne, Laboratoire de Physique de la Matiére Complexe, Lausanne, Svájc (Prof Forró László)

- Szegedi Biológiai Kutatóközpont, Biofizikai Intézet, Szeged, Magyarország (Prof. Zimányi László)

- Facultad de Ciencias Químicas, Universidad Autónoma de San Luis Potosí, San Luis Potosí, Mexikó (Prof. Gabriela Palestino)

Fontos megemlíteni, hogy az alább felsorolt projektek nélkül nem jöhetett volna létre az általam elvégzett munka:

- $\quad$ Swiss Contribution (SH/7/2/20)

- Swiss National Scientific Fundation (SNSF IZ73Z0_128037/1)

- CONACYT (Mexikó, No. 801.)

- PHOTOTECH COST Action (TD1102)

- TÁMOP (TÁMOP-4.2.2/B-10/1-2010-0012; TÁMOP-4.2.2.A-11/1/KONV2012-0060)

Továbbá köszönetet szeretnék mondani édesanyámnak, aki mindig mellettem állt, és erején felül segített mindenben. 


\section{Irodalomjegyzék}

Agarwal, V., del Río, J. A. Tailoring the photonic band gap of a porous silicon dielectric mirror, Appl. Phys. Lett. 2003, 82, 1512-1514.

Agarwal, V., del Río, J. A., Zamfirescu, G. M., Kavokin, A., Coquillat, D., Scalbert, D., Vladimirova, M., Gil, B. Photon bloch oscillations in porous silicon optical superlat-tices, Phys. Rev. Lett. 2004, 92, DOI: 10.1103/PhysRevLett.92.097401.

Allen, J. P., Williams, J. C. Photosynthetic reaction centers, FEBS Lett. 1998, 438, $5-9$.

Amat-Guerri, F., Lempe, E., Lissi, E. A., Rodriguez, F. J., Trull, F. R. Water-soluble 1,3-diphenylisobenzofuran derivatives. Synthesis and evaluation as singlet molecular oxygen acceptors for biological systems, J. Photochem. Photobiol. A 1996, 93, 4956.

Anglin, E. J., Schwartz, M. P., Ng, V. P., Perelman, L. A., Sailor, M. J. Engineering the chemistry and nanostructure of porous silicon Fabry-Pérot films for loading and release of a steroid, Langmuir 2004, 20, 11264-11269.

Arellano, J. B., Yousef, Y. A., Melo, T. B., Mohamad, S. B. B., Cogdel, R. J., Naqvi, K. R. Formation and geminate quenching of singlet oxygen in purple bacterial reaction cen-ter, Journal of Photochemistry and Photobiology B: Biology 2007, 87, 105-112.

Aroutiounian, V. M., Martirosyan, K. S., Hovhannisyan, A. S., Soukiassian, P. G. Use of porous silicon for double- and triple-layer antireflection coatings in silicon photovoltaic converters, Journal of Contemporary Physics (Armenian Academy of Sciences) 2008, 43, 72-76. 
Barthlott, W., Neinhuis, C. Purity of the sacred lotus, or escape from contamination in biological surfaces, Planta 1997, 202 (1) 1-8.

Bellus, D. Physical quenchers of singlet molecular oxygen, Adv. Photochem. 1979, 11, 105-205.

Bianco, A., Kostarelos, K., Prato, M. Applications of carbon nanotubes in drug delivery, Current Opinion in Chemical Biology 2005, 9 (6), 574-579.

Blankenship, R. E. Molecular mechanisms of photosynthesis, Blackwell Publishing 2002.

Braun, S., Rappoport, S., Zusman, R., Avnir, D., Ottolenghi, M. Biochemically active sol-gel glasses: the trapping of enzymes, Materials Letters 1990, 10, 1-5.

Campostrini, R., Carturan, G., Caniato, R., Piovan, A., Filippini, R., Innocenti, G., Cappelletti, E. M. J. Immobilization of plant cells in hybrid sol-gel materials, SolGel Sci. Technol. 1996, 7, 87-97.

Campas, M., Carpentier, R., Rouillon, R. Plant tissue-and photosynthesis-based biosensors, Biotechnol. Adv. 2008, 26, 370-378.

Canham, L. T., Reeves, C. L., Newey, J. P., Houlton, M. R., Cox, T. I., Buriak, J. M., Stewart, M. P. Derivatized mesoporous silicon with dramatically improved stability in simulated human blood plasma, Advanced Material 1999, 11(18), 1505-1507.

Carturan, G., Dal Monte, R., Pressi, G., Secondin, S., Verza, P. J. Production of valuable drugs from plant cells immobilized by hybrid sol-gel $\mathrm{SiO}_{2}$, Sol-Gel

Sci. Technol. 1998, 13, 273-276.

Chen, C. Y., Jafvert, C., T. The role of surface functionalization in the solar lightinduced production of reactive oxygen species by single-walled carbon nanotubes in water, Carbon 2011, 49, 5099-5106. 
Chidsey, C. E. D., Kirmaier, C., Holten, D., Boxer, S.G. Magnetic-field dependence of radical-pair decay kinetics and molecular triplet quantum yield in quinone-depleted reaction centers, Biochim. Biophys. Acta 1984, 766, 424-437.

Chin, V., Collins, B. E., Sailor, M. J., Bhatia, S. N. Compatibility of primary hepatocytes with oxidized nanoporous silicon, Adv. Mater. 2001, 13(24), 18771880.

Ciaccafava, A., De Poulpiquet, A., Techer, V., Giudici-Orticoni, M. T., Tingry, S., Innocent, C., Lojou, E. An innovative powerful and mediatorless $\mathrm{H}_{2} / \mathrm{O}_{2}$ biofuel cell based on an outstanding bioanode, Electrochemistry Communications 2012, $23,25-28$.

Collins, B. E., Dancil, K. P., Abbi, G., Sailor, M. J. Determining protein size using an electrochemically machined pore gradient in silicon, Adv. Funct. Mater. 2002, 12, 187-191.

Collins, P. G., Arnold, M. S., Avouris, P. Engineering carbon nanotubes and nanotube circuits using electrical breakdown, Science 2001, 292, 5517, 706-709.

Cunin, F., Schmedake, T. A., Link, J. R., Koh, J., Bhatia, S. N., Sailor, M. J. Biomolecular screening with encoded porous silicon photonic crystals, Nature Materials 2002, 1(1), 39-41.

De Stefano, L., Rotiroti, I., Rendina, I., Moretti, L., Scognamiglio, V., Rossi, M., D'Auria, S. Porous silicon-based optical microsensor for the detection of 1glutamine, Biosensor \& Biolectronics, 2006, 21, 1664-1667.

deWinter, A., Boxer, S. The Mechanism of triplet energy transfer from the special pair to the carotenoid in bacterial photosynthetic reaction centers, J. Phys. Chem. B 1999, 103, 8786-8789.

Dorogi, M., Bálint, Z., Mikó, C., Vileno, B., Milas, M., Hernádi, K., Forró, L., 
Váró, G., Nagy, L. Stabilization effect of single walled carbon nanotubes on the functioning of photosynthetic reaction centers, J. Phys. Chem. B. 2006, 110, 21473-21479.

Estephan, E., Saab, M.-B., Agarwal, V., Cuisinier, F. J. G., Larroque, C., Gergely, C. Peptides for the biofunctionalization of silicon for use in optical sensing with porous silicon microcavities, Adv. Funct. Mater. 2011, 21, 2003-2011.

Estevez, J. O., Arriaga, J., Méndez Blas, A., Agarwal, V. Enlargement of omnidirectional photonic bandgap in porous silicon dielectric mirrors with a Gaussian profile refractive index, Appl. Phys. Lett. 2009, 94, DOI: 10.1063/1.3081113.

Fukushima, Y., Inagaki, S. Nano-scale structure control of mesoporous silica, Mater. Sci. Eng. A 1996, 217/218, 116-118.

Gooding, J. J., Jingquan, R. W., Yang, W., Losic, D., Orbons, D., Mearns, F. J., Shapter, J. G., Hibbert, D. B. Protein electrochemistry using aligned carbon nanotube arrays, Journal of Am. Chem. Soc. 2003, 125 (30), 9006-9007.

Guinan, T., Godefroy, C., Lautrédou, N., Pace, S., Milhiet, P. E., Voelcker, N., Cunin, F. Interaction of antibiotics with lipid vesicles on thin film porous silicon using reflectance interferometric fourier transform spectroscopy, Langmuir 2013, 29(32), 10279-10286.

Guiseppi-Elie1, A., Lei, C., Baughman, R. H. Direct electron transfer of glucose oxidase on carbon nanotubes, Nanotechnology 2002, 13, 559-564.

Hajdu, K., Szabó, T., Magyar, M., Bencsik, G., Németh, Z, Nagy, K., Forró, L., Váró, Gy., Hernádi, K., Nagy, L. Photosynthetic Reaction Center Protein in Nanostructures, Phys. Status Solidi B 2011, 248, 2700-2703. 
Hamon, M. A., Stensaas, K. L., Sugar, M. A., Tumminello, K. C., Allred, A. K. Reacting soluble single-walled carbon nanotubes with singlet oxygen, Chem. Phys. Lett. 2007, 447, 1-4.

Hurt, R. H., Monthioux, M., Kane, A. Toxicology of carbon nanomaterials: Status, trends, and perspectives on the special issue, Carbon 2006, 44(6), 10281033.

Iijima, S. Helical microtubules of graphitic carbon, Nature 1991, 354, 56.

Iijima, S., Ichihashi, T. Single-shell carbon nanotubes of 1-nm diameter, Nature 1993, 363, 603-605.

Kilian, K. A., Böcking, T., Ilyas, S., Gaus, K., Jessup, W., Gal, M., Gooding, J. J. Forming antifouling organic multilayers on porous silicon rugate filters towards in vivolex vivo biophotonic devices, Adv. Funct. Mater. 2007, 17, 2884-2890.

Kim, J., Song, K., Lee, J., Yu, I. Evaluation of biocompatible dispersants for carbon nanotube toxicity tests, Arch Toxicol 2011, 85(12), 1499-1508.

Kleinfeld, D.; Okaamura, M. Y.; Feher, G. Electron transfer in reaction centers of Rhosopseudomonas Sphaeroides. I. Determination of the charge recombination pathway of $\mathrm{D}^{+} \mathrm{Q}_{A} \mathrm{Q}_{B}{ }^{-}$and free energy and kinetic relations between $\mathrm{Q}_{\mathrm{A}}{ }^{-} \mathrm{Q}_{\mathrm{B}}$ and $\mathrm{Q}_{\mathrm{A}} \mathrm{Q}_{\mathrm{B}}{ }^{-}$, Biochem. Biophys. Acta 1984, 766, 126-140.

Kroto, H. W., Heath, J. R., O'Brien, S. C., Curl, R. F., Smalley, R. E. C60: Buckminsterfullerene, Nature 1985, 318, 162-163.

Lakatos, M., Groma, G. I., Ganea, C., Lanyi, J. K., Váró, G. Characterization of the azide-dependent bacteriorhodopsin-like photocycle of Salinarum Halorhodopsin, Biophysical Journal 2002, 82, 4, 1687-1695.

Lebedev, N., Trammell, S. A., Tsoi, A., Spano, A., Kim, J. H., Xu, K., Twigg, M. E., Schnur, J. M. Increasing efficiency of photoelectronic conversion by 
encapsulation of photosynthetic reaction center proteins in arrayed carbon nanotube electrode, Langmuir 2008, 24, 8871-8876.

Lebedkin, S., Kareev, I., Hennrich, F., Kappes, M. M. Efficient quenching of singlet oxygen via energy transfer to semiconducting single-walled carbon nanotubes, J. Phys. Chem. C 2008, 112, 16236-16239.

Liu, X., Vinson, D., Abt, D., Hurt, R. H., Rand, D. M. Environ Differential toxicity of carbon nanomaterials in Drosophila: larval dietary uptake is benign, but adult exposure causes locomotor impairment and mortality, Sci Technol. 2009, 43(16), 6357-6363.

Lu, Y., Xu, Y., Liu, B., Kong, J. Photosynthetic reaction center functionalized nano-composite films: Effective strategies for probing and exploiting the photoinduced electron transfer of photosensitive membrane protein, Biosens. Bioelectron. 2007, 22, 1173-1185.

Lu, Y., Yuan, M., Liu, Y., Tu, B., Xu, C., Liu, B., Zhao, D., Kong, J. Photoelectric performance of bacteria photosynthetic proteins entrapped on tailored mesoporous WO3-TiO2 films, Langmuir 2005, 21(9), 4071-4076.

Kleinfeld, D., Okaamura, M. Y., Feher, G. Electron transfer in reaction centers of Rhosopseudomonas sphaeroides. 1. determination of the charge recombination pathway of $\mathrm{D}^{+} \mathrm{QAQB}$ - and free energy and kinetic relations between $\mathrm{Q}_{\mathrm{A}}-\mathrm{Q}_{\mathrm{B}}$ and $\mathrm{Q}_{\mathrm{A}} \mathrm{Q}_{\mathrm{B}}{ }^{-}$, Biochem. Biophys. Acta 1984, 766, 126-140.

Magrez, A., Kasas, S., Salicio, V., Pasquier, N., Seo, J. W., Celio, M., Catsicas, S., Schwaller, B., Forró, L. Cellular toxicity of carbon-based nanomaterials, Nano Letters 2006, 6 (6), 1121-1125.

Magyar, M., Hajdu, K., Szabó, T., Endrődi, B., Hernádi, K., Horváth, E., Magrez, A., Forró, L., Visy, Cs., Nagy, L. Sensing hydrogen peroxide by carbon nanotube/horse radish peroxidase bio-nanocomposite, Phys. Status Solidi B 2013, 250 (12), 2559-2563. 
Martin, M., Palestino, G., Cloitre, T., Agarwal, V., Zimanyi, L., Gergely, C. Three-dimensional spatial resolution of the nonlinear photoemission from biofunctionalized porous silicon microcavity, Appl. Phys. Lett. 2009, 94, DOI: 10.1063/1.3148698.

Mayne, A. H., Bayliss, S. C. P., Tobin, P. M., Buckberry, L. D. Biologically interfaced porous silicon devices, Phys. Stat. Sol. 2000, 182, 505-513.

Merkel, P. B., Nilsson, R., Kearns, D. R. Deuterium effects on singlet oxygen lifetimes in solutions. New test of singlet oxygen reactions, J Am Chem Soc. 1972, 94, 1030-1031.

Meunier, C. F., Cutsem, P. V., Kwon Y. U., Su B. L. Thylakoids entrapped within porous silica gel: towards living matter able to convert energy, J. Mater. Chem. 2009, 19, 1535-1542.

Meunier, C. F., Dandoy, P., Su, B. L. Encapsulation of cells within silica matrixes: Towards a new advance in the conception of living hybrid materials, Journal of Colloid and Interface Sicence 2010, 342, 2, 211-224.

Mitchel, P. Chemiosmotic coupling in energy transduction: A logical development of biochemical knowledge, Journal of Bioenergetics 1972, 3, (1): 524.

Murashige, T., Skoog, T. A revised medium for rapid growth and bio assays with tobacco tissue cultures, Physiol. Plant 1962, 15. 473-497.

Nagy, L., Milano, F., Dorogi, M., Trotta, M., Laczkó, G., Szebényi, K., Váró, Gy., Agostiano, A. and Maróti, P. Protein/lipid interaction in bacterial photosynthetic reaction center: The role of phosphatidylcholine and phosphatidylglycerol in charge stabilization, Biochemistry, 2004, 43, 12913-12923. 
Nagy, L., Hajdu, K., Fisher, B., Hernádi, K., Nagy, K., Vincze J. Photosynthetic Reaction Centres - from Basic research to application possibilities, Notulae Scientia Biologica 2010, 2(2), 07-13.

Nagy, L., Puskás, Á., Tandori, J., Droppa, M., Horváth, G. Effect of DCMU on photosynthetic purple bacteria, Photosynthetica 1991, 25, 167-171.

Nassif, N., Bouvet, O., Rager, M. N., Roux, C., Coradin, T., Livage, J. Living bacteria in silica gels, Nature Materials 2002, 1, 42-44.

Nelson, A., Cox, D., Lehninger, M. Principles of Biochemistry W H Freeman \& Co. 2009.

Noji, T., Kamidaki, C., Kawakami, K., Shen, J. R., Kajino, T., Fukushima, Y., Sekitoh, T., Itoh, S. Photosynthetic oxygen evolution in mesoporous silica material: Adsorption of photosystem II reaction center complex into $23 \mathrm{~nm}$ nanopores in SBA, Langmuir 2011, 27, 705-713.

Oda, I., Hirata, K., Watanabe, S., Shibata, Y., Kajino, T., Fukushima, Y., Iwai, S., Itoh, S. Function of membrane protein in silica nanopores: Incorporation of photosynthetic light-harvesting protein LH2 into FSM, J. Phys. Chem. B 2006, $110,1114-1120$.

Oda, I., Iwaki, M., Fujita, D., Tsutsui, Y., Ishizaka, S., Dewa, M., Nango, M., Kajino, T., Fukushima, Y., Itoh, S. Photosynthetic electron transfer from reaction center pigment-protein complex in silica nanopores, Langmuir 2010, 26, 1339913406.

Ohmori, H., Nagy, L., Dorogi, M., Terazima, M. Charge stabilization in reaction center protein investigated by optical heterodyne detected transient grating spectroscopy, Eur. Biophys. J. (Biophys. Lett.) 2008, 37, 1167-1174. 
Osváth, S., Maróti, P. Coupling of cytochrome and quinone turnovers in the photocycle of reaction centers from the photosynthetic bacterium Rhodobacter sphaeroides, Biophysical Journal 1996, 73, 972-982.

Paddock, M. L., Feher, G., Okamura, M. Y. Proton Transfer Pathways and Mechanism in Bacterial Reaction Centers, FEBS Lett. 2003, 555, 45-50.

Palestino, G., Legros, R., Agarwal, V., Pérez, E., Gergely, C. Functionalization of nanostructured porous silicon microcavities for glucose oxidase detection, Sensors and Actuators B 2008, 135, 27-34.

Perullinia, M., Mercedes Riverob, M., Jobbágya, M., Mentaberryb, A., Bilmes, A. S. Plant cell proliferation inside an inorganic host, J. Biotechnology 2007, 127, 3, $542-548$.

Rehm, H.-J., Reed, G., Pühler, A., Stadler, P. Biotechnology 11a (EnvironmentalProcesses I-III.) 1996.

Rinyu, L. A primer kinon energetikai változásai a fotoszintetizáló baktériumok reakciócentrumában. Mutáció, késleltetett fluoreszcencia és modell-számítások (Ph.D. disszertáció, SZTE TTIK), 2007.

Rooke, J. C., Léonard, A., Su, B. L. Targeting photobioreactors: Immobilisation of cyanobacteria within porous silica gel using biocompatible methods, Mater. Chem. 2008, 18, 1333-1341.

Saab, M. B., Estephan, E., Cloitre, T., Larroque, C., Gergely, C. Peptide route functionalization of $\mathrm{ZnSe}$ crystals preserves activity and structure of proteins while adsorption, J. Phys. Chem. C 2010, 114, 18509-18515.

Schweitzer, C., Schmidt, R. Physical mechanisms of generation and deactivation of singlet oxygen, Chem. Rev. 2003, 103, 1685-1757. 
Singh, R., Pantarotto, D., McCarthy, D., Chaloin, O., Hoebeke, J., Partidos, C. D., Briand, J. P., Prato, M., Bianco, A., Kostarelos, K. Binding and condensation of plasmid DNA onto functionalized carbon nanotubes: toward the construction of nanotube-based gene delivery vectors, J. Am. Chem. Soc., 2005, 127 (12), 43884396.

Straley, S. C., Parson, W. W., Mauzerall, D. C., Clayton, R. K. Pigment content and molar extinction coefficients of photochemical reaction centers from Rhodopseudomonas Spheroides, Biochimica et Biophysica Acta 1973, 305, 597 609.

Stracke, F. Heupel, M., Thiel, E. Singlet molecular oxygen photosensitized by Rhodamine dyes: Correlation with photophysical properties of the sensitizers, $J$. Photochem. Photobiol. A 1999, 126, 51-58 .

Szabó, T., Magyar, M., Németh, Z., Hernádi, K., Endrődi, B., Bencsik, G., Visy, Cs., Horváth, E., Magrez, A., Forró, L., Nagy, L. Charge stabilization by reaction center protein immobilized to carbon nanotubes functionalized by amine groups and poly(3-thiophene acetic acid) conducting polymer, Phys. Status Solidi B 2012, $12,2386-2389$

Tan, S. C., Crouch, L. I., Mahajan, S., Jones, M. R., Welland, M. E. Tuning the open circuit voltage of photoprotein-based photoelectrochemical cells by manipulation of the vacuum potential of the electrolyte, ACS NANO 2012, 6, 9103-9109.

Tandori, J., Nagy, L., Maróti, P. Semiquinone oscillation as a probe of quinone/herbicide binding in bacterial reaction centers, Photosynthetica 1991, 25, $159-166$.

Tandori, J., Nagy, L., Puskas, A., Droppa, M., Horvath, G., Maróti, P. The IleL229 --> met mutation impairs the quinone binding to the QB-pocket in reaction centers of Rhodobacter Sphaeroides, Photos. Res. 1995, 45, 135-146. 
Tandori, J., Hideg, É., Nagy, L., Maróti, P., Vass, I. Photoinhibition of carotenoidless reaction centers from Rhodobacter sphaeroides by visible light. Effects on protein structure and electron transport, Photosynth. Res. 2001, 70, $175-184$.

Telfer, A., Bishop, S. M., Philips, D., Barber, J. Isolated photosynthetic reaction center of photosystem II as a sensitizer for the formation of singlet oxygen. Detection and quantum yield determination using a chemical trapping technique, J. Biol. Chem. 1994, 269, 13244-13253.

Thompson, C. M., Nieuwoudt, M., Ruminski, A. M., Sailor, M. J., Miskelly, G. M. Electrochemical preparation of pore wall modification gradients across thin porous silicon layers, Langmuir 2010, 26, 7598-7603.

Tiede, D. M., Vázquez, J., Córdova, J., Marone, P. A. Time-resolved electrochromism associated with the formation of quinone anions in the Rhodobacter sphaeroides R26 reaction center, Biochemistry 1996, 35(33), 10763-10775.

Tkachenko, G. V., Tkachenko, V., Abbate, G., Stefano, L. C., Rea, I., Sukhoivanov, I. A. Nematic Liquid Crystal Confined in Electrochemically Etched Porous Silicon, Optical Characterization and Applications in Photonics, New Developments in Liquid Crystals 2009, DOI: 10.5772/9680.

Tsai, Y. C., Li, S. C., Liao, S. W. Electrodeposition of polypyrrole-multiwalled carbon nanotube-glucose oxidase nanobiocomposite film for the detection of glucose, Biosensors \& bioelectronics 2006, 22, 4, 495-500.

Uchoa, A. F., Konx, P. P., Turchielle, R., Seifullina, N. Kh., Baptista, M. S. Singlet oxygen generation in the reaction centers of Rhodobacter sphaeroides, European Biophysics Journal 2008, 37, 843-850.

Velev, O. D., Jede, T. A., Lobo, R. F. Lenhoff, A. M. Porous silica via colloidal crystallization, Nature 1997, 389, 447-448. 
Ventrella, A., Catucci, L., Agostiano, A. Herbicides affect fluorescence and electron transfer activity of spinach chloroplasts, thylakoid membranes and isolated Photosystem II., Bioelectrochemistry 2010, 79, 43-49.

Ventrella, A., Catucci, L., Piletska, E., Piletsky, S., Agostiano, A. Interactions between heavy metals and photosynthetic materials studied by optical techniques, Bioelectrochemistry 2009, 77, 19-25.

Wijnhoven, J. E. G. J., Vos, W. L. Preparation of photonic crystals made of air spheres in titania, Science 1998, 281, 802-804.

Wraight, C. A. Proton and electron in the acceptor quinone complex of photosynthetic reaction centers from Rhodobacter Sphaeroides, Frontiers in Bioscience 2004, 9, 309-337.

Wright, J. D., Sommerdijk, N. Sol-Gel Materials, Chemistry and Applications, Lavoisier Libraire, 2000.

Wu, E. C., Andrew, J. S., Buyanin, A., Kinsella, J. M., Sailor, M. J. Suitability of porous silicon microparticles for the long-term delivery of redox-active therapeutics, Chem. Commun. 2011, 47, 5699-5701.

Xiao, L., Gu, L., Howell, S. B., Sailor, M. J. Porous silicon nanoparticle photosensitizers for singlet oxygen and their phototoxicity against cancer cells, ACS Nano 2011, 5, 3651-3659.

Zhang, X. F., Li, X. The photostability and fluorescence properties of diphenylisobenzofuran, Journal of Luminescence 2011, 131, 2263-2266. 


\section{SUMMARY}

\section{Introduction}

Biological materials developed by nature are extremely efficient and complex systems. It is a real challenge to use them in biohybrid composites and harness all their advantageous properties. This way it is possible to build environmentally friendly biodegradable items like drug delivery systems, biosensors (Oda et al., 2010, Campas et al., 2008; Ventrella et al., 2009, 2010). In addition, it is also probable to use them for special (opto)electronic devices, photoelectric energy conversion or different imaging systems (Velev et al., 1997, Wijnhoven, 1998). Biomaterials are sensitive when they are isolated out of their natural environment, so these applications usually require their integration into biocompatible abiotic matrices. Combining different materials several new possibilities and new advantageous properties have been upcoming.

The photosynthetic conversion of solar energy into chemical energy is one of the most important processes on Earth. Photosynthetic biomaterials have always had special interest in every level of organization of being, from photoactive molecules to whole plant cells. Numerous studies have already been carried out about the application of whole plant cells in artificial systems to achieve different special tasks like biosensors or bioreactors (Campostrini et al., 1996, Carturan et al., 1998, Meunier et al., 2010). In these research works one of the most popular materials is Arabidopsis thaliana as the viability of these plant cells are excellent even after immobilization. So, I used Arabidopsis thaliana cell culture and encapsulated it in a silica matrix with sol-gel method. The main challenge was to fabricate an artificial environment for the cells where they can preserve their cell viability.

Working with photosynthetic organisms the efficiency of our system can be much better if we use only a part of the whole cells, as there are a lot of mechanisms that can cause energy loss during the light harvesting. The first steps of energy conversion in photosynthesis take place in a pigment-protein system called reaction centre (RC). It is really thought-provoking that although its size is only a few nanometers, the present form of life in Earth depends on this protein 
complex. After photoexcitation a charge pair is formed inside the protein. The charge separation and stabilization is connected to protonation and deprotonation of specific amino acids. The efficiency of this system is near to $100 \%$ as every absorbed photon creates a charge pair which is further stabilized within the protein (Allen et al., 1998, Nelson et al., 2009, Kleinfeld et al., 2010, Lu et al., 2005, 2007, Dorogi et al., 2006, Ohmori et al., 2008, Tan et al., 2012).

During my research work I have bound photosynthetic reaction centre to conducting and semiconducting materials by chemical and physical methods. Two different carrier matrices (carbon nanotubes and porous silicon) were used in my experiments because of their exceptional physical characteristics, like biocompatibilitiy, specific surface area, electric and mechanical properties, etc.

For any possible practical application it must be taken into account that some of the excitation energy is captured in triplet states of chlorophylls and transferred easily to triplet oxygen. On one hand, this process can be useful because of the longer life time of the excited state. On the other hand, unuseful due to the damaging effect of the produced singlet oxygen (Uchoa et al., 2008, Arellano et al., 2007). The role of carbon nanotubes in quenching the singlet oxygen after photoexcitation of RC-bionanocomposit was also investigated.

\section{Aims}

1. Immobilization of Arabidopsis thaliana whole plant cells in silica gel matrix using sol-gel process, finding the best properties for this method and characterization of photochemical/-physical properties of the composite.

2. Preparation of bionanocomposites by the chemical or physical binding of bacterial photosynthetic reaction centre purified from Rhodobacter sphaeroides purple bacteria, to the surface of conducting or semiconducting matrix.

2.1. Chemical binding of photosynthetic reaction centre on the surface of amine-functionalized single walled carbon nanotube (SWCNT). 
Morphological (AFM, SEM) and functional (flash photolysis) characterization of the prepared RC/SWCNT complexes.

2.2. Chemical and physical binding of photosynthetic reaction centre on the surface of porous silicon (PSi), morphological (SEM, EDX) characterization of the composites, detection of the different binding methods' efficiency (Fourier Transfrom Infrared Spectroscopy) and the measurement of the photoactivity of the complexes after different binding methods (flashphotolysis measurements).

\section{Materials and methods}

\section{Preparation of biological samples and biocomposites}

\section{$\underline{\text { Plant Cell Culture }}$}

Suspension-cultured Arabidopsis thaliana cells derived from leaves of A. thaliana strain L-MM1 ecotype Landberg erecta were cultivated in Murashige and Skoog medium (4.43 g/l, pH 5.7) supplemented with sucrose $(30 \mathrm{~g} / \mathrm{l}), 0.05 \mu \mathrm{g} / \mathrm{ml}$ of kinetin, and $0.5 \mu \mathrm{g} / \mathrm{ml}$ of NAA (naphtalene-acetate; Meunier et al., 2010).

Photosynthetic Reaction Centre Preparation

$R b$. sphaeroides R-26 cells were grown photoheterotrophically. RCs were prepared by LDAO (N,Ndimethyldodecylamine-N-oxide, Fluka) solubilization and purified by ammonium sulfate precipitation, followed by DEAE Sephacell (Sigma) anion-exchange chromatography (Nagy et al., 1991).

\section{Carbon Nanotube (CNT) Preparation}

The purification of the carbon nanotubes was done by wet oxidation method: 100 g pure HiPco single walled carbon nanotubes (SWCNT) was oxidized in the mixture of $60 \mathrm{ml} 30 \% \mathrm{H}_{2} \mathrm{O}_{2}$ and $110 \mathrm{ml} 22 \% \mathrm{HCl}$. The solution was under continuous reflux for $9 \mathrm{~h}$ at $70{ }^{\circ} \mathrm{C}$. After that the temperature was adjust to $25^{\circ} \mathrm{C}$ and the SWCNTs were filtered and washed with distilled water to reach $\mathrm{pH} 7$. Finally they were dried at $120{ }^{\circ} \mathrm{C}$ for 30 minutes (Dorogi et al., 2006). 


\section{Porous silicon (PSi) Preparation}

PSi wafers were prepared by a wet electrochemical etching using highly borondoped p-type silicon wafers (thickness $500-550 \mu \mathrm{m}$ ) with a $0.002-0.004 \mathrm{ohm} / \mathrm{cm}$ specific resistivity and with a crystallographic orientation of (100). The microcavity structures were fabricated with the configuration of (HL) $\times 5 \mathrm{HH}(\mathrm{LH}) \times 5$ where $\mathrm{H}$ and $\mathrm{L}$ represent high and low porosity layers, respectively. As the optical thickness of each layer was kept at $\lambda / 4$ (with $\lambda=700$ $\mathrm{nm}$ ), the presence of two successive layers of high porosity in the middle creates a cavity mode with an optical thickness of $\lambda / 2$. To ensure good macromolecular penetration, the multilayers were prepared by assuring higher porosity for the first layer (Agarwal et al., 2003, 2004).

\section{Composite preparation}

\section{Plant Cell Encapsulation}

Anaqueous sol-gel route was used to encapsulate fragile plant cells into pure and organically modified silica matrices. MTGS (methyl triglicerol silane) was employed to synthetise the organically modified hybrid material. This compound is synthetised by mixing MTMS (100 mM, Fluka, >98\%) and Glycerol (300 mM, Fluka, 99.5\%). Sodium silicate solution was made from $\mathrm{Na}_{2} \mathrm{SiO}_{3}$ (Mercks). Resin (Acros) was rinsed with acid water $\mathrm{pH}$ 0.5-1 (1 M HCl Sigma) and after freezing, it was mixed with the sodium silicate solution and then a clear sol was recovered after filtration. Organically modified silane stock solution was obtained by mixing the solution described above, different concentrations of MTGS, $\mathrm{NaCl}$ and $\mathrm{KOH}$ solution and plant cell solution (20 V\%). During the gel preparation the $\mathrm{pH}$ is the determining factor. First the $\mathrm{pH}$ is acidic so before adding the plant cell it has to be adjusted to 5.7 .

\section{Reaction Centre/Carbon Nanotube Composite Preparation}

RC was bound to the amine functionalized SWCNTs using glutaraldehyde (GTA) homobifunctional crosslinker molecule. $50 \mu \mathrm{l}$ GTA was mixed with $800 \mu \mathrm{l}$ SWCNT suspension and mixed for 10 minutes at $400 \mathrm{rpm}$. The unbound GTA was removed by dialysis ( 20 minutes, phosphate puffer, pH 6.5). $100 \mu \mathrm{RC}(\mathrm{c}=64 \mu \mathrm{M})$ was put into this solution and dialised, again, for $2 \mathrm{~h}$ in phosphate buffer ( $\mathrm{pH}$ 7.0). The unbound RCs were removed by series of washing and centrifugation in 
phoshpate buffer ( $\mathrm{pH} 7.0,0.03 \%$ LDAO). The suspension was dried on a glass surface.

$\underline{\text { Reaction Centre/Porous Silicon Preparation }}$

RC was bound to PSi in two different ways. The first method involved a three-step conjugation protocol. The PSi surface was first functionalized using the amine group of 3-aminopropyl-triethoxysilane (APTES), followed by the binding of glutaraldehyde (GTA) as an amine-targeted homobifunctional cross-linker. Finally, the RC was bound to GTA through its surface-accessible lysine side chains.

In the second method, the RC was bound to PSi through a 12-mer peptide (SPGLSLVSHMQT) previously elaborated as a specific linker for the used p-type PSi surfaces. Briefly, the deoxidized (by $\mathrm{HCl}$ ), freshly etched PSi sample was exposed to the peptide solution (20 $\mu \mathrm{M}$ in PBST, (PBS buffer, 0.1\% Tween 20)) for $2 \mathrm{~h}$. The unbound peptide was washed away with PBST. To bind the RC, drops of the protein solution (in $10 \mathrm{mM}$ TRIS, $0.03 \%$ LDAO, $\mathrm{pH} 8.0$ ) were placed on the sample surface for $90 \mathrm{~min}$, followed by washing with PBS buffer.

\section{Investigation methods}

\section{Biological Activity and Viability of Plant Cells}

The physiological functions of entrapped cells were assessed by monitoring the oxygen consumption in a Clark cell vessel (Oxy-lab manufactured by Hansatech Instruments). Typically, $500 \mathrm{mg}$ of monolithic gel pieces were added to $1 \mathrm{ml}$ of Murashige and Skoog medium (MS medium, Murashie and Skoog, 1962). The activity of the plant cell suspension was measured just before immobilization and was taken as the reference (100\%). Cell viability was determined by gently crushing hybrid gels on the surface of a MS agar medium. The ability of encapsulated cells to grow and form so-called callus tissues (unorganized plant tissues) was used as an indicator of cell viability.

\section{Scanning Electron Microscopy}

Scanning electron microscopy (SEM) was performed with a Hitachi S-4700 type II FE-SEM equipped with a cold field emission gun operating in the range of 5$15 \mathrm{kV}$. The samples were mounted on a conductive carbon tape and sputter coated with a thin $\mathrm{Au} / \mathrm{Pd}$ layer in an $\mathrm{Ar}$ atmosphere prior to the measurement. To 
characterize the element distribution within the PSi structure, energy-dispersive Xray analyses (EDX) were also performed using a RONTEC X Flash Detector 3001 with a silicon drift detector (SDD).

\section{$\underline{\text { Specular Reflectometry }}$}

Reflectivity spectra were recorded with a Bruker 66 V Fourier Transform Infrared spectrometer using the Bruker A $510,11^{\circ}$ specular reflection unit. The PSi samples were illuminated with the tungsten source, and the reflected beam was detected with the silicon diode detector. The resulting spectrum was captured in the range of $25000-9000 \mathrm{~cm}^{-1}$ after each modification step of the porous silicon. It was the average of 100 scans and had a spectral resolution of $2 \mathrm{~cm}^{-1}$ (Estephan et al., 2011, Thompson et al., 2010).

\section{Optical Spectroscopy}

Flash-induced absorption changes were measured at 430 and $860 \mathrm{~nm}$ by the single-beam kinetic spectrophotometer of local design (Tandori et al., 1995). In the case of the PSi samples there was a geometrical modification to allow its operation in reflection mode instead of transmission mode. In this case the measuring light beam was incident on the surface of the RC functionalized PSi sample at $45^{\circ}$ and reflected toward the photomultiplier tube detector (Hamamatsu R928). For activation, the beam of a Xe flash lamp (EG\&G FX200, $\mathrm{t}_{1 / 2}=8.5 \mu \mathrm{s}$ ) was projected perpendicularly on the sample surface through an optical fiber. At $860 \mathrm{~nm}$, the redox state of the $\mathrm{P} / \mathrm{P}^{+}$couple can be monitored without a substantial contribution by the other cofactors of the RC. The oxidation of horse heart cytochrome c (Sigma) by RCs bound to PSi was measured at $550 \mathrm{~nm}$ in transmission mode (Kleinfeld et al., 1984, Osváth et al., 1996). The PSi sample containing the bound RCs was placed in a $1 \mathrm{~cm} \times 1 \mathrm{~cm}$ spectroscopic cuvette containing buffer solution (10 mM TRIS, $100 \mathrm{mM} \mathrm{NaCl,} \mathrm{0.03 \%} \mathrm{LDAO,} \mathrm{pH} \mathrm{8.0)}$ next to its rear wall facing the Xe flash beam, thereby avoiding the perpendicular measuring light beam. A series of actinic Xe flashes were applied with a repetition rate of $1 \mathrm{~Hz}$. The amount of cytochrome c oxidized by the RCs was determined using the difference in the extinction coefficient $\varepsilon_{\text {red }}-\varepsilon_{\mathrm{ox}}=21.1 \pm 0.4 \mathrm{mM}^{-1} \mathrm{~cm}^{-1}$. Cytochrome c was reduced by ascorbate before the experiments. For the reconstitution of the quinone electron-acceptor side, water-soluble $\mathrm{UQ}_{0}(2,3-$ methoxy-5-methyl-1,4-ubiquinone, Sigma) was used. 


\section{New Results}

1. I managed to immobilize Arabidopsis thaliana plant whole cells in silica gel matrix using sol-gel method. The cells preserved their activity even after immobilization and they were able to produce oxygen.

2. I prepared bio-nanocomposites by the chemical or physical immobilization of photosynthetic reaction centre (RC) purified from Rhodobacter sphaeroides purple bacteria. The carrier matrices were conducting or semiconducting materials.

2.1. I bound photosynthetic reaction centre chemically to amine-functionalized single walled carbon nanotubes (SWCNT) using glutaraldehyde crosslinker molecule.

a) Morphological characterization (AFM, SEM) showed that there is a monolayer RC coverage on the SWCNT surface.

b) According to the flash-photolysis measurements the immobilized RCs keep their photoactivity even after the binding procedure.

c) After photoexcitation the life time of the uprising oxidized chlorophyll dimer $\left(\mathrm{P}^{+}\right)$increases significantly in the complex $(\tau=1200 \mathrm{~ms}$ and $3100 \mathrm{~ms}$ in solution, detergent micelle and bound to single walled carbon nanotube).

d) The increase of the life time can be explained by the effect of the carbon nanotubes. SWCNT can have effect on the stabilization of the charge pair inside the RC.

2.2. I bound photosynthetic reaction centre to porous silicon wafers chemically with glutaraldehyde crosslinker molecule, and supported with a specific peptide molecule as well.

a) Morphological characterization (AFM, SEM) and optical reflection measurements showed that the RCs were bound successfully into the PSi's porous and preserved their photoactivity after both binding procedure. 
b) RC binding had a saturation kinetics that could be characterized by the shift of the specific modus in the reflection spectra.

c) In both case, the half of the saturation maximum was reached at about $3 \mu \mathrm{M} \mathrm{RC}$ concentration, however the shift of the reflection spectra was always bigger with the "peptide method" $(\Delta \lambda \max =59( \pm 5)$ and $38( \pm 8) \mathrm{nm}$ using the "peptide" and "GTA method")

d) Flash photolysis measurements showed that the RC remained active after the immobilization on the PSi surface. After photoexitation the relaxation time of the oxidized chlorophyll dimer $\left(\mathrm{P}^{+}\right)$had one component in the case of the "peptide method" ( $\tau=27 \mathrm{~ms}$ ), since using the "GTA method" there were two components $\left(\tau_{1}=14 \mathrm{~ms}, \tau_{2}=230 \mathrm{~ms}\right)$.

e) After series of saturating flash excitation cytochrome oxidation can be measured. It was possible to block this mechanism by using terbutrin indicating that the donor and acceptor sides of the RC are accessible after immobilization.

\section{References}

Agarwal, V., del Río, J. A. Tailoring the photonic band gap of a porous silicon dielectric mirror, Appl. Phys. Lett. 2003, 82, 1512-1514.

Agarwal, V., del Río, J. A., Zamfirescu, G. M., Kavokin, A., Coquillat, D., Scalbert, D., Vladimirova, M., Gil, B. Photon bloch oscillations in porous silicon optical superlat-tices, Phys. Rev. Lett. 2004, 92, DOI: 10.1103/PhysRevLett.92.097401.

Allen, J. P., Williams, J. C. Photosynthetic reaction centers, FEBS Lett. 1998, 438, 5-9.

Arellano, J. B., Yousef, Y. A., Melo, T. B., Mohamad, S. B. B., Cogdel, R. J., Naqvi, K. R. Formation and geminate quenching of singlet oxygen in purple bacterial reaction cen-ter, Journal of Photochemistry and Photobiology B: Biology 2007, 87, 105-112. 
Campas, M., Carpentier, R., Rouillon, R. Plant tissue-and photosynthesis-based biosensors, Biotechnol. Adv. 2008, 26, 370-378.

Campostrini, R., Carturan, G., Caniato, R., Piovan, A., Filippini, R., Innocenti, G., Cappelletti, E. M. J. Immobilization of plant cells in hybrid sol-gel materials, SolGel Sci. Technol. 1996, 7, 87-97.

Carturan, G., Dal Monte, R., Pressi, G., Secondin, S., Verza, P. J. Production of valuable drugs from plant cells immobilized by hybrid sol-gel $\mathrm{SiO}_{2}$, Sol-Gel Sci. Technol. 1998, 13, 273-276.

Dorogi, M., Bálint, Z., Mikó, C., Vileno, B., Milas, M., Hernádi, K., Forró, L., Váró, G., Nagy, L. Stabilization effect of single walled carbon nanotubes on the functioning of photosynthetic reaction centers, J. Phys. Chem. B. 2006, 110, 21473-21479.

Estephan, E., Saab, M.-B., Agarwal, V., Cuisinier, F. J. G., Larroque, C., Gergely, C. Peptides for the biofunctionalization of silicon for use in optical sensing with porous silicon microcavities, Adv. Funct. Mater. 2011, 21, 2003-2011.

Kleinfeld, D.; Okaamura, M. Y.; Feher, G. Electron transfer in reaction centers of Rhosopseudomonas Sphaeroides. I. Determination of the charge recombination pathway of $\mathrm{D}^{+} \mathrm{Q}_{\mathrm{A}} \mathrm{Q}_{\mathrm{B}}{ }^{-}$and free energy and kinetic relations between $\mathrm{Q}_{\mathrm{A}}{ }^{-} \mathrm{Q}_{\mathrm{B}}$ and $\mathrm{Q}_{\mathrm{A}} \mathrm{Q}_{\mathrm{B}}{ }^{-}$, Biochem. Biophys. Acta 1984, 766, 126-140.

Lu, Y., Xu, Y., Liu, B., Kong, J. Photosynthetic reaction center functionalized nano-composite films: Effective strategies for probing and exploiting the photoinduced electron transfer of photosensitive membrane protein, Biosens. Bioelectron. 2007, 22, 1173-1185.

Lu, Y., Yuan, M., Liu, Y., Tu, B., Xu, C., Liu, B., Zhao, D., Kong, J. Photoelectric performance of bacteria photosynthetic proteins entrapped on tailored mesoporous WO3-TiO2 films, Langmuir 2005, 21(9), 4071-4076. 
Meunier, C. F., Dandoy, P., Su, B. L. Encapsulation of cells within silica matrixes: Towards a new advance in the conception of living hybrid materials, Journal of Colloid and Interface Sicence 2010, 342, 2, 211-224.

Murashige, T., Skoog, T. A revised medium for rapid growth and bio assays with tobacco tissue cultures, Physiol. Plant 1962, 15. 473-497.

Nagy, L., Puskás, Á., Tandori, J., Droppa, M., Horváth, G. Effect of DCMU on photosynthetic purple bacteria, Photosynthetica 1991, 25, 167-171.

Nelson, A., Cox, D., Lehninger, M. Principles of Biochemistry W H Freeman \& Co. 2009.

Oda, I., Iwaki, M., Fujita, D., Tsutsui, Y., Ishizaka, S., Dewa, M., Nango, M., Kajino, T., Fukushima, Y., Itoh, S. Photosynthetic electron transfer from reaction center pigment-protein complex in silica nanopores, Langmuir 2010, 26, 1339913406.

Ohmori, H., Nagy, L., Dorogi, M., Terazima, M. Charge stabilization in reaction center protein investigated by optical heterodyne detected transient grating spectroscopy, Eur. Biophys. J. (Biophys. Lett.) 2008, 37, 1167-1174.

Osváth, S., Maróti, P. Coupling of cytochrome and quinone turnovers in the photocycle of reaction centers from the photosynthetic bacterium Rhodobacter sphaeroides, Biophysical Journal 1996, 73, 972-982.

Tan, S. C., Crouch, L. I., Mahajan, S., Jones, M. R., Welland, M. E. Tuning the open circuit voltage of photoprotein-based photoelectrochemical cells by manipulation of the vacuum potential of the electrolyte, ACS NANO 2012, 6, 9103-9109.

Tandori, J., Nagy, L., Puskas, A., Droppa, M., Horvath, G., Maróti, P. The IleL229 --> met mutation impairs the quinone binding to the QB-pocket in reaction centers of Rhodobacter Sphaeroides, Photos. Res. 1995, 45, 135-146. 
Thompson, C. M., Nieuwoudt, M., Ruminski, A. M., Sailor, M. J., Miskelly, G. M. Electrochemical preparation of pore wall modification gradients across thin porous silicon layers, Langmuir 2010, 26, 7598-7603.

Uchoa, A. F., Konx, P. P., Turchielle, R., Seifullina, N. Kh., Baptista, M. S. Singlet oxygen generation in the reaction centers of Rhodobacter sphaeroides, European Biophysics Journal 2008, 37, 843-850.

Velev, O. D., Jede, T. A., Lobo, R. F. Lenhoff, A. M. Porous silica via colloidal crystallization, Nature 1997, 389, 447.

Ventrella, A., Catucci, L., Agostiano, A. Herbicides affect fluorescence and electron transfer activity of spinach chloroplasts, thylakoid membranes and isolated Photosystem II., Bioelectrochemistry 2010, 79, 43-49.

Ventrella, A., Catucci, L., Piletska, E., Piletsky, S., Agostiano, A. Interactions between heavy metals and photosynthetic materials studied by optical techniques, Bioelectrochemistry 2009, 77, 19-25.

Wijnhoven, J. E. G. J., Vos, W. L. Preparation of photonic crystals made of air spheres in titania, Science 1998, 281, 802-804. 